\title{
Advances in Healing-on-Demand Polymers and Polymer Composites
}

\section{Pengfei Zhang ${ }^{1}$ and Guoqiang $\mathrm{Li}^{1,2, *}$}

${ }^{1}$ Department of Mechanical \& Industrial Engineering, Louisiana State University, Baton Rouge,

\author{
LA 70803, USA \\ ${ }^{2}$ Department of Mechanical Engineering, Southern University, Baton Rouge, LA 70813, USA
}

\begin{abstract}
Healing-on-demand materials exhibit the capability to close cracks and heal the closed/narrowed cracks when needed and to recover functionality using intrinsic or extrinsic resources. In this review, advances in healing-on-demand polymers and polymer composites in the past decade are reviewed, covering different schemes and technologies used to trigger crack closure and to heal molecularly. A balanced review on non-load-bearing polymers and polymer composites as well as load-carrying polymers and polymer composites is presented. The progress in self-healing polymers and polymer composites has been well discussed recently in the literatures. In this review, therefore, less attention has been paid on what has been widely reported; we primarily focus on healing-on-demand materials concerned with large volume damage healing by a closethen-heal $(\mathrm{CTH})$ strategy. The healing-on-demand material by the $\mathrm{CTH}$ approach undergoes a process of crack closure, followed by crack healing with healing agents. Healing theories, including those within the continuum damage mechanics framework, and healing efficiency evaluations are also reviewed. Perspectives on future development in this emerging research area are discussed.
\end{abstract}

Keywords: Healing-on-demand; Polymers; Polymer composites; Biomimetic; Close-then-heal; Shape memory.

*Corresponding author: lguoqi1@1su.edu; Tel.: 001-225-578-5302. 


\section{Table of Contents}

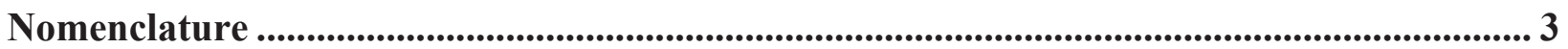

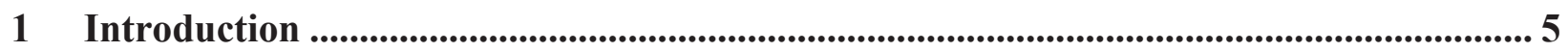

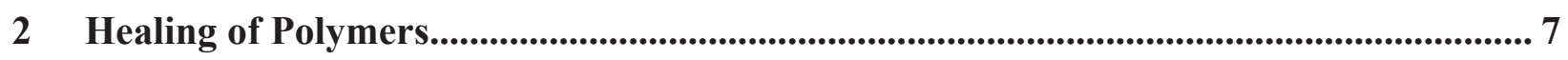

2.1 Crack Initiation and Surface Approaching ............................................................ 9

2.2 Crack Healing Mechanisms .............................................................................. 10

3 Healing of Polymer Composites .............................................................................. 15

3.1 Capsulated Polymer Composites.......................................................................... 15

3.2 Hollow-fiber Reinforced Polymer Composites..................................................... 17

3.3 Vascular Networks based Healing-on-Demand Polymer Composites......................... 17

3.4 Heling in Layer-by-Layer Coating/Film ............................................................. 19

3.5 Solid-state Healant Embedded in Polymer Composites............................................. 20

4 Close-Then-Heal Strategy for Polymer Composites....................................................... 20

4.1 Shape Memory Assisted Crack Healing................................................................. 22

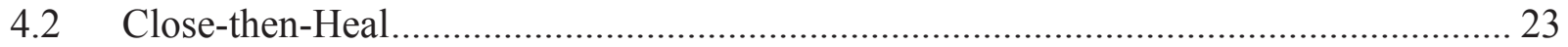

4.3 Healing Theories and Healing Efficiency Evaluation.............................................. 32

5 Conclusions and Future Perspectives .......................................................................... 39

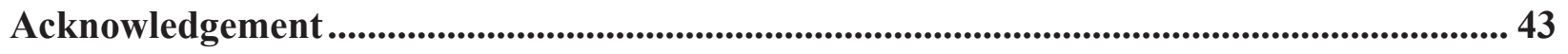

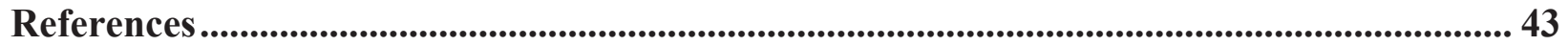




\section{Nomenclature}

\begin{tabular}{|c|c|}
\hline $\begin{array}{l}\text { A6ACA } \\
\beta-C D\end{array}$ & $\begin{array}{l}\text { acryloyl-6-aminocaproic acid } \\
\beta \text {-cyclodextrin }\end{array}$ \\
\hline BDMA & benzyl dimethylamine \\
\hline $\begin{array}{l}\text { BIE } \\
\text { bPEI }\end{array}$ & $\begin{array}{l}\text { benzoin isobutyl ether } \\
\text { branched poly(ethylenimine) }\end{array}$ \\
\hline $\begin{array}{l}\text { BPO } \\
\text { CDTE }\end{array}$ & $\begin{array}{l}\text { benzoyl peroxide } \\
\text { cyanodithioester }\end{array}$ \\
\hline CoPECs & compact polyelectrolyte complexes \\
\hline $\mathrm{Cp}$ & cyclopentadiene \\
\hline CuAAC & copper (I)-catalyzed alkyne-azide cycloaddition \\
\hline $\mathrm{DA}$ & Diels-Alder reaction \\
\hline DABBF & diarylbibenzofuranone \\
\hline DB24C8 & dibenzo[24]crown- 8 \\
\hline DBTL & di- $n$-butyltin dilaurate \\
\hline DCPD & dicyclopentadiene \\
\hline DHEOMC & derivative 5,7-bis(2-hydroxyethoxy)-4-methylcoumarin \\
\hline DNA & Deoxyribonucleic acid \\
\hline DOPA & 3,4-dihydroxyphenylalanine \\
\hline DTHP & diglycidyl tetrahydro-o-phthalate \\
\hline EMNa & sodium salt of poly(ethyelene-co-methacrylic acid) \\
\hline EMZn & zinc salt of poly(ehtyelene-co-methacrylic acid) \\
\hline ENR & epoxidized natural rubber \\
\hline GMA & glycidyl methacrylate \\
\hline HGF & hollow glass fiber \\
\hline HOPDMS & hydroxyl end-functionalized polydimethylsiloxane \\
\hline HPA & 2-hydroxypropyl acrylate \\
\hline HPF & hollow polymer fiber \\
\hline IPDI & isophorone diisocyanate \\
\hline LMWOs & low-molecular-weight organogelators \\
\hline $\mathrm{M}_{2}$ & 1,8-Bis(maleimido)-triethylene glycol \\
\hline MAT & methacryloxypropyl-terminated \\
\hline NHCs & N-heterocyclic carbens \\
\hline $\mathrm{PA}$ & polyacrylate \\
\hline PAA & poly(acrylic acid) \\
\hline pAA-CDs & poly(acrylic acid) modified with cyclodextrins \\
\hline $\mathrm{pAA}-\mathrm{Fc}$ & poly(acrylic acid) modified with ferrocene \\
\hline PAH & poly(allylamine hydrochloride) \\
\hline PCL & poly( $\varepsilon$-caprolactone $)$ \\
\hline PDMAA & poly(N,N-dimethylacrylamide) \\
\hline PDMS & poly(dimethylsiloxane) \\
\hline PEG & poly(ethylene glycol) \\
\hline PEI & poly(ethyleneimine) \\
\hline PEMAA & poly(ethylene-co-methacrylic acid) \\
\hline
\end{tabular}




$\begin{array}{ll}\text { PFS } & \text { poly(2,5-furandimethylene succinate) } \\ \text { PIB } & \text { poly(isobutylene) } \\ \text { PIE } & \text { isonicotinate-functionalized polyesters } \\ \text { PK } & \text { polyketones } \\ \text { PLA } & \text { poly(lactic acid) } \\ \text { PMMA } & \text { poly(methyl methacrylate) } \\ \text { PNIPA } & \text { poly(N-isopropylacrylamide) } \\ \text { PISP } & \text { polyisoprene } \\ \text { POM } & \text { polyoxometalates } \\ \text { PVAc } & \text { poly(vinyl acetate) } \\ \text { PVA } & \text { poly(vinyl alcohol) } \\ \text { PS } & \text { polystyrene } \\ \text { PSS } & \text { poly(styrene sulfonate) } \\ \text { rDA } & \text { reversible Diels-Alder reaction } \\ \text { ROMP } & \text { ring-opening metathesis polymerization } \\ \text { SMA } & \text { shape memory alloy } \\ \text { SMP } & \text { shape memory polymer } \\ \text { TDCB } & \text { tapered double cantilever beam } \\ \text { TDI } & \text { 2,4-toluene diisocyanate } \\ \text { TDS } & \text { thiuram disulfide } \\ \text { TfOH } & \text { Trifluoromethanesulfonic acid } \\ \text { TPU } & \text { thermoplastic polyurethane } \\ \text { TTC } & \text { trithiocarbonate } \\ \text { UPy } & \text { ureidopyrimidinone } \\ \text { VI } & \text { N-vinylimidazole } \\ & \end{array}$




\section{Introduction}

With the popular use of polymer and polymer composites in industry, damage and fracture within these materials are inevitable [1-5]. Both expected loading such as fatigue load, and incidental loading such as foreign object impact, can lead to serious shortening of service life. Various efforts have been made over the past decades to improve the durability of polymer and polymer composites by designing new materials or developing crack-healing techniques. Bioinspiration has played an important role in developing new crack-healing strategies [6].

The history and evolution of bio-inspired materials and damage-healing techniques have been examined in a number of published reviews, patents, and books [6-50]. Pioneer work mainly focused on the self-healing concept in thermoplastic and thermoset polymers and/or polymer composites through extrinsic or intrinsic resources, as well as the design and generic principles for self-healing systems. These systems include thermosetting polymers, thermoplastic polymers, composite materials, metallic systems, ceramics and ceramic coatings [51], and concrete [52-54]. Self-healing materials by nanotechnology was also developed [55-58]. There is no doubt that the previous endeavors have greatly advanced understanding of the self-healing abilities of polymers and polymer composites, or at least created a sense of what-to-do and whatnot-to-do when designing a crack healing system. However, due to the fast development in this emerging field, there is a need to review these new developments within the framework of healing-on-demand polymers and polymer composites.

Here, we define a healing-on-demand material as one within which a crack, due to mechanical damage or degradation, may be closed and healed in time and in-situ, when the crack is detected or sensed by internal or external means. In other words, when needed, a healing-ondemand material exhibits the capability to permit crack closure and healing under in-service conditions, and to recover functionality using intrinsic or extrinsic resources. In this sense, 
healing-on-demand does not necessarily mean completely autonomous healing or "self-healing". It means that with some intervention such as bringing fracture surfaces in contact, heating, etc., healing can be triggered and proceed without additional intervention. For example, fractured polymer panels may not be able to heal themselves without external help to bring fracture surfaces into contact, regardless of intrinsic healing (without healing agent) or extrinsic healing (with healing agent). Within this definition, some healing schemes, usually not reviewed indepth within the "self-healing" literature, belong to the broader framework of healing-on-demand. Actually, as indicated by Li [47], healing-on-demand may be more appropriate in describing inservice healable materials, because in real world structures, for example a panel under fixed boundary condition and/or under external loading, some help or intervention, although perhaps minimal, is almost always needed to heal wide-opened cracks or large damage volumes.

Fig. 1 shows a concept of healing-on-demand materials, through which inspection and maintenance techniques have been developed to prolong service life of engineering materials. We believe that there is a need for distinction between materials scientists and engineers with respect to self-healing. Five stages of crack healing have been proposed for healing through physical molecular entanglement by Wool and O'Connor [59]. They are (i) surface rearrangement, (ii) surface approach, (iii) wetting, (iv) diffusion, and (v) randomization. For healing through chemical bond interaction, there are four stages, which are (i) surface rearrangement, (ii) surface approach, (iii) chemical reaction, and (iv) dynamic equilibrium. In general, materials scientists are mainly concerned with surface rearrangement, wetting, diffusion or chemical reaction, and randomization or dynamic equilibrium, i.e., reestablishment of physical entanglements or chemical bonds. The stage of surface approach does not cause enough attention. In the lab, fractured specimens are usually brought into contact manually before healing starts. As indicated by Wool [7], and echoed by Binder [48] and Li [47], this manual operation 
represents the largest challenge in the real world applications. From the point of view of engineers, one could not bring a fractured skin panel together by hand in a Boeing aircraft and may not bring a fractured specimen together manually if the boundary of the specimen is fixed [47]. However, crack healing cannot occur without external help to bring the fracture surfaces in contact. Therefore, engineering applications face additional challenge to self-healing materials. We believe that it is time to consider the practical constraint of how to bring the fracture surfaces in contact.

\section{[Insert Figure 1 here]}

In this review, we discuss the potential challenges and opportunities from the point of view of engineering applications. We focus mainly on the crack closing and healing principles for polymers and polymer composites that have emerged over the past decade. Especially, healing-on-demand load-carrying polymer composites and shape memory polymer based crack healing structural composites, which have not been a focus in previous reviews, are discussed in more detail and depth in this review. The close-then-heal strategy, which has been demonstrated by shape memory polymer matrix, shape memory polymer fiber, and polymeric artificial muscle in healing large volume damage for functionality restorations, will be reviewed. The associated healing theories and healing efficiency evaluations will also be reviewed.

\section{$2 \quad$ Healing of Polymers}

Polymers used in industrial applications are designed with a specific service life. Loss of structural capacity or functionality can occur because of incidental damage or degradation over time. It will be a tragedy if polymers fail within their designed lifespan. In order to maintain their service life even after structural damage, polymeric materials have been designed to have the ability to heal themselves on-demand. The study of healing-on-demand polymers, in general, is 
continuously progressing. More exciting discoveries in this area are expected as numerous studies are evolving.

According to the published literatures, the methods for triggering healing-on-demand in polymers include extrinsic stimuli such as $\mathrm{pH}$ [60-64], salt [65], thermal treatment [66-74], water $[75,76]$, light [77-83], sonication [84], and electrical treatment [85]. The intrinsic healing mechanisms include labile bonds [86-91], fusion [92], reversible dissociation-association [93, 94], host-guest interaction [95, 96], metallo/ligand complexation [97], and dynamic covalent bonds [98, 99]. In some cases [62, 66-70, 72, 73, 82, 89], both extrinsic and intrinsic stimuli are involved.

Crack healing polymers have been well reported and summarized by pioneer works; however, in this review, we will focus primarily on the crack approaching methods as well as the damage healing mechanisms. As given in Table 1, the healing-on-demand polymers published since 2007 are summarized based on damage type, crack approaching method, healing mechanism, healing measurement, efficiency, repeatability, healing condition, and healing time. Not all reported research works are included in the table. We only include those that have clear descriptions on crack approaching method and damage healing mechanism so that comparisons can be made. The crack modes, crack approaching methods, and healing mechanisms under ondemand conditions will be mainly discussed based on the summarization in Table 1.

[Insert Table 1 here]

\subsection{Crack Initiation and Surface Approaching}

As shown in Fig. 1, the need for healing is triggered by damage or cracking. Cracking in materials can be initiated by various internal and external means. Fig. 2 shows the types of crack initiation modes based on the summarization in Table 1. For example, ballistic impact could 
create shear plug through the thickness if the impact energy is sufficient or random cracks on the back face if the energy is insufficient. The hole or cracks can be patched due to the elastic spring back such as ionomers [100-104]. Razor cut could initiate a deep cut or even cut materials into two halves. The crack is usually closed by bringing the two halves together manually [83, 107 , 119]. Sawing is another type of cut similar to razor cut $[100,101]$. An accidental damage might result in a random microcrack or structural-scale wide-opened crack depending on the impact energy or damage location [62]. There is no need to bring fractured surfaces together for the scratch damage since the name implies that only scratch marks are created on polymer material surfaces. These scratches may close due to swelling when being submersed into a solution, or close with the shape memory effect when exposed to triggering factors (e.g., UV light, thermal treatment) [81, 123-125]. The polymer materials under compression suffer from buckling and can ultimately fracture. A crack might propagate to a large size if a precrack is introduced to the body prior to buckling [71]. It can be closed through elastic recovery but if a fracture occurs, it is a challenge to heal it. Tensile stretch might result in different damage modes [126]. The mode investigated includes breaking the specimen into two halves $[83,99,110]$. The fracture surfaces were brought into contact to march towards each other manually prior to the healing process. The crack initiated by bending can be closed due to elastic recovery; for wider cracks, they can be closed with the help of compression to push the cracks into contact after the removal of external bending load $[67,68]$.

Although all the cracks in Table 1 are created by external means, they may not be predictable in real world structures such as those under impact load; on the other hand, the crack propagation is somewhat predictable. This gives us an opportunity to close or fill in the cracks by bringing fracture surfaces into contact. Because manually bringing fracture surfaces into contact is very difficult in real world load-bearing structures, the true challenge in self-healing of load 
carrying structures is how to bring the fractured materials in contact, regardless of visible crack on the surface or nonvisible crack within the body of the material.

\section{[Insert Figure 2 here]}

\subsection{Crack Healing Mechanisms}

For all polymers, crack healing follows a two-stage process. On-demand fracture surface approaching is the first stage. In the second stage, healing through physical or chemical means is performed on the surfaces in proximity or in-contact. The crack healing mechanisms have been well assessed by recent review papers and books on self-healing polymers $[21,47,50,127,128]$. To avoid overlaps, we will briefly review and summarize the healing mechanisms based on the categorization in Fig. 3. The mechanisms are categorized into two groups, physical molecular interdiffusion and chemical bond interaction, which is further subdivided into covalent and noncovalent bond interactions, and intermolecular force.

\section{[Insert Figure 3 here]}

\subsubsection{Molecular Interdiffusion}

Polymers can regain their mechanical functionalities through physical interaction (e.g., molecular interdiffusion). Continued interdiffusion, randomization, and long-term relaxation of the polymer chains are required in order to achieve optimal healing performance. There are several factors that can affect the crack healing performance, such as molecular reptation time, healing temperature, co-surfactant effect, and concentration. For example, sodium-chloride $(\mathrm{NaCl})$ has been used as an initiator for increasing the mobility of the chain segments with the aim at accelerating damage healing process. In order to make the healing faster and more complete, compact polyelectrolyte complexes (CoPECs) were prepared by mixing solutions of PAA and PAH, and compacting by ultracentrifugation in the presence of $\mathrm{NaCl}[65,129]$. It 
showed that the CoPECs healed the fracture surfaces when they were brought into contact for 15 min in a salt concentration of $2.5 \mathrm{M} \mathrm{NaCl}$, as presented in Fig. 4. The healing behaviors of the compounds indicate that the healed sample strength depends on the contact time and $\mathrm{NaCl}$ concentration. With increasing salt concentration, the mobility of the chain segments increases; and the more the mobile segments, the faster the chains diffuse and the faster the fracture surfaces heal.

\section{[Insert Figure 4 here]}

\subsubsection{Reversible Covalent Bond}

Making covalent links reversible is one of the strategies to heal cracks and prolong service life of polymers. The reversible bonds allow dynamic bond reactions between covalent links by maintaining constant the total number of network links and average functionality of polymers. Some chemical covalent bond reactions for crack healing applications are presented in Table 2. The reversible covalent bonds have the potential to heal damage-induced cracks in thermoset by restoring mechanical functionalities under on-demand thermal or water stimuli [130-132]. For example, Montarnal et al. reported a concept for healing cross-linked polymer network by dynamic bond exchange reactions [133]. A cross-linked sample broken into pieces was reheated over $180^{\circ} \mathrm{C}$ and reprocessed in an injection molding machine. It was found that the initial geometry and properties have been recovered due to the healed polymer chains at a high temperature. Transesterification reaction occurs between two $\beta$-hydroxyl-esters, leading to rearrangement of network topology while preserving the total number of links and integrity of the network functionality.

[Insert Table 2 here] 
In contrast to the dynamic bond exchange, reversible Diels-Alder (rDA) and hetero DielsAlder (HAD) reactions could make the cross-linked polymer network a temperature-sensitive polymerization-depolymerization equilibrium [136-138]. For example, Zhang et al. reported a thermally healing-on-demand thermoset polymer in order to resolve the issue on recycling of thermosetting materials at the end of life cycle [68]. The thermoset polymer was prepared by the Paal-Knorr reaction of the PK with furfurylamine, where the PK was used as precursor for DA reactions. When the fractured sample was heated over $110^{\circ} \mathrm{C}$, which was above its glasstransition temperature, the thermoset polymer became soft because of the opening of the DA adduct, then reactions occurred between the PK-furan and bis-maleimide, leading to regeneration of the DA adduct. Upon cooling, the sample recovered its original shape, which was repeatable without any loss in mechanical properties. The uniqueness in this healing-on-demand behavior persists in its ultrafast healing response, such as 5 minutes upon heating (among $110-150^{\circ} \mathrm{C}$ ) during the healing event.

Repeatable crack healing through photostimuli and simultaneously macroscopic fusion of separate pieces can be achieved by photo-reversible reshuffling reaction [79, 82, 83, 135]. For example, Ling et al. reported a mendomer synthesized by cross-linked polyurethane containing dihydroxyl coumarin derivative 5,7-bis(2-hydroxyethoxy)-4-methylcoumarin (DHEOMC). Upon photo stimulation, the fracture surfaces were successfully healed within two hours. The dynamically reversible C-ON bond and S-S bond shows an interesting behavior of frequent cleaving but immediate rebonding when under certain hemolysis temperatures [71]. Upon the thermal treatment at $130^{\circ} \mathrm{C}$, covalent $\mathrm{C}-\mathrm{ON}$ bonds fission and radical recombination synchronously took place among alkoxyamine moieties. Eventually, the fracture surfaces could be completely healed after 2.5 hours. It was pointed out that the alkoxyamine could be used for 
healing structural applications on-demand based on dynamically reversible C-ON bonds no matter they appear in linear or cross-linked polymers.

\subsubsection{Noncovalent Bond Interaction}

As classified in Fig. 3, the noncovalent bond interaction includes reversible non-covalent bonds (ionic bond [100, 101], and metallic bond [66, 74, 77]), and intermolecular force (e.g., hydrogen bond [139, 140], and Van der Waal's bond [141]). In terms of pure ionomer of EMAA or in the form of ionomer blends of EMAA and functionalized elastomers ENR and PISP, the healing of puncture-induced damage is due to the ionic bond interactions in their molecular structure. Below the order-disorder transition $\left(\mathrm{T}_{\mathrm{i}}\right)$ temperature, ionomers are solid. While upon temperature change, the structure of ionomer rearranges itself over time due to the ionic interactions or aggregations. Metallic bond in polymer is designed for the crack healing applications in electric field, magnetic field, or optical field. One example is that, due to the endowed conductive properties, the structure status of the polymer can be monitored real-time through its electrical feedback. The structure status includes microcrack initiation, stress history, and so on. The unique features can be lost if used improperly, like internal damage. An organometallic polymer was developed by compounding between N-heterocyclic carbenes (NHCs) and transition metals at molecular level [66]. As shown in Fig. 5a, the chemical dynamic equilibrium between molecules, like a monomer species (1) and an organometallic polymer (2), is controlled by an external stimulus. The synthesis of such a polymer was a challenge as pointed out in their work because of the requirement for the synthesis of appropriately functionalized multitopic NHCs poised for polymerization. Owing to the transition metals and structurally dynamic equilibrium, the synthetic organometallic polymer was an electrical conductive and crack-healing material. The healing-on-demand mechanism is elucidated in Fig. 5b. The created microcrack results in inherent electrical resistance change (i.e., high-resistance/low-current). As 
a result, the voltage bias generates localized heat at the microcrack site. In turn, local heat overcomes the fracture surface kinetic barriers, leading to reformation of the broken NHCs-metal bonds. Consequently, the system is electrically driven back to its original state (i.e., lowresistance/high-current) and the microcrack is healed.

\section{[Insert Figure 5 here]}

A group of polymers perform their crack healing via intermolecular force, such as hostguest interaction [85, 142], dynamic polar group [70], weak hydrogen bond of $\pi-\pi$ stacking [141], hydrogen bond through dynamic olefin metathesis [122], and hydrogen bond interaction between terminal-carboxyl groups [63], UPy groups [90, 139], PA-amide groups [109, 111], supramolecular clusters [112], and hydroxyl groups [140]. The on-demand conditions for driving crack healing can be $\mathrm{pH}$ aqueous solution, water, heat treatment, UV light, electrical field, and magnetic field. For example, the acryloyl-6-aminocaproic acid hydrogel exhibited repeatable damage healing ability at low $\mathrm{pH}$, at which the terminal-carboxyl groups were protonated to generate hydrogen bonds with other terminal-carboxyl groups or amide groups across the interface [63]. Fig. 6 shows the performance of hydrogel healing via change in $\mathrm{pH}$. The weld of the fracture surface took only two seconds, but it took 24 hours for complete crack healing. Another pH-responsive repeatable healing-on-demand hydrogel was investigated by Krogsgaard et al., by incorporating additional features of mussel adhesive proteins [64]. The 3,4dihydroxyphenylalanine was attached to amine-functionalized polymeric hydrogel. The healing was a result of the formation of networks through the reaction with ion at $\mathrm{pH}$ of 8.0. The healing event was completed within $45 \mathrm{~min}$.

[Insert Figure 6 here] 


\section{$3 \quad$ Healing of Polymer Composites}

The repair of damage-induced crack in polymer composites has been well discussed including both intrinsic and extrinsic strategies $[6,8,12,14,15,20,47,127,128,143,144]$. Like in Section 2, here we focus on several specificities such as composite type, damage type, crack approaching method, healing mechanism, healing measurement, healing efficiency, repeatability, healing condition and time, as summarized in Table 3 . The healing-on-demand polymer composites can be categorized into five types, which will be discussed in the following subsections.

\subsection{Capsulated Polymer Composites}

These polymer composites incorporate capsules of various sizes uniformly distributed within the matrix materials. Based on the size, capsules can be categorized into micro size [145$150]$ and nano size $[57,151,152]$. They are filled with liquid healant or liquid crosslinking hardeners (e.g., catalyst). Healant can be a crack healing agent, which is used for mechanical property restoration; or can be a function restoration agent for conductivity restoration [153-155], anticorrosion [156], and water resistance [157]. Upon fatigue loading or incidental loading, the capsules are ruptured by propagating micro-cracks in the matrix. The loaded healant is released from the capsules, filling in the propagated micro-cracks via capillary action, and comes into contact with crosslinking hardeners; or released liquid crosslinking hardener comes into contact with embedded healant to initiate polymerization at the micro-crack site, leading to healing-ondemand healing, in autonomous manner. As shown in Fig. 7, crack healing by capsules includes both single capsulated polymer composites and dual-capsulated polymer composites. In Fig. 7(a), the "question mark" indicates that the capsule can be filled with either liquid healant [158-165] or crosslinking agent [166, 167], depending on the design of the material system. Fig. 7(b) indicates that two types of capsules are embedded in the polymer matrix, which are encapsulated 
with healing agent and crosslinking hardener individually $[168,169]$, or healing agent and liquid initiator individually [170].

[Insert Table 3 here]

[Insert Figure 7 here]

Since a microcapsule crack healing system with the ability to heal cracks for mechanical property restoration was reported on structural polymer composites [171], microencapsulation has motivated studies from multiple academic disciplines to a wide variety of industrial applications. Healant was encapsulated in a microcapsule and the catalyst was well dispersed within the composite matrix in the first reported single-microcapsule polymer composite. The catalyst deactivation, as well as the potential side reactions between catalyst and polymer matrix after embedding the catalysts in the matrix, was a major challenge facing this type of healing-ondemand composites. Faced with these challenges, two solutions have been proposed: (1) no catalyst and (2) catalyst protection.

Yang et al. reported a catalyst-free crack healing polymer composites by incorporating IPDI-loaded microcapsules [159]. The crack healing behavior was triggered by humid or wet environment, in which the ruptured healant IPDI was polymerized. Photo-induced healing through the use of ruptured healant methacryloxypropyl-terminated PDMS was reported by Song's group, who prepared a polymer composite with crack healing ability within 4 hours upon exposure to sunlight [190]. The advantage of this system persists in its repeatability in damage healing due to the reversible polymerization between the healant and host matrix.

The agent for catalyst protection could be wax if solid catalyst is used [176-178, 183, 245], and polyester shell or glass shell if liquid catalyst is used [191, 192, 195]. Since both healant and catalyst are capsulized, it is called dual-microcapsule polymer composite. Obvious 
advantages of this system are: (1) better thermal tolerance; (2) better corrosion resistance if shelled by glass; (3) fast polymerization speed (i.e., fast crack healing rate) due to two liquid phases.

\subsection{Hollow-fiber Reinforced Polymer Composites}

Crack healing in hollow-fiber reinforced polymer composites was investigated through (1) one-part liquid healing agent, (2) two-part liquid healing agent and liquid hardener, and (3) twopart liquid healing agent and encapsulated catalyst [208].

The hollow glass fiber (HGF) used in this system is an ideal medium for storing healing agents due to its good mechanical properties as structural reinforcement, which provides impact protection to some extent. Microcrack damage within structural polymer composites leads to fracture of the hollow glass fiber, which releases liquid agents to fill in the microcracks by capillary action and heal them through healing agent polymerization. Compared to the HGF preparation technique, the preparation of hollow polymer fiber (HPF) is much more effective. The healing agents or catalyst-solvent were filled into polymer fibers during the processing of hollow polymer fiber, forming a core-shell bead-on-string morphology. The advantage of this technique is the capability in controlling the diameter of HPF from micro- to nanometer scales [246]. In contrast to the functionalized capsule-based coatings, the HPF-based healing-ondemand coatings could solve a number of issues with chemical incompatibilities between various matrices and healing agents associated with the dispersing capsules in the matrix precursors.

\subsection{Vascular Networks based Healing-on-Demand Polymer Composites}

The microcapsule and hollow fiber serve the function of liquid storage and delivery. By implementing vascular networks, the healant from a reservoir is delivered to a damage site via a network of vessels. The advantage of vascular based healing-on-demand polymer composites is 
that it provides the healing ability for large damage volume and multiple healing events as well as the replenishment of the healant. The branching macrovascular network was inspired by human circulatory system [226] and plant vasculature system [247, 248], as shown in Fig. 8. This branching network is to avoid the loss of healing repeatability due to bleeding clots. Additionally, 3D vascular system gives higher potential for fast healing response [230].

\section{[Insert Figure 8 here]}

The healant or crosslinking hardener was protected by a shell from directly contacting the host matrix in the microcapsule system as well as the hollow fiber system. However, in the vascular network system, the healant or crosslinking hardener was in direct contact with the matrix while in delivery. This is one of the concerns when implementing vascular network for crack healing purposes. In the case of large volume damage, it requires overcoming the interplay between mass transport, environmental factors, intrinsic forces (such as surface tension), and extrinsic forces (such as gravity) that act on the liquid reagents [222, 223]. How to heal largescale or wide-opened crack without mass loss is a challenge. To date, there are two approaches to deal with the challenge. One is the close-then-heal (CTH) method proposed by Li's group (to be discussed in the next section), and the other is the method proposed by White's group [222]. By using a vascular system of microchannels, White et al. proposed two stages: (1) gel-stage (liquid to gel) to plug the hole quickly and prevent bleed-out of the healing agent; (2) polymerizationstage (gel to polymer) to undergo polymerization of the healing agent and heal the large volume crack. By evaluating the impact damage on the healed sample, about $62 \%$ of the impact energy (on a time scale of $3 \mathrm{~h}$ room temperature curing) was recovered. The challenge is that the surface tension would become insufficient to retain the unreacted fluid when the damage size exceeds a certain threshold, leading to bleeding-out of healant. 


\subsection{Heling in Layer-by-Layer Coating/Film}

A skin material with flexibility, healing-on-demand and damage sensing was studied and fabricated by using a layer-by-layer technique with copperclad imidized polyimide sheets and Loctite Impruv $365 \mathrm{UV}$-curable epoxy, which was used as structural adhesive as well as crackhealing fill material [232]. After an intentional puncture, the damaged skin can heal itself through the flow of UV-curable epoxy under UV exposure in a matter of minutes. This fast healing behavior is one of the advantages exhibited by healing-on-demand skin.

Andreeva et al. designed a healing-on-demand anticorrosion coating system on aluminum alloy based on $\mathrm{pH}$-sensitive polyelectrolyte/inhibitor sandwich-like nanostructures [249]. The PEI, PSS and 8-hydroxyquinoline nanolayers were deposited on the pretreated aluminum alloy under the layer-by-layer deposition procedures. The nanometer-thick novel coating protected the aluminum alloy effectively from corrosion. The healing behavior of the coating prevented the propagation of corrosion on metal surfaces based on the suppression of accompanying physicchemical reactions. The mechanisms for healing-on-demand of the corrosion damaged areas included $\mathrm{pH}$ neutralization, passivation by inhibitor, and healing by mobile polymer layers. Once the corrosion occurred, the inhibitor was released to the damage site on the substrate surface to prevent adsorption of chloride ions. Due to the changes of local $\mathrm{pH}$, the polyelectrolyte complex was swollen and polymer chains diffused through the rupture surfaces. The gradual evolution of ionic bonds results in damage healing from the healing-on-demand coating system.

Water-induced healing synthetic materials are used for applications from food packaging to sub-water coating $[250,251]$. A healing-on-demand polyvinyl based coating blend was reported by Ensslin et al., who used the blends of PVAc and PVA-PEG in the field of pellet coating [252]. The PVAc/PVA-PEG coating in the damage site started to swell under the exposure to water, leading to the closing of holes, craters, and clefts, which prevent a burst release. However, the crack-healing efficiency needs further investigation. 


\subsection{Solid-state Healant Embedded in Polymer Composites}

The intrinsic self-healing polymers described in Section 2 could be fabricated into small pellets and dispersed into a polymer composite matrix as a healant. In this system the crack is healed once the embedded healable particles are in contact, through molecular interdiffusion [253], dynamic covalent bonding [254-256], non-covalent bonding [239], intermolecular force $[257,258]$, and so on. However, crack approaching is a prerequisite and is a challenge when the crack opening is wide.

\section{Close-Then-Heal Strategy for Polymer Composites}

From the above reviews, it is seen that some healing schemes need external help, i.e., bringing fracture surfaces into contact manually before healing occurs. While this is legitimate in lab scale specimens, it represents one of the greatest challenges in real world structures. This is because in large scale structures, fractured structural elements cannot be brought in contact manually. If they are forced together, new damages may form [47].

It is a straightforward idea to utilize the shape memory effect for crack closure because cracks can be treated as a type of pseudo plastic deformation, and the shape memory effect can restore the original shape upon external stimuli. However, the ability to close cracks depends on (1) the level of programming and (2) the constraint during shape recovery [47]. For some shape memory effect based applications such as coatings, the system uses scratching, indentation, or cracking itself as programming. Clearly, if there is no significant barrier to resist the shape recovery, such as a free-standing specimen or panel, the crack can be closed if the shape recovery ratio is close to $100 \%$. However, if there is a significant barrier to resist free shape recovery, such as a specimen or panel with fixed boundary or under external tensile load, the crack cannot be closed. Therefore, energy storage by programming is usually required and is a 
better way for crack closure as it can be designed to consider the level of barrier to resist shape recovery and the shape recovery ratio [47].

In their review paper, $\mathrm{Hu}$ et al. clearly defined two types of crack healing schemes based on shape memory effect [259]. One is free shape recovery and the other is constrained shape recovery. Most recently, Yougoubare and Pang compared the two popular shape memory effect based crack closure schemes [260]. One is shape memory assisted self-healing (SMASH) proposed by Rodriguez et al. [261] and Luo and Mather [262], and the other is close-then-heal (CTH, firstly close the crack through confined expansion of the SMP matrix, and then heal it by embedded thermoplastic particles), which was proposed by Li et al. [242, 244] based on their previous test results of healable SMP syntactic foam [263]. According to Yougoubare and Pang, the fundamental difference between SMASH and CTH is that SMASH targets non-load carrying materials, uses no constraint during shape recovery, does not conduct programming, and is usually suitable for microcracks and small indentations; on the other hand, CTH focuses on load carrying material, considers constrained shape recovery, needs programming depending on the width of crack to be closed, and is suitable for wide-opened crack and large indentation. It must be emphasized that shape memory effect does not necessarily heal the material. It only narrows or closes the crack. In order to heal the crack, it must be combined with other physical or chemical healing schemes such as shape memory polymer with self-healing capability or a combination of shape memory polymer with external healing agent [47]. In the following, we will review the shape memory effect based self-healing schemes, particularly SMASH and CTH. After the discussion on the topics of SMASH and CTH, the crack healing mechanisms, within the healing-on-demand polymer materials framework, will be covered via healing theories. 


\subsection{Shape Memory Assisted Crack Healing}

Over the past decade, shape memory materials have been used to improve the healing-ondemand process by providing functionality to partially or fully close cracks. A poly $(\varepsilon-$ caprolactone) (PCL) based composite system is one of the examples used to explain this approach [261]. The advantages of shape memory polymer materials are the ability to sustain high strain (up to 500-800\%), low response temperature, tunable elastic modulus, and low density [264]. Rodriguez et al. reported SMASH of polyurethane blends with varying compositions. The blends were synthesized via the incorporation of a covalently cross-linked network by end-linking end-functionalized n-PCL as a thermoset for shape-memory and a linear 1-PCL thermoplastic for healing. Upon the on-demand thermal treatment at $80^{\circ} \mathrm{C}$, the fractured surfaces were driven back for contact by the n-PCL shape-memory ability; and then, surface wetting and chain diffusion by 1-PCL occurred at the crack surface. The equilibrium and randomization of PCL networks were achieved over time and thus the fracture surface was healed, as shown in Fig. 9. This damage-healing application overcomes the above mentioned limitation, i.e., crack closure without manually pushing the fractured parts together.

\section{[Insert Figure 9 here]}

Luo and Mather proposed a new SMASH strategy tailored for coating/corrosioninhibition applications [262]. Nonwoven nano- and micro-PCL fibers were distributed in a shape memory thermoset matrix by an electrospinning process. Both fibers and matrix served as coating agents on a steel substrate. The randomly oriented and evenly distributed PCL fibers can heal larger cracks and defects due to the more significant flow of the liquefied PCL fibers compared to the previous SMASH example. The working principals during the healing-ondemand process include two steps, which take place simultaneously: (1) crack closure due to the shape memory behavior of the SMP matrix, which releases stored strain energy in the plastic 
zone after thermal treatment, and (2) crack rebinding (i.e., healing) due to the melting and flow of the PCL fibers. It was reported that the crack-healing performance could be conducted by heating at $80^{\circ} \mathrm{C}$ for $10 \mathrm{~min}$, leading to almost completely restored corrosion resistance.

\subsection{Close-then-Heal}

It is emphasized here that, the CTH strategy is different from SMASH. The healing-ondemand composite by CTH approach, as proposed, undergoes a process of crack closure by constrained shape recovery, followed by crack healing through healing agents. As compared to SMASH, the boundary condition of the specimens or structural components per the CTH scheme does not need to be free, and the shape recovery ratio does not need to be $100 \%$. Therefore, the CTH scheme is appropriate for real world load-bearing structures because these structures are generally constrained at the boundary and/or under external loading during the healing process, and the shape memory capacity of SMPs degrades with time.

It is worth mentioning that $\mathrm{CTH}$ is in line with the widely accepted five-step healing theory proposed by Wool and O’Connor [59]. The first two-steps, (i) surface rearrangement, (ii) surface approach, correspond to "Close" in CTH, and the last three steps, (iii) wetting, (iv) diffusion, and (v) randomization, correspond to "heal" in CTH.

A concern with CTH may be that one needs to design or manually provide the external confinement. Actually, the external confinement or constraint needed in CTH is provided naturally by the materials and structures. According to $\mathrm{CTH}$, only local or in-situ heating surrounding the crack in a specimen or panel is needed to close the crack and heal it. The rest of the specimen or panel is still "cold", which provides the external constraint. Furthermore, constraint can be provided by the architectural configuration of composite structures, such as sandwich face sheets [263], 3-D woven fabric [265], grid skeleton [266], etc. 
Another concern with crack closure by shape recovery is that the SMP could be very soft at high temperatures. In several experimental studies, the healing temperature is always slightly above the glass transition temperature, but sometimes even within the glass transition temperature zone $[263,265,266]$, as long as one can find a healing agent which melts and bonds at that healing temperature. When the healing temperature is slightly higher than the glass transition temperature but still within the glass transition zone or slightly above the zone, the SMP is still stiff enough. Also, as indicated in several of previous studies, one only needs to heat up locally surrounding the crack according to CTH. The rest of the structure is still "cold". Therefore, the overall structure is still very stiff [47, 267]. Furthermore, research has proved that time-temperature equivalent principle holds for shape recovery, which suggests that, as long as the healing temperature is within the glass transition zone, the shape recovery can occur even at a temperature slightly below the glass transition temperature [268]. What needed is a longer healing time. Again, as long as one can find a suitable healing agent, $\mathrm{CTH}$ can proceed when the SMP is still considerably stiff.

Currently, the CTH scheme has evolved into three sub-systems, i.e., SMP as a matrix, SMP as a dispersed reinforcing phase, and polymer artificial muscle as an inherent actuator. In other words, the crack closing can be driven either by a compression programmed shape memory polymer matrix or tension programmed shape memory fibers or artificial muscles. The following three subsections will discuss in detail how the CTH scheme works in these three sub-systems.

\subsubsection{Shape Memory Polymer as Matrix}

Shape memory polymers are trained by a programming process, which is necessary to create a nonequilibrium configuration and enables them to have shape recovery capability [268276]. The driving force for shape recovery is the conformational entropy of the molecular segments in terms of micro-Brownian thermal motion. Upon heating to the polymer glass 
transition temperature $\left(T_{g}\right)$ for cross-linked polymer network or melting temperature $\left(T_{m}\right)$ for semi-crystalline polymer, the molecular mobility increases and the orientation of molecular chains tend to be random, accompanied by an increase in the conformational entropy. The increase in entropy creates the driving force for shape recovery. It is an autonomous process for molecules to recover from nonequilibrium to equilibrium states.

Li and John developed a new shape memory polymer based syntactic foam and foam cored sandwich composite for the purpose of repeatedly healing impact damage [263]. The syntactic foam was prepared by dispersing $40 \%$ by volume of glass microballoons into a shape memory polystyrene matrix. The foam cored composite sandwich plates were fabricated by vacuum assisted resin infusion molding (VARIM) technology. In order to have shape memory effect, the composite was programmed by a typical three-step programming process. In step 1, pre-deformation was initiated in a rubbery state at a temperature above the glass transition temperature of the shape memory polymer. In step 2 , strain storage process was conducted by maintaining the pre-deformation constant while cooling down to below $\mathrm{T}_{\mathrm{g}}$. In step 3 , the load was removed at the temperature lower than $\mathrm{T}_{\mathrm{g}}$. This completes the typical "hot" programming process (at a temperature above the glass transition temperature). It is noted that programming does not necessarily need a temperature event. Cold programming at a temperature below the glass transition zone also works as long as the prestrain level is beyond the yielding point of the shape memory polymer $[268,270]$. It is noted that, the compression programming process was integrated with the fabrication process of the sandwich panel per the VARIM technology in Li and John's study. After impact damage, the damage-healing of the shape memory polymer based composite was due to constrained shape recovery of the compression programmed foam core. The partial confinement to the damaged foam core was provided by materials surrounding the crack in the in-plane direction and by the skin in the transverse direction during the shape 
recovery process. In this study, because the composite was programmed by transverse compression, it tended to have a volume growth during shape recovery. Because of the constraint, such a tendency was not allowed. As a result, the foam was pushed into any internal open space, leading to crack narrowing or closing. This fast response healing-on-demand shape memory polymer based composite could take up to seven damage and healing cycles. In order to provide better constraints during shape recovery process, a new architectural design was proposed, which led to inherent constraint to resist volume growth in the shape memory polymer matrix. The developed new composite architecture design included 3D woven fabric reinforced shape memory polymer composite [265] and grid stiffened composite sandwich structure [266]. The 3D woven fabric or the fiber reinforced grid skeleton provides strong constraint to the SMP foam core, in addition to its reinforcement effect.

While the previous studies by Li et al. have utilized constrained shape recovery for closing impact induced cracks, the molecular length scale healing was not conducted. Li and Nettles firstly proposed a two-step healing scheme of close-then-heal (CTH), similar to the biological healing of wounds in the human skin, for molecularly and repeatedly healing structural length scale cracks [242]. This scheme was further elaborated by Li and Uppu [244]. Fig. 10 shows the schematic of the $\mathrm{CTH}$ scheme of the proposed syntactic foam. The SMP based structure obtains its permanent shape first. Afterwards, the structure is programmed at a temperature above $\mathrm{T}_{\mathrm{gs}}$ but bellow $\mathrm{T}_{\mathrm{gp}}$ by compression to reduce structure volume. A temporary shape of the structure is achieved for working after cooling down below $\mathrm{T}_{\mathrm{gs}}$. If some internal damage such as matrix cracking is formed by service loading during lifetime, the material can be heated above $T_{g s}$ and the material tends to expand in volume (shape memory effect). Due to the external confinement, however, the expansion of the structure is resisted; as a result, the SMP matrix is pushed towards any internal open space, leading to narrowing or closure of the cracks. 
The incorporated thermoplastic particles are then heated to melt and the molten thermoplastic flows into the narrowed crack space by capillary force. The thermoplastic molecules then diffuse into the fractured SMP matrix and establish physical entanglement with the SMP molecules, which are driven by concentration gradient and shape recovery pressure at a temperature above $\mathrm{T}_{\mathrm{gp}}$. After cooling below $\mathrm{T}_{\mathrm{gs}}$, a solid thermoplastic wedge is formed, which glues the fracture surfaces together and prolongs service lifetime. Li and Uppu indicated that each constrained shape recovery (crack closing) represents a new round of compression programming. Also, the thermoplastic healing agent can be melted and solidified quite a few times. Therefore, the healing is repeatable and only one time programming is needed before service. Another feature of this system is that it depends on physical change only. No chemical reaction is involved in the system, which ensures repeatability. It is noted that, while CTH is conceptually divided into two steps, it is actually one step in practice, i.e., heating up all the way to the bonding temperature of the thermoplastic healing agent.

\section{[Insert Figure 10 here]}

In order to validate the $\mathrm{CTH}$ scheme, a particulate composite with shape memory polystyrene matrix dispersed by copolyester healing agent was prepared and tested. By studying the copolyester-polystyrene shape memory polymer composite and the SMP based syntactic foam, it is shown that the close-then-heal scheme works, which leads to healing of structurallength scale damage repeatedly, efficiently, molecularly, and timely [243, 244, 265]. As pointed out by Li et al., the combination of thermoplastic particles and close-then-healing healing process was able to heal wide-opened cracks with a small amount of healing agent (as low as $3 \%$ by volume) [244]. The "do-it-yourself" manner [277] in crack closing and healing in polymer matrix has been applied to various applications including syntactic foam [278-281], sealant [282284], fiber reinforced polymer composites [285], and healable composite joint [286]. 


\subsubsection{Shape Memory Fibers as Dispersed "Suture"}

While healing of cracks in SMP matrix has been successful, the challenge is how to heal cracks in conventional thermosetting polymers which do not have shape memory capability. One way to do this is to add shape memory fibers to the matrix, similar to embedded sutures when doctors stitch wounds in human skin. For shape memory fibers based polymer composites, the self-healing mechanism is similar to the two-step close-then-heal (CTH) scheme. The created matrix crack is narrowed or closed by embedded pre-tension programmed shape memory fibers first through constrained shrinkage, followed by crack healing by healing agents, like liquid healing agent/hardener or molten thermoplastic [47]. From recent publications, the shape memory fibers embedded in polymer composites include shape memory alloy (SMA) wires and shape memory polymer (SMP) fibers. This approach, utilizing shape memory alloy wires or shape memory polymer fibers to pull cracked surfaces closer by thermal-activated shape recovery forces, was mainly studied by White's group, Huang's group, and Li's group.

The difference between shape memory polymer material based and shape memory alloy material based polymer composites is the level of cracks that can be closed. SMA wires are featured as having large recovery force but small recovery strain, which is opposite to SMP fibers.

SMA has the capability to memorize its original shape after a large pseudoplastic deformation when subjected to external force [287-291]. It tends to contract if it is heated above the austenite transformation temperature. Such shape recovery behavior of SMA has been applied to intrigue crack narrowing in the self-healing applications [292-297]. Kirkby et al. investigated the influence of SMA wires on the self-healing properties by combining SMA wires with a self-healing polymer [292, 293]. In their study, the microcapsulated liquid healing agent and wax-protected Grubb's catalyst microspheres were mixed and embedded in the polymer 
matrix. The SMA wires were embedded in the polymer composite as well. After a crack was opened in a tapered double cantilever beam specimen, the SMA wires exhibited shape memory functionality, leading to the crack closure by passing a current through the wire. The $0.5 \mathrm{~A}$ current provided to each SMA wire generated heat and increased the temperature to above $80^{\circ} \mathrm{C}$, which in turn improved the degree of polymerization of the healing agent during the healing process. The healing-on-demand composite showed that significant improvements have been achieved in the polymer composite by incorporating SMA wires that bridge over the opened cracks. Furthermore, SMA spring was embedded in a cylindrical silicone melting glue (SMG) sample to pull fracture surfaces into contact [275]. As compared with SMA wires, the advantage of SMA spring is the efficient stress transfer from shape recovery and larger recovery strain, under thermal stimulus. Hence, it generates high compressive force during the crack closing process, leading to fast and efficient crack healing, which is about $5 \mathrm{~min}$ to heal a cylindrical sample with a diameter of $7.56 \mathrm{~mm}$. Li indicated that the efficiency for a shape memory fiber to narrow or close cracks depends not only on recovery force, but also on recovery strain, or on recovery energy density [47]. He further indicated that, due to the very limited recovery strain of SMA wires, SMP fibers may be more appropriate for closing cracks with wider opening. He also indicated that, in order to overcome the constraint during crack narrowing process, increasing the recovery stress of SMP fibers is needed to further enhance the crack closing efficiency of SMP fibers because SMP fibers have already had considerable recovery strain.

The healing-on-demand polymer composite by SMP fibers was firstly reported by Li and Shojaei [298], who incorporated pre-stretched shape memory polyurethane (SMPU) fibers in polymer composite as a grid skeleton (ribs and z-pins). Macroscopic crack was introduced in a local site on the composite. When local heating was applied, the crack was closed or narrowed as a result of the constrained recovery of the SMPU fiber ribs and z-pins (constrained shrinkage). 
Following closure of the crack, the dispersed thermoplastic particles were melted and flowed into the narrowed or closed crack by capillary force, and diffused into the fractured surface by concentration gradient and shape recover pressure. By cooling down to below the glass transition temperature of the SMP fibers, the solid wedge was formed, leading to crack healing. Fig. 11 shows the two-step self-healing behavior by continuous SMPU fibers, i.e., close-then-heal mechanism. Li et al. investigated the healing-on-demand application further in polymer composite by pre-tensioned continuous SMPU fibers [267, 299]. It was shown that the colddrawing programming process was necessary for healing efficiency enhancement. It is noted that they used fixed boundary condition in the on-demand healing test, i.e., free shape recovery of the beam specimens was not allowed. This suggests that the SMP fiber based CTH scheme can be used in real world structures or structure components, which are usually constrained at the boundary.

\section{[Insert Figure 11 here]}

Unlike SMA wires, SMP fibers have low recovery force. In order to increase its recovery force, SMP fibers need to be heavily programmed. The reported technique for SMP fiber programming is the cold-drawing programming, i.e., pre-tensioning at a temperature below the glass transition zone. The programmed SMP fibers exhibit higher stress recovery than the nonprogrammed ones [300]. The stress recovery is necessary for crack closure; otherwise the shape recovery would not be able to overcome the barriers and to bring the fracture surfaces together into contact. The greatest challenge in the use of SMP fibers is its structural relaxation after colddrawing programming, which potentially hinders the utilization of shape memory polyurethane fibers for healing-on-demand applications. Zhang and Li studied the structural relaxation behavior of tension programmed SMPU fibers based on molecular-level force model, reptation model, and thermodynamics theory [301]. They pointed out that the programmed SMPU fibers 
can recover enough force for crack closing even after a time scale of 13 years of structure relaxation, which provides a theoretical background that the programmed SMPU fibers, after years of hibernation, still possesses the crack closing ability when triggered by thermal stimulus.

Li and Zhang extended the investigation on the healing-on-demand polymer composite from the programmed continuous SMPU fiber to programmed short SMPU fiber [302]. Continuous SMPU fibers were programmed firstly and then cut into short fibers. Short SMPU fibers and thermoplastic particles were embedded into a conventional thermoset polymer matrix. After three-point bending damage of notched beam specimens, the specimens were heated to $80^{\circ} \mathrm{C}$, following the $\mathrm{CTH}$ scheme, and resulting in crack healing. It again proved that this subsystem can heal millimeter-wide cracks repeatedly, efficiently, and timely.

\subsubsection{Polymer Artificial Muscle as Inherent Actuator}

In all animals and humans, muscle is a soft tissue that constitutes of a part of the musculoskeletal system. It is the only component of the system that enables our body to move through contracting and even fast contracting at higher speed upon stimuli. Analogous to natural muscle, polymer artificial muscle from fishing line could contract fast and deliver large strokes from inexpensive high strength polymer fibers, such as commercial fishing lines [303, 304, 305]. Since repeatable contraction is based on anisotropic thermal expansion in fishing line axial and radial direction, it contracts even after many actuation events without considering its structural relaxation and chemical stability [306]. Structure relaxation has been a challenge topic for shape memory materials when used for crack healing applications at a long-term time scale. Therefore, it is worth studying polymeric artificial muscles when using the $\mathrm{CTH}$ scheme in healing damage induced cracks. Zhang and Li have reported embedding a uniaxial polymer artificial muscle into a thermoset polymer composite beam to close wide-opened cracks [307]. Three-point bending damage to the notched beam specimens can be healed even at a constrained boundary condition 
upon local heating, undergoing the close-then-heal procedure. The fractured beams were heated locally for $10 \mathrm{~min}$. The healing efficiency was investigated at both free boundary condition and fixed boundary condition, by measuring fracture peak load. The fast contraction of artificial muscle brings the fractured surfaces in spatial proximity; following crack closure, the molten healing agent fills in the crack via capillary action and bonds the two fracture surfaces by diffusion and randomization. Fig. 12(a) shows an illustration of natural muscle contraction. Physically, the contraction of muscle generates tension on both connections. Fig. 12(b) schematically presents the crack closing or narrowing due to on-demand artificial muscle contraction and healing of the healing-on-demand polymer composite. With $60 \%$ prestrain of the reinforcing polymer artificial muscle, over $60 \%$ of healing efficiency was achieved at free boundary condition and $54 \%$ at fixed boundary condition after repeated damage-healing cycles. Fig. 12(c) shows the crack closing and healing performance.

[Insert Figure 12 here]

\subsection{Healing Theories and Healing Efficiency Evaluation}

\subsubsection{Healing Theory within the Continuum Damage Mechanics Framework}

In the continuum damage mechanics framework, damage is represented by a damage variable. Healing can be treated as the opposite process of damage. Therefore, healing variables can be defined the same way as damage variables. Polymer damage usually involves finite deformation and thus it is highly nonlinear, and both viscoelasticity and viscoplasticity need to be considered. In damage-healing studies, damage inside the material at the micro-scale level could be represented by measuring changes in elastic modulus via damage variables [308-310]. Voyiadjis et al. [311-313], Shojaei and Li [314], and Shojaei et al. [315] used this idea to model the viscoplastic-viscodamage-viscohealing behavior of shape memory polymer matrix during damage and healing. 
By introducing internal variables, the Helmholtz free energy (HFE) function is obtained and decomposed as follows [311]:

$$
\begin{aligned}
& \psi\left(\varepsilon_{i j}, \varepsilon_{i j}^{p}, \alpha_{i j}, p, d_{i j}, d_{i j}^{K}, d^{I}, h_{i j}, h_{i j}^{K}, h^{I}\right) \\
& =W\left(\varepsilon_{i j}, \varepsilon_{i j}^{p}, d_{i j}, h_{i j}\right)+H\left(\alpha_{i j}, p, d_{i j}^{K}, d^{I}, h_{i j}^{K}, h^{I}\right)+G_{d h}\left(d_{i j}, h_{i j}\right)
\end{aligned}
$$

where HFE is a function of thermodynamic fluxes and is decomposed into elastic part $W\left(\varepsilon_{i j}, \varepsilon_{i j}^{p}, d_{i j}, h_{i j}\right)$, hardening function $H\left(\alpha_{i j}, p, d_{i j}^{K}, d^{I}, h_{i j}^{K}, h^{I}\right)$, and damage-healing function $G_{d h}\left(d_{i j}, h_{i j}\right)$. The damage-healing function took into account the microcrack as well as microsurface propagation and recovery. The idea is that part of the energy in a damaged material is converted to surface energy and the remaining energy is converted to heat. When a healing event occurs, the surface energy reduces due to the polymer chain diffusion process of the healing agent.

By conjugating thermodynamic forces for each flux, the healing criterion for the generalized healing surface is defined as [312]:

$$
\begin{aligned}
& f^{h}\left(y^{h}, y^{h K}, y^{h l}, \sigma, y^{p K}, y^{p I}, y^{d}, y^{d K}, y^{d I}\right) \\
& =f^{h 1}\left(y^{h}-y^{h K}\right)-f^{h 2}\left(y^{h l}\right)-f^{h 3}\left(\sigma, y^{p K}, y^{p I}\right)-f^{h 4}\left(y^{d}, y^{d K}, y^{d I}\right)-w_{0}^{h} \leq 0
\end{aligned}
$$

where $w_{0}^{h}$ is the initial size of the healing surfaces. The first two terms $f^{h 1}$ and $f^{h 2}$ show the respective kinematic and isotropic hardening/softening because of the healing process and $f^{h 3}$ and $f^{h 4}$ represent the effect of the plastic deformation. The derived healing criterion is a function of the relevant healing mechanism. It is argued that the healing of damage is activated when $f^{h}=0$ and $\dot{f}^{h}=0$. 
The overall mapping procedure between the real damaged and fictitious healed effective configurations is shown in Fig. 13. Within the continuum damage mechanics (CDM) framework, the Cauchy stress tensor $\sigma_{i j}$ shows the stress condition in the real damaged configuration, while the effective stress tensor $\bar{\sigma}_{i j}$ represents the stress condition in the effective healed configuration. The vector of $d A n_{i}$ represents the real damaged area, and the vector of $d \bar{A} \bar{n}_{i}$ serves as the effective fictitious area. The effective area, where the loads are carried, increases during the healing process due to healed microscale damages. Hence, it indicates that the effective area grows as the damage heals.

It has been argued to use an indirect measurement method to calibrate damage and healing based on elastic modulus changes during the damage and healing process [308]. The fourth-order anisotropic healed elastic modulus $E_{i j k l}^{h}$ after accomplishing the damage healing process was expressed in term of a new fourth rank healing variable tensor $h_{i j k l}^{\prime}$ [311]:

$$
\begin{aligned}
& E_{i j m n}^{h}=\bar{E}_{i j m n}+\bar{E}_{k l m n}\left(h_{i j k l}^{(1)}-k_{i j k l}^{(1)}-k_{p q k l}^{(1)} h_{i j p q}^{(1)}\right) \\
& E_{i j m n}^{h}=\bar{E}_{i j m n}+\bar{E}_{i j p q}\left(h_{p q m n}^{(2)}-k_{p q m n}^{(2)}-k_{p q k l}^{(2)} h_{k l m n}^{(2)}\right)
\end{aligned}
$$

where $k_{i j k l}$ is a fourth-order anisotropic damage variable tensor. If $h_{i j k l}^{\prime}=0_{i j k l}$, it indicates that no healing at all. In the case that the effective area after healing is equal to the original area, a full recovery event is obtained, and the elastic modulus $h_{i j k l}^{\max }=k_{i j k l}^{\max }$.

[Insert Figure 13 here]

\subsubsection{Chain Diffusion Theory}


As discussed above, solid healing agent such as thermoplastic has been used in healing cracks in polymer composites, including the CTH strategy. During the healing process, physical molecular interdiffusion has been involved. The healing theory is discussed as follows.

Crack healing in polymeric materials follows a five-stage healing theory [59, 315-317], which includes (i) surface rearrangement, (ii) surface approach, (iii) wetting, (iv) diffusion, and (v) randomization. Surface rearrangement and surface approach experience a process by bringing two similar polymeric surfaces into good contact at a temperature above the glass transition. Brownian motion is highly active above this temperature on the interfaces; healing is achieved by the high mobility molecules when a mass of polymer chains move across the interface due to the reduction in thermodynamic barriers (diffusion), and entanglement of molecules (randomization).

The wetting phenomenon in crack healing process was discussed by Wool and O'Connor, concerning the line mode healing for cracks, crazes, and voids [59]. The wetted pools in a domain propagated over the entire domain and interface until they reached an impingement and coalescence of wetted areas. The wetting rate depends on different stages of wetting, which are instant wetting, constant rate wetting, and Gaussian wetting. Among these five stages of healing, the stages of wetting, diffusion and randomization are very important because the healed polymer material mechanical property is determined in these stages by the intrinsic healing function. However, the first two stages, especially stage 2 (surface approach), is also the same important. As indicated by Wool [7], and echoed by Li [47] and Binder [48], bringing the fractured parts in contact represents one of the grand challenges in real world structures. This is also why closing the crack by shape memory effect is necessary, as discussed above.

The behavior of polymer chain diffusion and randomization has been widely studied over the past decades. De Gennes [318] has discussed the molecular chain diffusion and 
randomization by a tube model $[319,320]$, through which the molecular chain was allowed to reptate randomly through one-dimensional back-and-forth Brownian motion, along the randomly coiled conformational tube during a certain time. The diffusion mechanism was discussed by Bousmina et al., who described the diffusion process by Fick's law [321]. Fig. 14 shows the diffusion and randomization behavior in the polymer/polymer interface based on the reptation theory. At $\mathrm{t}=0$, two pieces of polymeric surfaces are brought into contact at a temperature above the glass transition temperature. At the moment $t_{1}>0$, the molecular chain starts to slip out the initial tube and into a new random-shape conformational tube (i.e., $\alpha, \beta, \gamma$ ). At $t_{2}>t_{1}$, the chain reptates completely into the new tube. Due to step reptational relaxations, the tube renewal process will continue until reaching a dynamic equilibrium conformation. In Fig. 14c, the reptation time for chains A and B, located on both sides of the interface with completely reptational diffusion to an equilibrium state, is obtained as follows:

$\tau_{\text {rep }}=\frac{\zeta N^{3} b^{4}}{\pi^{2} e^{2} k_{B} T}$

where $\xi$ is the friction coefficient, $N$ is the number of monomers, $b$ is the effective bond length, $e$ is the segmental chain length, $k_{B}$ is Boltzmann's constant, and $T$ is the absolute temperature. Obviously, the diffusion time before reaching the equilibrium state depends on the polymeric material properties and temperature.

[Insert Figure 14 here]

As discussed above, the interpenetration distance $\chi$ is the average distance of the segments from the interface between $\mathrm{A}$ and $\mathrm{B}$, which is given by [316]:

$\chi \propto\langle l\rangle^{1 / 2}$ 
where $\langle l\rangle$ is the average of chain motion $l(t)$.

Because the wetting and diffusion stages as well as randomization stage determine the mechanical property development, the healed fracture stress is as follows:

$\sigma=\sigma_{0}+\sigma_{d}$

where $\sigma_{0}$ is the stress due to wetting, and $\sigma_{d}$ is the stress due to the reptation of randomly coiled chains at a distance $\chi$ normal to the interface. Assuming that the randomly coiled tubes have Gaussian conformations, the stress $\sigma$ is postulated as:

$\sigma \propto(t / M)^{1 / 4}$

where $M$ is the molecular weight of the polymeric material. It indicates that for a certain polymeric material, the healed fracture stress depends on the diffusion and randomization process.

Shojaei et al. [313] further considered the contribution of shape recovery pressure applied on the narrowed fracture interface to the healing efficiency. They found that the diffusion depth or the healing efficiency increases asymptotically as the healing temperature or shape recovery pressure increases.

\subsubsection{Healing Efficiency Evaluation}

The performance of healing is determined based on a certain criteria. Wool and O'Connor studied the recovery ratio of stress $R(\sigma, t)$ and energy $R(E, t)$ in the case of line mode healing. The general expressions are: 


$$
\begin{aligned}
& R(\sigma, t)=\left[R_{0}+\left(\frac{K}{\sigma_{\infty}} t^{1 / 4} * \dot{\psi}(t)\right)\right] * \dot{\phi}(t) \\
& R(E, t)=\left[R_{0}+\left(K^{\prime} t^{1 / 4}+G t^{1 / 2}\right) * \dot{\psi}(t)\right] * \dot{\phi}(t)
\end{aligned}
$$

where $R_{0}$ is the wetting parameter, $\sigma_{\infty}$ is the fracture strength of the virgin polymeric material, $K$ and $G$ are material parameters, $\dot{\psi}(t)$ is the diffusion rate according to the diffusion initial function $\psi(t)$, and $\dot{\phi}(t)$ is the wetting rate according to the wetting distribution function $\phi(t)$. The theoretical healing efficiency in strength and energy are calculated via Eqs. (9) and (10), which can be compared to experimental data.

The dimensionless recovery ratios $\mathrm{R}$ additionally can be examined and compared based on elongation strain $\mathcal{E}$, tensile modulus $Y$, fatigue life $N$, and general spectroscopy of molecular microstructural parameters via infrared before being healed (i.e., in the virgin state) and after being healed:

$$
\begin{aligned}
& R(\varepsilon)=\varepsilon / \varepsilon_{\infty} \\
& R(Y)=Y / Y_{\infty} \\
& R(N)=N / N_{\infty} \\
& R(I)=I / I_{\infty}
\end{aligned}
$$

where the subscribe $\infty$ denotes the original material property before damage.

Actually, healing efficiency can be determined by many parameters, depending on the property that is to be recovered. These properties, and thus the healing efficiency measurements, can be physical, mechanical, or other functional properties. So far, the majority of healing-on- 
demand studies are focused on recovery of mechanical properties. Therefore, mechanical measurements such as strength, stiffness, ductility, toughness, etc. have been dominating. As discussed by Li [47], even for fracture toughness measurement, the fracture modes need to be clearly defined, such as Mode I, Mode II, and Mixed Mode I \& II, because different fracture modes will yield different healing efficiencies. The dependence of the strength and toughness on the thickness of the healing agent layer has been studied experimentally [126, 322-326].

\section{$5 \quad$ Conclusions and Future Perspectives}

In the past several decades, the desire for lighter, tougher, stronger, and smarter materials in transportation vehicles, energy production, storage, and transport, military equipment and vehicles, infrastructure, chemical processing equipment, offshore oil and gas equipment, and consumer goods, has driven the use of polymers and polymer composite materials. Polymers or polymer composite materials, while have high specific strength, stiffness, corrosion resistance, and design tailorability, are prone to damage due to the various weak interfaces and other inherent properties such as brittleness of thermoset polymers. Therefore, healing-on-demand polymers and polymer composites have been growing at an unprecedented speed, which have emerged as an interdisciplinary class of materials that need collaboration from various science and engineering fields such as mechanical, chemical, biological, electrical, and civil engineering, as well as mechanics, mathematics, physics, and chemistry. Many polymers can heal themselves as long as they are manually brought into contact, which may be the biggest obstacle for real world applications, particularly in load bearing engineering structures, where manually bringing fractured structural components in contact is prohibited.

As observed from Table 1 and Table 3, the development of crack healing in materials undergoes two stages. In the first development stage, almost all attention was paid to how to heal damage on bulk material, film, or coating for solo functionality restoration. Repeatability in 
healing was not concerned. In the second development stage, repeatability as well as multiple functionalities restoration has become a main topic when conducting crack healing. Physical or chemical healing mechanism between fracture surfaces has been well explored by previous researchers. However, fracture surface approaching is always intentionally or unintentionally neglected.

All the healing mechanisms used in healing-on-demand polymers and polymer composites share an essential concept: close-then-heal (CTH). For healing-on-demand polymers the cracks are closed either by their elastic behaviors (such as ionomer) or by manual relocation (most intrinsic healing polymers), followed by crack-healing process through chemical and/or physical interactions across the fracture surfaces under thermal treatment, or chemical treatment, or photo treatment, or electrical treatment, or none treatments under ambient condition. When the CTH scheme is integrated with shape memory polymers, the crack closing step is achieved by constrained shape recovery, which is triggered by heating or by other means depending on the functional groups in the SMP. Such an approach is more realistic for real world structures because a crack in a large engineering structure cannot be closed manually.

SMP matrix based or SMP fiber based or polymeric artificial muscle based system can close and heal wide-opened cracks (up to millimeter scale) per the CTH scheme repeatedly, efficiently, molecularly, and timely. However, minimal human intervention is required to trigger the healing mechanism, such as providing local heating. One of the major advantages of the SMP fiber is that it has good interfacial bonding between the functional fibers and the host matrix. If the fiber is given multi-functionality, like electrical conductivity, it can generate local heat by electricity and thus may lead to fast, repeatable, and more autonomous healing-on-demand effect because the electrical conductivity can be used as a damage sensing device, making the healing more towards an autonomous fashion [47]. Adding damage sensing capability to the CTH system 
opens up new opportunities to make autonomous healing. In addition, the crack closure in $\mathrm{CTH}$ depends on both recovery stress and recovery strain [47]. While SMPs have considerable recovery strain, their recovery stress is comparatively low. Further endeavors should be towards increasing the recovery stress of SMPs and artificial muscles. Both physical means (e.g., cyclic programming) and chemical means (e.g., changing the composition or controlling the sequence of polymerization by mimicking biopolymers, for example, proteins and DNAs) deserve investigation.

Further development in the CTH scheme may also include a combination of shape memory and other intrinsic healing schemes such as shape memory ionomer, shape memory supramolecular, etc. [47], or use intrinsic healable polymers as healing agents. For example, ionomer particles, which have weak shape memory capability, may be compression programmed before embedding into conventional polymer matrix. When triggered by heating, the embedded ionomer particles will expand, which will push the fracture surfaces marching towards each other, and the molten ionomer particles can heal the crack. In other words, ionomer can serve as both a crackling closing device and a healing agent. Still another alternative may be the two-way SMP. This type of SMP expands when cooling down and shrinks when heating up. This unique behavior, which is opposite to the common physical behavior of materials, can be very useful in healing-on-demand applications.

In real world structures, on-demand healing includes structures that are under in-service conditions. Several preliminary explorations have been conducted, such as healing of continuous SMP fiber reinforced polymer beam specimens under fixed boundary conditions [267], polymeric artificial muscle reinforced polymer beam specimens under clamped boundary conditions [307], and short SMP fiber reinforced syntactic foam beam specimens under constant tensile loading [328]. It has been clearly demonstrated that with these in-service conditions 
(fixed boundary conditions, tensile load, etc.), the healing efficiency is reduced. Therefore, in order to validate the performance of real world healing-on-demand structures, it is highly desired that the lab scale specimens be subjected to in-service conditions when conducting healing-ondemand studies.

Healing with external healing agent usually accompanies phase changes. For example, thermoplastic healing agent experiences solid to liquid and liquid to solid phase change, including diffusion and randomization, during the healing process. Currently, continuum damage mechanics $(\mathrm{CDM})$ is used to provide the theoretical healing framework, i.e., healing is treated as a reverse process of damage. However, CDM cannot directly consider the process of the phase change. Also, the current CDM based healing theory is mathematically complex and involves a large number of curve fitting parameters. Therefore, more physics based models are needed. Other theoretical frameworks other than CDM may also deserve investigation. Phase field model, which describes the phase evolution in a physical or chemical process is evolving rapidly in materials science research, and may provide a viable alternative [327].

Healing efficiency is currently evaluated primarily by Mode I fracture test (crack opening). In real world load-bearing structures, various stress conditions exist, which may lead to Mode II (in-plane shear), Mode III (out-of-plane shear or tear), and mixed mode fracture. Therefore, evaluations of healing efficiency in terms of Mode II, Mode III, or mixed fracture modes are also needed.

In summary, although considerable progress has been made in healing-on-demand studies, this area is still in its early stage. Many more issues need to be overcome before they can be used in engineering structures. We believe that this is the time to consider the practical challenges facing self-healing applications, in addition to the fundamental science. The purpose of this review is to throw out a minnow to catch a whale. We believe that with the collaboration 
between materials scientists and engineers, healing-on-demand engineering structures will become a reality in the foreseeable future.

\section{Acknowledgement}

This study was financially supported by National Science Foundation under grant number CMMI 1333997, the Cooperative Agreement NNX11AM17A between NASA and the Louisiana Board of Regents under contract NASA/LEQSF(2011-14)-Phase3-05, and Army Research Office under grant number W911NF-13-1-0145.

\section{References}

[1] Pipes RB, Wetherhold RC, Gillespie JW. Notched strength of composite materials. J Compos Mater 1979;13:148-60.

[2] Gillespie Jr JW, Pipes RB. Compressive strength of composite laminates with interlaminar defects. Compos Struct 1984;2:49-69.

[3] Hinton MJ, Kaddour AS, Soden PD. Failure criteria in fibre reinforced polymer composites: the world-wide failure exercise. Oxford: Elsevier Ltd, 2004. 1259 pp.

[4] Penado FE. Analysis of singular regions in bonded joints. Int J Fract 2000;105:1-25.

[5] Penado FE. Determination of stress intensity factors in cracked bonded composite joints. J Thermoplast Compos 2000;13:174-89.

[6] Urban MW. Self-Healing Polymers. From Principles to Applications. Edited by Wolfgang H. Binder. Angew Chem Int Ed 2014;53:3775-5.

[7] Wool RP. Self-healing materials: a review. Soft Matter 2008;4:400-18.

[8] Wu DY, Meure S, Solomon D. Self-healing polymeric materials: a review of recent developments. Prog Polym Sci 2008;33:479-522.

[9] van der Zwaag S, Van Dijk N, Jonkers H, Mookhoek S, Sloof W. Self-healing behaviour in man-made engineering materials: bioinspired but taking into account their intrinsic character. Philos Trans A 2009;367:1689-704.

[10] Amendola V, Meneghetti M. Self-healing at the nanoscale. Nanoscale 2009;1:74-88.

[11] Hager MD, Greil P, Leyens C, van der Zwaag Self-Healing Materials. Adv Mater 2010;22:5424-30. 
[12] Blaiszik B, Kramer S, Olugebefola S, Moore JS, Sottos NR, White SR. Self-healing polymers and composites. Annu Rev Mater Res 2010;40:179-211.

[13] Syrett JA, Becer CR, Haddleton DM. Self-healing and self-mendable polymers. Polym Chem 2010;1:978-87.

[14] Mauldin T, Kessler M. Self-healing polymers and composites. Int Mater Rev 2010;55:317-46.

[15] Brochu AB, Craig SL, Reichert WM. Self-healing biomaterials. J Biomed Mater Res A 2011;96:492-506.

[16] Leng J, Lan X, Liu Y, Du S. Shape-memory polymers and their composites: stimulus methods and applications. Prog Mater Sci 2011;56:1077-135.

[17] Sun L, Huang W, Ding Z, Zhao Y, Wang C, Purnawali H, Tang C. Stimulus-responsive shape memory materials: a review. Mater Des 2012;33:577-640.

[18] Guimard NK, Oehlenschlaeger KK, Zhou J, Hilf S, Schmidt FG, Barner-Kowollik C. Current Trends in the Field of Self-Healing Materials. Macromol Chem Phys 2012;213:131-43.

[19] Guarino V, Gloria A, Raucci MG, De Santis R, Ambrosio L. Bio-inspired composite and cell instructive platforms for bone regeneration. Int Mater Rev 2012;57:256-75.

[20] Habault D, Zhang H, Zhao Y. Light-triggered self-healing and shape-memory polymers. Chem Soc Rev 2013;42:7244-56.

[21] Herbst F, Döhler D, Michael P, Binder WH. Self-Healing Polymers via Supramolecular Forces. Macromol Rapid Commun 2013;34:203-20.

[22] Garcia SJ. Effect of polymer architecture on the intrinsic self-healing character of polymers. Eur Polym J 2014;53:118-25.

[23] Meng H, Li G. A review of stimuli-responsive shape memory polymer composites. Polymer 2013;54:2199-221.

[24] Gould P. Self-help for ailing structures. Mater Today 2003;6:44-9.

[25] Billiet S, Hillewaere XK, Teixeira RF, Du Prez FE. Chemistry of Crosslinking Processes for Self-Healing Polymers. Macromol Rapid Commun 2013;34:290-309.

[26] Aissa B, Therriault D, Haddad E, Jamroz W. Self-healing materials systems: overview of major approaches and recent developed technologies. Adv Mater Sci Eng 2012;2012:854203/1-17. 
[27] Zhang MQ, Rong MZ. Theoretical consideration and modeling of self-healing polymers. J Polym Sci Part B Polym Phys 2012;50:229-41.

[28] Hu J, Zhu Y, Huang H, Lu J. Recent advances in shape-memory polymers: Structure, mechanism, functionality, modeling and applications. Prog Polym Sci 2012;37:1720-63.

[29] Zhang M, Rong M. Design and synthesis of self-healing polymers. Sci China Chem 2012;55:648-76.

[30] Jin H, Miller GM, Sottos NR, White SR. Fracture and fatigue response of a self-healing epoxy adhesive. Polymer 2011;52:1628-34.

[31] Murphy EB, Wudl F. The world of smart healable materials. Prog Polym Sci 2010;35:223-51.

[32] Meng H, Li G. Reversible switching transitions of stimuli-responsive shape changing polymers. J Mater Chem A 2013;1:7838-65.

[33] Samadzadeh M, Boura SH, Peikari M, Kasiriha S, Ashrafi A. A review on self-healing coatings based on micro/nanocapsules. Prog Org Coat 2010;68:159-64.

[34] Burattini S, Greenland BW, Chappell D, Colquhoun HM, Hayes W. Healable polymeric materials: a tutorial review. Chem Soc Rev 2010;39:1973-85.

[35] Ghosh SK. Self-healing materials: fundamentals, design strategies, and applications. Weinheim: Wiley-VCH 2009. 285 pp.

[36] Yuan Y, Yin T, Rong M, Zhang M. Self healing in polymers and polymer composites. Concepts, realization and outlook: a review. Express Polym Lett 2008;2:238-50.

[37] Trask R, Williams H, Bond I. Self-healing polymer composites: mimicking nature to enhance performance. Bioinspir Biomim 2007;2:1-9.

[38] Balazs AC. Modeling self-healing materials. Mater Today 2007;10:18-23.

[39] Yang Y, Urban MW. Self-healing polymeric materials. Chem Soc Rev 2013;42:7446-67.

[40] Pretsch T. Review on the functional determinants and durability of shape memory polymers. Polymers 2010;2:120-58.

[41] Hearon K, Singhal P, Horn J, Small IV W, Olsovsky C, Maitland KC, Wilson TS, Maitland DJ. Porous shape-memory polymers. Polym Rev 2013;53:41-75.

[42] Meng H, Mohamadian H, Stubblefield M, Jerro D, Ibekwe S, Pang SS, Li G. Various shape memory effects of stimuli-responsive shape memory polymers. Smart Mater Struct 2013;22:093001/1-23.

[43] Zhang MQ, Rong MZ. Self-healing polymers and polymer composites. Hoboken: John Wiley \& Sons Inc, 2011. 448 pp. 
[44] van der Zwaag S, editor. Self healing materials: an alternative approach to 20 centuries of materials science. Dordrecht: Springer, 2007. 388 pp.

[45] Amendola V, Meneghetti M. Self-healing at the nanoscale: mechanisms and key concepts of natural and artificial systems. Boca Raton: CRC Press, 2012. 447 pp.

[46] Nosonovsky M, Rohatgi PK. Biomimetics in materials science: self-healing, selflubricating, and self-cleaning materials. New York: Springer, 2011. 409 pp.

[47] Li G. Self-Healing Composites: Shape Memory Polymer Based Structures. West Sussex: John Wiley \& Sons Ltd, 2014.392 pp,.

[48] Binder WH. Self-healing Polymers: From Principles to Applications. Weinheim: WileyVCH, 2013. 444 pp.

[49] Pascault JP, Williams RJ. Epoxy polymers. Weinheim: Wiley-VCH, 2009. 357 pp.

[50] Hillewaere XK, Du Prez FE. Fifteen chemistries for autonomous external self-healing polymers and composites. Prog Polym Sci 2015;49-50:121-153.

[51] Huang H, Ye G, Damidot D. Characterization and quantification of self-healing behaviors of microcracks due to further hydration in cement paste. Cement Concrete Res 2013;52:71-81.

[52] van Tittelboom K, De Belie N, Lehmann F, Grosse C. Use of acoustic emission analysis to evaluate the self-healing capability of concrete. In: Büyüköztürk $O$, Taşdemir MA, Güneş O, Akkaya Y, editors. Nondestructive Testing of Materials and Structures. Dordrecht: Springer, 2013. p. 51-7.

[53] Wang J, Van Tittelboom K, De Belie N, Verstraete W. Use of silica gel or polyurethane immobilized bacteria for self-healing concrete. Constr Build Mater 2012;26:532-40.

[54] Wiktor V, Jonkers HM. Quantification of crack-healing in novel bacteria-based selfhealing concrete. Cement Concrete Compos 2011;33:763-70.

[55] Borisova D, Akçakayıran D, Schenderlein M, Möhwald H, Shchukin DG. NanocontainerBased Anticorrosive Coatings: Effect of the Container Size on the Self-Healing Performance. Adv Funct Mater 2013;23:3799-812.

[56] Wang Y, Joyce HJ, Gao Q, Liao X, Tan HH, Zou J, Ringer SP, Shan Z, Jagadish C. Selfhealing of fractured GaAs nanowires. Nano Lett 2011;11:1546-9.

[57] Li GL, Zheng Z, Möhwald H, Shchukin DG. Silica/Polymer Double-Walled Hybrid Nanotubes: Synthesis and Application as Stimuli-Responsive Nanocontainers in SelfHealing Coatings. ACS Nano 2013;7:2470-8. 
[58] Gelain F, Silva D, Caprini A, Taraballi F, Natalello A, Villa O, Nam KT, Zuchkermann RN, Doglia SM, Vescovi A. BMHP1-derived self-assembling peptides: hierarchically assembled structures with self-healing propensity and potential for tissue engineering applications. ACS Nano 2011;5:1845-59.

[59] Wool R, O'connor K. A theory crack healing in polymers. J Appl Phys 1981;52:5953-63.

[60] Deng G, Tang C, Li F, Jiang H, Chen Y. Covalent Cross-Linked Polymer Gels with Reversible Sol- Gel Transition and Self-Healing Properties. Macromolecules 2010;43:1191-4.

[61] He L, Fullenkamp DE, Rivera JG, Messersmith PB. pH responsive self-healing hydrogels formed by boronate-catechol complexation. Chem Commun 2011;47:7497-9.

[62] Zhang M, Xu D, Yan X, Chen J, Dong S, Zheng B, Huang F. Self-Healing Supramolecular Gels Formed by Crown Ether Based Host-Guest Interactions. Angew Chem 2012;124:7117-21.

[63] Phadke A, Zhang C, Arman B, Hsu CC, Mashelkar RA, Lele AK, Tauber MJ, Arya G, Varghese S. Rapid self-healing hydrogels. Proc Natl Acad Sci USA 2012;109:4383-8.

[64] Krogsgaard M, Behrens MA, Pedersen JS, Birkedal H. Self-healing mussel-inspired multi-pH-responsive hydrogels. Biomacromolecules 2013;14:297-301.

[65] Reisch A, Roger E, Phoeung T, Antheaume C, Orthlieb C, Boulmedais F, Lavalle P, Schlenoff JB, Frisch B, Schaaf P. On the Benefits of Rubbing Salt in the Cut: SelfHealing of Saloplastic PAA/PAH Compact Polyelectrolyte Complexes. Adv Mater 2014;26:2547-51.

[66] Williams KA, Boydston AJ, Bielawski CW. Towards electrically conductive, self-healing materials. J R Soc Interface 2007;4:359-62.

[67] Park JS, Takahashi K, Guo Z, Wang Y, Bolanos E, Hamann-Schaffner C, Murphy E, Wudl F, Hahn HT. Towards development of a self-healing composite using a mendable polymer and resistive heating. J Compos Mater 2008;42:2869-81.

[68] Zhang Y, Broekhuis AA, Picchioni F. Thermally self-healing polymeric materials: the next step to recycling thermoset polymers. Macromolecules 2009;42:1906-12.

[69] Syrett JA, Mantovani G, Barton WR, Price D, Haddleton DM. Self-healing polymers prepared via living radical polymerisation. Polym Chem 2010;1:102-6.

[70] Wang H, Xue Y, Ding J, Feng L, Wang X, Lin T. Durable, Self-Healing Superhydrophobic and Superoleophobic Surfaces from Fluorinated-Decyl Polyhedral 
Oligomeric Silsesquioxane and Hydrolyzed Fluorinated Alkyl Silane. Angew Chem Int Ed 2011;50:11433-6.

[71] Yuan Ce, Rong MZ, Zhang MQ, Zhang ZP, Yuan YC. Self-healing of polymers via synchronous covalent bond fission/radical recombination. Chem Mater 2011;23:5076-81.

[72] Canadell J, Goossens H, Klumperman B. Self-healing materials based on disulfide links. Macromolecules 2011;44:2536-41.

[73] Haraguchi K, Uyama K, Tanimoto H. Self-healing in Nanocomposite Hydrogels. Macromol Rapid Commun 2011;32:1253-8.

[74] Bode S, Zedler L, Schacher FH, Dietzek B, Schmitt M, Popp J, Hager MD, Schubert US. Self-Healing Polymer Coatings Based on Crosslinked Metallosupramolecular Copolymers. Adv Mater 2013;25:1634-8.

[75] South AB, Lyon LA. Autonomic Self-Healing of Hydrogel Thin Films. Angew Chem 2010;122:779-83.

[76] Wang X, Liu F, Zheng X, Sun J. Water-Enabled Self-Healing of Polyelectrolyte Multilayer Coatings. Angew Chem Int Ed 2011;50:11378-81.

[77] Burnworth M, Tang L, Kumpfer JR, Duncan AJ, Beyer FL, Fiore GL, Rowan SJ, Weder C. Optically healable supramolecular polymers. Nature 2011;472:334-7.

[78] Sottos NR, Moore JS. Materials chemistry: spot-on healing. Nature 2011;472:299-300.

[79] Amamoto Y, Kamada J, Otsuka H, Takahara A, Matyjaszewski K. Repeatable Photoinduced Self-Healing of Covalently Cross-Linked Polymers through Reshuffling of Trithiocarbonate Units. Angew Chem 2011;123:1698-701.

[80] Ghosh B, Urban MW. Self-repairing oxetane-substituted chitosan polyurethane networks. Science 2009;323:1458-60.

[81] Froimowicz P, Frey H, Landfester K. Towards the Generation of Self-Healing Materials by Means of a Reversible Photo-induced Approach. Macromol Rapid Commun 2011;32:468-73.

[82] Amamoto Y, Otsuka H, Takahara A, Matyjaszewski K. Self-Healing of Covalently Cross-Linked Polymers by Reshuffling Thiuram Disulfide Moieties in Air under Visible Light. Adv Mater 2012;24:3975-80.

[83] Ling J, Rong MZ, Zhang MQ. Photo-stimulated self-healing polyurethane containing dihydroxyl coumarin derivatives. Polymer 2012;53:2691-8. 
[84] Yu X, Cao X, Chen L, Lan H, Liu B, Yi T. Thixotropic and self-healing triggered reversible rheology switching in a peptide-based organogel with a cross-linked nano-ring pattern. Soft Matter 2012;8:3329-34.

[85] Chuo TW, Wei TC, Liu YL. Electrically driven self-healing polymers based on reversible guest-host complexation of $\beta$-cyclodextrin and ferrocene. J Polym Sci Part A Polym Chem 2013;51:3395-403.

[86] Wietor JL, Sijbesma RP. A Self-Healing Elastomer. Angew Chem Int Ed 2008;47:8161-3.

[87] Cordier P, Tournilhac F, Soulié-Ziakovic C, Leibler L. Self-healing and thermoreversible rubber from supramolecular assembly. Nature 2008;451:977-80.

[88] Kolmakov GV, Matyjaszewski K, Balazs AC. Harnessing labile bonds between nanogel particles to create self-healing materials. ACS Nano 2009;3:885-92.

[89] Yoon JA, Kamada J, Koynov K, Mohin J, Nicolaÿ R, Zhang Y, Balazs AC, Kowalewski T, Matyjaszewski K. Self-healing polymer films based on thiol-disulfide exchange reactions and self-healing kinetics measured using atomic force microscopy. Macromolecules 2012;45:142-9.

[90] van Gemert GM, Peeters JW, Söntjens SH, Janssen HM, Bosman AW. Self-Healing Supramolecular Polymers In Action. Macromol Chem Phys 2012;213:234-42.

[91] Zhang A, Yang L, Lin Y, Yan L, Lu H, Wang L. Self-healing supramolecular elastomers based on the multi-hydrogen bonding of low-molecular polydimethylsiloxanes: Synthesis and characterization. J Appl Polym Sci 2013;129:2435-42.

[92] Vidyasagar A, Handore K, Sureshan KM. Soft Optical Devices from Self-Healing Gels Formed by Oil and Sugar-Based Organogelators. Angew Chem Int Ed 2011;50:8021-4.

[93] Tuncaboylu DC, Sari M, Oppermann W, Okay O. Tough and self-healing hydrogels formed via hydrophobic interactions. Macromolecules 2011;44:4997-5005.

[94] Akay G, Hassan-Raeisi A, Tuncaboylu DC, Orakdogen N, Abdurrahmanoglu S, Oppermann W, Okay O. Self-healing hydrogels formed in catanionic surfactant solutions. Soft Matter 2013;9:2254-61.

[95] Nakahata M, Takashima Y, Yamaguchi H, Harada A. Redox-responsive self-healing materials formed from host-guest polymers. Nat Commun 2011;2:511/1-6.

[96] Kakuta T, Takashima Y, Nakahata M, Otsubo M, Yamaguchi H, Harada A. Preorganized Hydrogel: Self-Healing Properties of Supramolecular Hydrogels Formed by 
Polymerization of Host-Guest-Monomers that Contain Cyclodextrins and Hydrophobic Guest Groups. Adv Mater 2013;25:2849-53.

[97] Terech P, Yan M, Maréchal M, Royal G, Galvez J, Velu SK. Characterization of strain recovery and "self-healing" in a self-assembled metallo-gel. Phys Chem Chem Phys $2013 ; 15: 7338-44$.

[98] Imato K, Nishihara M, Kanehara T, Amamoto Y, Takahara A, Otsuka H. Self-Healing of Chemical Gels Cross-Linked by Diarylbibenzofuranone-Based Trigger-Free Dynamic Covalent Bonds at Room Temperature. Angew Chem Int Ed 2012;51:1138-42.

[99] Zeng C, Seino H, Ren J, Hatanaka K, Yoshie N. Bio-Based Furan Polymers with SelfHealing Ability. Macromolecules 2013;46:1794-802.

[100] Kalista Jr SJ, Ward TC, Oyetunji Z. Self-healing of poly (ethylene-co-methacrylic acid) copolymers following projectile puncture. Mech Adv Mater Struct 2007;14:391-7.

[101] Kalista SJ, Ward TC. Thermal characteristics of the self-healing response in poly (ethylene-co-methacrylic acid) copolymers. J R Soc Interface 2007;4:405-11.

[102] Varley RJ, van der Zwaag S. Development of a quasi-static test method to investigate the origin of self-healing in ionomers under ballistic conditions. Polym Test 2008;27:11-9.

[103] Varley RJ, van der Zwaag S. Towards an understanding of thermally activated selfhealing of an ionomer system during ballistic penetration. Acta Mater 2008;56:5737-50.

[104] Varley RJ, Shen S, van der Zwaag S. The effect of cluster plasticisation on the self healing behaviour of ionomers. Polymer 2010;51:679-86.

[105] Rahman MA, Sartore L, Bignotti F, Di Landro L. Autonomic Self-Healing in Epoxidized Natural Rubber. ACS Appl Mater Interfaces 2013;5:1494-502.

[106] Rahman MA, Spagnoli G, Grande AM, Di Landro L. Role of Phase Morphology on the Damage Initiated Self-healing Behavior of Ionomer Blends. Macromol Mater Eng 2013;298:1350-64.

[107] Hohlbein N, Shaaban A, Schmidt A. Remote-controlled activation of self-healing behavior in magneto-responsive ionomeric composites. Polymer 2015;69:301-9.

[108] Saha S, Bachl J, Kundu T, Díaz DD, Banerjee R. Amino acid-based multiresponsive lowmolecular weight metallohydrogels with load-bearing and rapid self-healing abilities. Chem Commun 2014;50:3004-6.

[109] Chen Y, Guan Z. Multivalent hydrogen bonding block copolymers self-assemble into strong and tough self-healing materials. Chem Commun 2014;50:10868-70. 
[110] Zhang Y, Qi YH, Zhang ZP. The influence of 2, 4-toluene diisocyanate content on the intrinsic self-healing performance of polyurethane at room-temperature. J Polym Res $2015 ; 22: 1-6$.

[111] Chen Y, Guan Z. Self-healing thermoplastic elastomer brush copolymers having a glassy polymethylmethacrylate backbone and rubbery polyacrylate-amide brushes. Polymer 2015;69:249-54.

[112] Döhler D, Peterlik H, Binder WH. A dual crosslinked self-healing system: Supramolecular and covalent network formation of four-arm star polymers. Polymer 2015;69:264-73.

[113] Wang L, Di S, Wang W, Zhou S. Self-healing and shape memory capabilities of coppercoordination polymer network. ASC Adv 2015;5:28896-900.

[114] Engel T, Kickelbick G. Furan-Modified Spherosilicates as Building Blocks for SelfHealing Materials. Eur J Inorg Chem 2014 doi: 10.1002/ejic.201402551.

[115] Nguyen LTT, Truong TT, Nguyen HT, Le L, Nguyen VQ, Van Le T, Luu AT. Healable shape memory (thio) urethane thermosets. Polym Chem 2015;6:3143-54.

[116] Oehlenschlaeger KK, Mueller JO, Brandt J, Hilf S, Lederer A, Wilhelm M, Graf R, Coote ML, Schmidt FG, Barner-Kowollik C. Adaptable Hetero Diels-Alder Networks for Fast Self-Healing under Mild Conditions. Adv Mater 2014;26:3561-6.

[117] Yuan Ce, Rong MZ, Zhang MQ. Self-healing polyurethane elastomer with thermally reversible alkoxyamines as crosslinkages. Polymer 2014;55:1782-91.

[118] Yu C, Wang CF, Chen S. Robust Self-Healing Host-Guest Gels from Magnetocaloric Radical Polymerization. Adv Funct Mater 2014;24:1235-42.

[119] Kakuta T, Takashima Y, Sano T, Nakamura T, Kobayashi Y, Yamaguchi H, Harada A. Adhesion between Semihard Polymer Materials Containing Cyclodextrin and Adamantane Based on Host-Guest Interactions. Macromolecules 2015;48:732-8.

[120] Cash JJ, Kubo T, Bapat AP, Sumerlin BS. Room-Temperature Self-Healing Polymers Based on Dynamic-Covalent Boronic Esters. Macromolecules 2015;48:2098-106.

[121] Wei H, Du S, Liu Y, Zhao H, Chen C, Li Z, Lin J, Zhang Y, Zhang J, Wan X. Tunable, luminescent, and self-healing hybrid hydrogels of polyoxometalates and triblock copolymers based on electrostatic assembly. Chem Commun 2014;50:1447-50.

[122] Neal JA, Mozhdehi D, Guan Z. Enhancing Mechanical Performance of a Covalent SelfHealing Material by Sacrificial Noncovalent Bonds. J Am Chem Soc 2015;137:4846-50. 
[123] Kawata Y, Yamamoto T, Kihara H, Ohno K. Dual Self-Healing Abilities of Composite Gels Consisting of Polymer-Brush-Afforded Particles and an Azobenzene-Doped Liquid Crystal. ACS Appl Mater Interfaces 2015;7:4185-91.

[124] Zhang X, He J. Hydrogen-Bonding-Supported Self-Healing Antifogging Thin Films. Sci Rep 2015 doi:10.1038/srep09227.

[125] Kuhl N, Bode S, Bose RK, Vitz J, Seifert A, Hoeppener S, Garcia SJ, Spange S, van der Zwaag S, Hager MD, Schubert US. Acylhydrazones as Reversible Covalent Crosslinkers for Self-Healing Polymers. Adv Funct Mater 2015;25:3295-301.

[126] Ji G, Ouyang Z, Li G. On the interfacial constitutive laws of mixed mode fracture with various adhesive thicknesses. Mech Mater 2012;47:24-32.

[127] Urban MW. Self-Repairing Polymeric Materials. Kirk-Othmer Encyclopedia of Chemical Technology 2015 doi: 10.1002/0471238961.koe00003.

[128] Yang Y, Ding X, Urban MW. Chemical and Physical Aspects of Self-Healing Materials. Prog Polym Sci 2015;49-50:34-59.

[129] Reisch A, Tirado P, Roger E, Boulmedais F, Collin D, Voegel JC, Frisch B, Schaaf P, Schlenoff JB. Compact Saloplastic Poly (Acrylic Acid)/Poly (Allylamine) Complexes: Kinetic Control Over Composition, Microstructure, and Mechanical Properties. Adv Funct Mater 2013;23:673-82.

[130] Lu YX, Tournilhac F, Leibler L, Guan Z. Making insoluble polymer networks malleable via olefin metathesis. J Am Chem Soc 2012;134:8424-7.

[131] Lu YX, Guan Z. Olefin Metathesis for Effective Polymer Healing via Dynamic Exchange of Strong Carbon-Carbon Double Bonds. J Am Chem Soc 2012;134:14226-31.

[132] Taynton P, Yu K, Shoemaker RK, Jin Y, Qi HJ, Zhang W. Heat-or Water-Driven Malleability in a Highly Recyclable Covalent Network Polymer. Adv Mater 2014;26:3938-42.

[133] Montarnal D, Capelot M, Tournilhac F, Leibler L. Silica-like malleable materials from permanent organic networks. Science 2011;334:965-8.

[134] Bowman CN, Kloxin CJ. Covalent Adaptable Networks: Reversible Bond Structures Incorporated in Polymer Networks. Angew Chem Int Ed 2012;51:4272-4.

[135] Cheng C, Bai X, Zhang X, Li H, Huang Q, Tu Y. Self-healing polymers based on a photo-active reversible addition-fragmentation chain transfer (RAFT) agent. J Polym Res $2015 ; 22: 1-8$. 
[136] Inglis AJ, Nebhani L, Altintas O, Schmidt FG, Barner-Kowollik C. Rapid Bonding/Debonding on Demand: Reversibly Cross-Linked Functional Polymers via Diels- Alder Chemistry. Macromolecules 2010;43:5515-20.

[137] Oehlenschlaeger KK, Guimard NK, Brandt J, Mueller JO, Lin CY, Hilf S, Lederer A, Coote M, Schmidt FG, Barner-Kowollik C. Fast and catalyst-free hetero-Diels-Alder chemistry for on demand cyclable bonding/debonding materials. Polym Chem 2013;4:4348-55.

[138] Zhong Y, Wang X, Zheng Z, Du P. Polyether-maleimide-based crosslinked self-healing polyurethane with Diels-Alder bonds. J Appl Polym Sci 2015 doi: 10.1002/app.41944.

[139] Faghihnejad A, Feldman KE, Yu J, Tirrell MV, Israelachvili JN, Hawker CJ, Kramer EJ, Zeng H. Adhesion and Surface Interactions of a Self-Healing Polymer with Multiple Hydrogen-Bonding Groups. Adv Funct Mater 2014;24:2322-33.

[140] Miyamae K, Nakahata M, Takashima Y, Harada A. Self-healing, expansion-contraction, and shape memory properties of a preorganized supramolecular hydrogel through hostguest interactions. Angew Chem 2015;127:9112-5.

[141] Mukhopadhyay P, Fujita N, Takada A, Kishida T, Shirakawa M, Shinkai S. Regulation of a Real-Time Self-Healing Process in Organogel Tissues by Molecular Adhesives. Angew Chem Int Ed 2010;49:6338-42.

[142] Zhan J, Zhang M, Zhou M, Liu B, Chen D, Liu Y, Chen Q, Qiu H, Yin S. A MultipleResponsive Self-Healing Supramolecular Polymer Gel Network Based on Multiple Orthogonal Interactions. Macromol Rapid Commun 2014;35:1424-9.

[143] Urban MW. Stratification, stimuli-responsiveness, self-healing, and signaling in polymer networks. Prog Polym Sci 2009;34:679-87.

[144] Diesendruck CE, Sottos NR, Moore JS, White SR. Biomimetic Self-Healing. Angew Chem Int Ed 2015 doi: 10.1002/anie.201500484.

[145] Yuan L, Liang G, Xie J, Li L, Guo J. Preparation and characterization of poly (ureaformaldehyde) microcapsules filled with epoxy resins. Polymer 2006;47:5338-49.

[146] Blaiszik B, Caruso M, Mcllroy D, Moore J, White S, Sottos N. Microcapsules filled with reactive solutions for self-healing materials. Polymer 2009;50:990-7.

[147] Caruso MM, Blaiszik BJ, Jin H, Schelkopf SR, Stradley DS, Sottos NR, White SR, Moore JS. Robust, double-walled microcapsules for self-healing polymeric materials. ACS Appl Mater Interfaces 2010;2:1195-9. 
[148] Wang R, Li H, Hu H, He X, Liu W. Preparation and characterization of self-healing microcapsules with poly (urea-formaldehyde) grafted epoxy functional group shell. J Appl Polym Sci 2009;113:1501-6.

[149] Tong XM, Zhang M, Wang MS, Fu Y. Effects of surface modification of self-healing poly (melamine-urea-formaldehyde) microcapsules on the properties of unsaturated polyester composites. J Appl Polym Sci 2013;127:3954-61.

[150] Li Q, Mishra AK, Kim NH, Kuila T, Lau KT, Lee JH. Effects of processing conditions of poly (methylmethacrylate) encapsulated liquid curing agent on the properties of selfhealing composites. Composites B 2013;49:6-15.

[151] Blaiszik B, Sottos N, White S. Nanocapsules for self-healing materials. Compos Sci Technol 2008;68:978-86.

[152] Li GL, Schenderlein M, Men Y, Möhwald H, Shchukin DG. Monodisperse Polymeric Core-Shell Nanocontainers for Organic Self-Healing Anticorrosion Coatings. Adv Mater Interfaces 2014;1:1300019/1-6.

[153] Blaiszik B, Jones A, Sottos N, White S. Microencapsulation of gallium-indium (Ga-In) liquid metal for self-healing applications. J Microencapsul 2014;31:350-4.

[154] Kang S, Jones AR, Moore JS, White SR, Sottos NR. Microencapsulated Carbon Black Suspensions for Restoration of Electrical Conductivity. Adv Funct Mater 2014;24:294756.

[155] Tao Y, Chang Y, Tao Y, Yang Z, Wu H. Self-healing isotropical conductive adhesives filled with Ag nanowires. Mater Chem Phys 2014;148:778-82.

[156] Zhao Y, Zhang W, Liao LP, Wang SJ, Li WJ. Self-healing coatings containing microcapsule. Appl Surf Sci 2012;258:1915-8.

[157] Fereidoon A, Ahangari MG, Jahanshahi M. Effect of nanoparticles on the morphology and thermal properties of self-healing poly (urea-formaldehyde) microcapsules. J Polym Res 2013;20:1-8.

[158] Caruso MM, Blaiszik BJ, White SR, Sottos NR, Moore JS. Full Recovery of Fracture Toughness Using a Nontoxic Solvent-Based Self-Healing System. Adv Funct Mater 2008; 18:1898-904.

[159] Yang J, Keller MW, Moore JS, White SR, Sottos NR. Microencapsulation of isocyanates for self-healing polymers. Macromolecules 2008;41:9650-5. 
[160] Liu X, Sheng X, Lee JK, Kessler MR, Kim JS. Rheokinetic evaluation of self-healing agents polymerized by Grubbs catalyst embedded in various thermosetting systems. Compos Sci Technol 2009;69:2102-7.

[161] Andersson C, Järnström L, Fogden A, Mira I, Voit W, Zywicki S, Bartkowiak A. Preparation and incorporation of microcapsules in functional coatings for self-healing of packaging board. Packag Technol Sci 2009;22:275-91.

[162] Szabó T, Molnár-Nagy L, Bognár J, Nyikos L, Telegdi J. Self-healing microcapsules and slow release microspheres in paints. Prog Org Coat 2011;72:52-7.

[163] McIlroy DA, Blaiszik BJ, Caruso MM, White SR, Moore JS, Sottos NR. Microencapsulation of a reactive liquid-phase amine for self-healing epoxy composites. Macromolecules 2010;43:1855-9.

[164] Jadhav RS, Hundiwale DG, Mahulikar PP. Synthesis and characterization of phenolformaldehyde microcapsules containing linseed oil and its use in epoxy for self-healing and anticorrosive coating. J Appl Polym Sci 2011;119:2911-6.

[165] Samadzadeh M, Boura SH, Peikari M, Ashrafi A, Kasiriha M. Tung oil: An autonomous repairing agent for self-healing epoxy coatings. Prog Org Coat 2011;70:383-7.

[166] Wang HP, Yuan YC, Rong MZ, Zhang MQ. Self-healing of thermoplastics via living polymerization. Macromolecules 2010;43:595-8.

[167] Yao L, Yuan YC, Rong MZ, Zhang MQ. Self-healing linear polymers based on RAFT polymerization. Polymer 2011;52:3137-45.

[168] Yuan YC, Rong MZ, Zhang MQ, Yang GC. Study of factors related to performance improvement of self-healing epoxy based on dual encapsulated healant. Polymer 2009;50:5771-81.

[169] Caruso MM, Delafuente DA, Ho V, Sottos NR, Moore JS, White SR. Solvent-promoted self-healing epoxy materials. Macromolecules 2007;40:8830-2.

[170] Keller M, White S, Sottos N. Torsion fatigue response of self-healing poly (dimethylsiloxane) elastomers. Polymer 2008;49:3136-45.

[171] White SR, Sottos N, Geubelle P, Moore J, Kessler MR, Sriram SR, Brown EN, Viswanathan S. Autonomic healing of polymer composites. Nature 2001;409:794-7.

[172] Kessler M, Sottos N, White SR. Self-healing structural composite materials. Composites A $2003 ; 34: 743-53$. 
[173] Manfredi E, Michaud V. Packing and permeability properties of E-glass fibre reinforcements functionalised with capsules for self-healing applications. Composites A 2014;66:94-102.

[174] Jones AS, Rule JD, Moore JS, White SR, Sottos NR. Catalyst morphology and dissolution kinetics of self-healing polymers. Chem Mater 2006;18:1312-7.

[175] Jin H, Miller GM, Pety SJ, Griffin AS, Stradley DS, Roach D, Sottos N, White S. Fracture behavior of a self-healing, toughened epoxy adhesive. Int J Adhes Adhes 2013;44:157-65.

[176] Patel AJ, Sottos NR, Wetzel ED, White SR. Autonomic healing of low-velocity impact damage in fiber-reinforced composites. Composites A 2010;41:360-8.

[177] Rule JD, Brown EN, Sottos NR, White SR, Moore JS. Wax-Protected Catalyst Microspheres for Efficient Self-Healing Materials. Adv Mater 2005;17:205-8.

[178] Mauldin TC, Rule JD, Sottos NR, White SR, Moore JS. Self-healing kinetics and the stereoisomers of dicyclopentadiene. J R Soc Interface 2007;4:389-93.

[179] Rule JD, Sottos NR, White SR. Effect of microcapsule size on the performance of selfhealing polymers. Polymer 2007;48:3520-9.

[180] Wilson GO, Moore JS, White SR, Sottos NR, Andersson HM. Autonomic healing of epoxy vinyl esters via ring opening metathesis polymerization. Adv Funct Mater 2008;18:44-52.

[181] Brown EN, White SR, Sottos NR. Retardation and repair of fatigue cracks in a microcapsule toughened epoxy composite-Part I: Manual infiltration. Compos Sci Technol 2005;65:2466-73.

[182] Brown EN, White SR, Sottos NR. Retardation and repair of fatigue cracks in a microcapsule toughened epoxy composite—Part II: In situ self-healing. Compos Sci Technol 2005;65:2474-80.

[183] Jones A, Rule J, Moore J, Sottos N, White S. Life extension of self-healing polymers with rapidly growing fatigue cracks. J R Soc Interface 2007;4:395-403.

[184] Wilson GO, Caruso MM, Reimer NT, White SR, Sottos NR, Moore JS. Evaluation of ruthenium catalysts for ring-opening metathesis polymerization-based self-healing applications. Chem Mater 2008;20:3288-97.

[185] Kamphaus JM, Rule JD, Moore JS, Sottos NR, White SR. A new self-healing epoxy with tungsten (VI) chloride catalyst. J R Soc Interface 2008;5:95-103. 
[186] Yin T, Rong MZ, Zhang MQ, Yang GC. Self-healing epoxy composites-preparation and effect of the healant consisting of microencapsulated epoxy and latent curing agent. Compos Sci Technol 2007;67:201-12.

[187] Yin T, Zhou L, Rong MZ, Zhang MQ. Self-healing woven glass fabric/epoxy composites with the healant consisting of micro-encapsulated epoxy and latent curing agent. Smart Mater Struct 2008;17:015019/1-8.

[188] Yin T, Rong MZ, Wu J, Chen H, Zhang MQ. Healing of impact damage in woven glass fabric reinforced epoxy composites. Composites A 2008;39:1479-87.

[189] Yin T, Rong MZ, Zhang MQ, Zhao JQ. Durability of self-healing woven glass fabric/epoxy composites. Smart Mater Struct 2009;18:074001/1-7.

[190] Song YK, Jo YH, Lim YJ, Cho SY, Yu HC, Ryu BC, Lee S, Chung C. Sunlight-Induced Self-Healing of a Microcapsule-Type Protective Coating. ACS Appl Mater Interfaces 2013;5:1378-84.

[191] Xiao DS, Yuan YC, Rong MZ, Zhang MQ. A Facile Strategy for Preparing Self-Healing Polymer Composites by Incorporation of Cationic Catalyst-Loaded Vegetable Fibers. Adv Funct Mater 2009;19:2289-96.

[192] Xiao DS, Yuan YC, Rong MZ, Zhang MQ. Self-healing epoxy based on cationic chain polymerization. Polymer 2009;50:2967-75.

[193] Ye XJ, Song YX, Zhu Y, Yang GC, Rong MZ, Zhang MQ. Self-healing epoxy with ultrafast and heat-resistant healing system processable at elevated temperature. Compos Sci Technol 2014;104:40-6.

[194] Cho SH, White SR, Braun PV. Self-Healing Polymer Coatings. Adv Mater 2009;21:6459.

[195] Mangun C, Mader A, Sottos N, White S. Self-healing of a high temperature cured epoxy using poly (dimethylsiloxane) chemistry. Polymer 2010;51:4063-8.

[196] Beiermann B, Keller M, Sottos N. Self-healing flexible laminates for resealing of puncture damage. Smart Mater Struct 2009;18:085001/1-7.

[197] Keller MW, White SR, Sottos NR. A Self-Healing Poly (Dimethyl Siloxane) Elastomer. Adv Funct Mater 2007;17:2399-404.

[198] Jin H, Mangun CL, Stradley DS, Moore JS, Sottos NR, White SR. Self-healing thermoset using encapsulated epoxy-amine healing chemistry. Polymer 2012;53:581-7. 
[199] Jin H, Mangun CL, Griffin AS, Moore JS, Sottos NR, White SR. Thermally Stable Autonomic Healing in Epoxy using a Dual-Microcapsule System. Adv Mater 2014;26:282-7.

[200] Tao Y, Chang Y, Tao Y, Wu H, Yang Z. Self-healing Ag/epoxy electrically conductive adhesive using encapsulated epoxy-amine healing chemistry. J Appl Polym Sci 2015 doi: 10.1002/app.41483.

[201] Zhang H, Wang P, Yang J. Self-healing epoxy via epoxy-amine chemistry in dual hollow glass bubbles. Compos Sci Technol 2014;94:23-9.

[202] Cho SH, Andersson HM, White SR, Sottos NR, Braun PV. Polydimethylsiloxane-Based Self-Healing Materials. Adv Mater 2006;18:997-1000.

[203] Lee J, Bhattacharyya D, Zhang M, Yuan Y. Fracture behaviour of a self-healing microcapsule-loaded epoxy system. Express Polym Lett 2011;5:246-53.

[204] Gragert M, Schunack M, Binder WH. Azide/Alkyne-“Click”-Reactions of Encapsulated Reagents: Toward Self-Healing Materials. Macromol Rapid Commun 2011;32:419-25.

[205] Schunack M, Gragert M, Döhler D, Michael P, Binder WH. Low-Temperature Cu (I)Catalyzed "Click" Reactions for Self-Healing Polymers. Macromol Chem Phys 2012;213:205-14.

[206] Zhang CY, Jiang XB, Rong MZ, Zhang MQ. Free radical polymerization aided selfhealing. J Intell Mater Syst Struct 2014;25:31-9.

[207] Hillewaere XK, Teixeira RF, Nguyen LTT, Ramos JA, Rahier H, Du Prez FE. Autonomous Self-Healing of Epoxy Thermosets with Thiol-Isocyanate Chemistry. Adv Funct Mater 2014;24:5575-83.

[208] Bleay S, Loader C, Hawyes V, Humberstone L, Curtis P. A smart repair system for polymer matrix composites. Composites A 2001;32:1767-76.

[209] Pang J, Bond I. 'Bleeding composites'_-damage detection and self-repair using a biomimetic approach. Composites A 2005;36:183-8.

[210] Pang JW, Bond IP. A hollow fibre reinforced polymer composite encompassing selfhealing and enhanced damage visibility. Compos Sci Technol 2005;65:1791-9.

[211] Trask R, Bond I. Biomimetic self-healing of advanced composite structures using hollow glass fibres. Smart Mater Struct 2006;15:704-10.

[212] Trask R, Williams G, Bond I. Bioinspired self-healing of advanced composite structures using hollow glass fibres. J R Soc Interface 2007;4:363-71. 
[213] Williams G, Trask R, Bond I. A self-healing carbon fibre reinforced polymer for aerospace applications. Composites A 2007;38:1525-32.

[214] Williams G, Bond I, Trask R. Compression after impact assessment of self-healing CFRP. Composites A 2009;40:1399-406.

[215] Zainuddin S, Arefin T, Fahim A, Hosur M, Tyson J, Kumar A, Trovillion J, Jeelani S. Recovery and improvement in low-velocity impact properties of e-glass/epoxy composites through novel self-healing technique. Compos Struct 2014;108:277-86.

[216] Kling S, Czigány T. Damage detection and self-repair in hollow glass fiber fabricreinforced epoxy composites via fiber filling. Compos Sci Technol 2014;99:82-8.

[217] Toohey KS, Sottos NR, Lewis JA, Moore JS, White SR. Self-healing materials with microvascular networks. Nat Mater 2007;6:581-5.

[218] Toohey KS, Hansen CJ, Lewis JA, White SR, Sottos NR. Delivery of Two-Part SelfHealing Chemistry via Microvascular Networks. Adv Funct Mater 2009;19:1399-405.

[219] Toohey K, Sottos N, White S. Characterization of microvascular-based self-healing coatings. Exp Mech 2009;49:707-17.

[220] Hansen CJ, Wu W, Toohey KS, Sottos NR, White SR, Lewis JA. Self-Healing Materials with Interpenetrating Microvascular Networks. Adv Mater 2009;21:4143-7.

[221] Patrick JF, Hart KR, Krull BP, Diesendruck CE, Moore JS, White SR, Sottos NR. Continuous Self-Healing Life Cycle in Vascularized Structural Composites. Adv Mater 2014;26:4302-8.

[222] White S, Moore J, Sottos N, Krull B, Santa Cruz W, Gergely R. Restoration of Large Damage Volumes in Polymers. Science 2014;344:620-3.

[223] Zhao Z, Arruda EM. An Internal Cure for Damaged Polymers. Science 2014;344:591-2.

[224] Hamilton AR, Sottos NR, White SR. Self-Healing of Internal Damage in Synthetic Vascular Materials. Adv Mater 2010;22:5159-63.

[225] Williams H, Trask R, Bond I. Self-healing composite sandwich structures. Smart Mater Struct 2007; 16:1198.

[226] Williams H, Trask R, Bond I. Self-healing sandwich panels: restoration of compressive strength after impact. Compos Sci Technol 2008;68:3171-7.

[227] Norris C, Bond I, Trask R. The role of embedded bioinspired vasculature on damage formation in self-healing carbon fibre reinforced composites. Composites A 2011;42:63948. 
[228] Norris C, Bond I, Trask R. Interactions between propagating cracks and bioinspired selfhealing vascules embedded in glass fibre reinforced composites. Compos Sci Technol 2011;71:847-53.

[229] Chen C, Peters K, Li Y. Self-healing sandwich structures incorporating an interfacial layer with vascular network. Smart Mater Struct 2013;22:025031/1-15.

[230] Coppola AM, Thakre PR, Sottos NR, White SR. Tensile properties and damage evolution in vascular 3D woven glass/epoxy composites. Composites A 2014;59:9-17.

[231] Norris CJ, Meadway GJ, O'Sullivan MJ, Bond IP, Trask RS. Self-Healing Fibre Reinforced Composites via a Bioinspired Vasculature. Adv Funct Mater 2011;21:362433.

[232] Carlson J, English J, Coe D. A flexible, self-healing sensor skin. Smart Mater Struct 2006;15:129-35.

[233] Liu HA, Gnade BE, Balkus KJ. A Delivery System for Self-Healing Inorganic Films. Adv Funct Mater 2008;18:3620-9.

[234] Hayes S, Zhang W, Branthwaite M, Jones F. Self-healing of damage in fibre-reinforced polymer-matrix composites. J R Soc Interface 2007;4:381-7.

[235] Hayes S, Jones F, Marshiya K, Zhang W. A self-healing thermosetting composite material. Composites A 2007;38:1116-20.

[236] Pingkarawat K, Wang C, Varley R, Mouritz A. Self-healing of delamination cracks in mendable epoxy matrix laminates using poly [ethylene- $<\mathrm{i}>\operatorname{co}</ \mathrm{i}>$-(methacrylic acid)] thermoplastic. Composites A 2012;43:1301-7.

[237] Pingkarawat K, Wang C, Varley R, Mouritz A. Mechanical properties of mendable composites containing self-healing thermoplastic agents. Composites A 2014;65:10-18.

[238] Huang L, Yi N, Wu Y, Zhang Y, Zhang Q, Huang Y, Ma Y, Chen Y. Multichannel and Repeatable Self-Healing of Mechanical Enhanced Graphene-Thermoplastic Polyurethane Composites. Adv Mater 2013;25:2224-8.

[239] Asadi J, Ebrahimi NG, Razzaghi-Kashani M. Self-healing property of epoxy/nanoclay nanocomposite using poly (ethylene-co-methacrylic acid) agent. Composites A 2015;68:56-61.

[240] Heo Y, Sodano HA. Self-Healing Polyurethanes with Shape Recovery. Adv Funct Mater 2014;24:5261-8. 
[241] Zhang W, Duchet J, Gérard J. Self-Healable Interfaces Based on thermo-reversible DielsAlder Reactions in Carbon Fiber Reinforced Composites. J Colloid Interface Sci 2014;460:61-8.

[242] Li G, Nettles D. Thermomechanical characterization of a shape memory polymer based self-repairing syntactic foam. Polymer 2010;51:755-62.

[243] Nji J, Li G. A biomimic shape memory polymer based self-healing particulate composite. Polymer 2010;51:6021-9.

[244] Li G, Uppu N. Shape memory polymer based self-healing syntactic foam: 3-D confined thermomechanical characterization. Compos Sci Technol 2010;70:1419-27.

[245] Nosonovsky M, Bhushan B. Surface self-organization: from wear to self-healing in biological and technical surfaces. Appl Surf Sci 2010;256:3982-7.

[246] Park JH, Braun PV. Coaxial Electrospinning of Self-Healing Coatings. Adv Mater 2010;22:496-9.

[247] Williams H, Trask R, Knights A, Williams E, Bond I. Biomimetic reliability strategies for self-healing vascular networks in engineering materials. J R Soc Interface 2008;5:735-47.

[248] Trask R, Bond I. Bioinspired engineering study of Plantae vascules for self-healing composite structures. J R Soc Interface 2010;7:921-31.

[249] Andreeva DV, Fix D, Shchukin DG. Self-Healing Anticorrosion Coatings Based on pHSensitive Polyelectrolyte/Inhibitor Sandwichlike Nanostructures. Adv Mater 2008;20:2789-94.

[250] Dou Y, Zhou A, Pan T, Han J, Wei M, Evans DG, Duan X. Humidity-triggered selfhealing films with excellent oxygen barrier performance. Chem Commun 2014;50:71368.

[251] Zhu Y, Yao C, Ren J, Liu C, Ge L. Graphene improved electrochemical property in selfhealing multilayer polyelectrolyte film. Colloids Surf A 2014;465:26-31.

[252] Ensslin S, Moll KP, Haefele-Racin T, Mäder K. Safety and robustness of coated pellets: self-healing film properties and storage stability. Pharm Res 2009;26:1534-43.

[253] Selver E, Potluri P, Soutis C, Hogg P. Healing potential of hybrid materials for structural composites. Compos Struct 2014;122:57-66.

[254] Park JS, Kim HS, Hahn HT. Healing behavior of a matrix crack on a carbon fiber/mendomer composite. Compos Sci Technol 2009;69:1082-7. 
[255] Kavitha AA, Singha NK. "Click chemistry" in tailor-made polymethacrylates bearing reactive furfuryl functionality: a new class of self-healing polymeric material. ACS Appl Mater Interfaces 2009;1:1427-36.

[256] Park JS, Darlington T, Starr AF, Takahashi K, Riendeau J, Hahn HT. Multiple healing effect of thermally activated self-healing composites based on Diels-Alder reaction. Compos Sci Technol 2010;70:2154-9.

[257] Lee JY, Buxton GA, Balazs AC. Using nanoparticles to create self-healing composites. J Chem Phy 2004;121:5531-40.

[258] Burattini S, Colquhoun HM, Greenland BW, Hayes W. A novel self-healing supramolecular polymer system. Faraday Discuss 2009;143:251-64.

[259] Hu J, Meng H, Li G, Ibekwe SI. A review of stimuli-responsive polymers for smart textile applications. Smart Mater Struct 2012;21:053001/1-23.

[260] Yougoubare YQ, Pang SS. Effects of programming and healing temperatures on the healing efficiency of a confined healable polymer composite. Smart Mater Struct 2014;23:025027/1-9.

[261] Rodriguez ED, Luo X, Mather PT. Linear/network poly ( $\varepsilon$-caprolactone) blends exhibiting shape memory assisted self-healing (SMASH). ACS Appl Mater Interfaces 2011;3:152-61.

[262] Luo X, Mather PT. Shape memory assisted self-healing coating. ACS Macro Lett 2013;2:152-6.

[263] Li G, John M. A self-healing smart syntactic foam under multiple impacts. Compos Sci Technol 2008;68:3337-43.

[264] Wang X, Zhao J, Chen M, Ma L, Zhao X, Dang ZM, Wang Z. Improved Self-Healing of Polyethylene/Carbon Black Nanocomposites by Their Shape Memory Effect. J Phys Chem B 2013;117:1467-74.

[265] Nji J, Li G. A self-healing 3D woven fabric reinforced shape memory polymer composite for impact mitigation. Smart Mater Struct 2010;19:035007/1-9.

[266] John M, Li G. Self-healing of sandwich structures with a grid stiffened shape memory polymer syntactic foam core. Smart Mater Struct 2010;19:075013/1-12.

[267] Li G, Ajisafe O, Meng H. Effect of strain hardening of shape memory polymer fibers on healing efficiency of thermosetting polymer composites. Polymer 2013;54:920-8. 
[268] Li G, Xu W. Thermomechanical behavior of thermoset shape memory polymer programmed by cold-compression: testing and constitutive modeling. J Mech Phys Solids 2011;59:1231-50.

[269] Xu W, Li G. Constitutive modeling of shape memory polymer based self-healing syntactic foam. Int J Solids Struct 2010;47:1306-16.

[270] Xu W, Li G. Thermoviscoplastic modeling and testing of shape memory polymer based self-healing syntactic foam programmed at glassy temperature. J Appl Mech 2011;78:061017/1-14.

[271] Li G, Nji J. Thermosetting Shape Memory Polymers with Ability to Perform Repeated Molecular Scale Healing. US20120303056 A1, 2012.

[272] Xiao X, Xie T, Cheng YT. Self-healable graphene polymer composites. J Mater Chem 2010;20:3508-14.

[273] Xiao X, Xie T, Cheng YT. Self-healing and scratch resistant shape memory polymer system. US8198349 B2; GL Global Technology Operations LLC, 2012,.

[274] Wang C, Ding Z, Purnawali H, Huang W, Fan H, Sun L. Repeated instant self-healing shape memory composites. J Mater Eng Perform 2012;21:2663-9.

[275] Wang C, Huang W, Ding Z, Zhao Y, Purnawali H, Zheng LX, Fan H, He CB. Rubberlike shape memory polymeric materials with repeatable thermal-assisted healing function. Smart Mater Struct 2012;21:115010/1-8.

[276] Wu X, Huang W, Seow Z, Chin W, Yang W, Sun K. Two-step shape recovery in heatingresponsive shape memory polytetrafluoroethylene and its thermally assisted self-healing. Smart Mater Struct 2013;22:125023/1-12.

[277] Huang W, Ding Z, Wang C, Wei J, Zhao Y, Purnawali H. Shape memory materials. Mater Today 2010;13:54-61.

[278] Xu T, Li G. Cyclic stress-strain behavior of shape memory polymer based syntactic foam programmed by 2-D stress condition. Polymer 2011;52:4571-80.

[279] Xu T, Li G. A shape memory polymer based syntactic foam with negative Poisson's ratio. Mater Sci Eng A 2011;528:6804-11.

[280] Xu T, Li G, Pang SS. Effects of ultraviolet radiation on morphology and thermomechanical properties of shape memory polymer based syntactic foam. Composites A 2011;42:1525-33.

[281] Xu T, Li G. Durability of shape memory polymer based syntactic foam under accelerated hydrolytic ageing. Mater Sci Eng A 2011;528:7444-50. 
[282] Li G, Xu T. Thermomechanical Characterization of Shape Memory Polymer-Based SelfHealing Syntactic Foam Sealant for Expansion Joints. J Transp Eng 2011;137:805-14.

[283] Li G, Ji G, Meng H. Shape Memory Polymer-Based Sealant for a Compression Sealed Joint. J Mater Civ Eng 2014;27:04014196/1-7.

[284] Li G, King A, Xu T, Huang X. Behavior of Thermoset Shape Memory Polymer-Based Syntactic Foam Sealant Trained by Hybrid Two-Stage Programming. J Mater Civ Eng 2012;25:393-402.

[285] Nishikawa M, Wakatsuki K, Yoshimura A, Takeda N. Effect of fiber arrangement on shape fixity and shape recovery in thermally activated shape memory polymer-based composites. Composites A 2012;43:165-73.

[286] Li G, Ji G, Zhenyu O. Adhesively bonded healable composite joint. Int J Adhes Adhes 2012;35:59-67.

[287] Sun S, Sun G, Han F, Wu J. Thermoviscoelastic analysis for a polymeric composite plate with embedded shape memory alloy wires. Compos Struct 2002;58:295-302.

[288] Song G, Ma N, Li HN. Applications of shape memory alloys in civil structures. Eng Struct 2006;28:1266-74.

[289] Burton D, Gao X, Brinson L. Finite element simulation of a self-healing shape memory alloy composite. Mech Mater 2006;38:525-37.

[290] Zhang RX, Ni QQ, Natsuki T, Iwamoto M. Mechanical properties of composites filled with SMA particles and short fibers. Compos Struct 2007;79:90-6.

[291] Ni QQ, Zhang RX, Natsuki T, Iwamoto M. Stiffness and vibration characteristics of SMA/ER3 composites with shape memory alloy short fibers. Compos Struct 2007;79:501-7.

[292] Kirkby EL, Rule JD, Michaud VJ, Sottos NR, White SR, Månson JAE. Embedded Shape-Memory Alloy Wires for Improved Performance of Self-Healing Polymers. Adv Funct Mater 2008;18:2253-60.

[293] Kirkby E, Michaud V, Månson JA, Sottos N, White S. Performance of self-healing epoxy with microencapsulated healing agent and shape memory alloy wires. Polymer 2009;50:5533-8.

[294] Wang Y, Zhou L, Wang Z, Huang H, Ye L. Stress distributions in single shape memory alloy fiber composites. Mater Des 2011;32:3783-9.

[295] Wang Y, Zhou L, Wang Z, Huang H, Ye L. Analysis of internal stresses induced by strain recovery in a single SMA fiber-matrix composite. Composites B 2011;42:1135-43. 
[296] Lei H, Wang Z, Zhou B, Tong L, Wang X. Simulation and analysis of shape memory alloy fiber reinforced composite based on cohesive zone model. Mater Des 2012;40:13847.

[297] Neuser S, Michaud V, White S. Improving solvent-based self-healing materials through shape memory alloys. Polymer 2012;53:370-8.

[298] Li G, Shojaei A. A viscoplastic theory of shape memory polymer fibres with application to self-healing materials. P Roy Soc A $\backslash 2012 ; 468: 2319-46$.

[299] Li G, Meng H, Hu J. Healable thermoset polymer composite embedded with stimuliresponsive fibres. J R Soc Interface 2012;9:3279-87.

[300] Yang Q, Li G. Investigation into stress recovery behavior of shape memory polyurethane fiber. J Polym Sci Part B Polym Phys 2014;52:1429-40.

[301] Zhang P, Li G. Structural relaxation behavior of strain hardened shape memory polymer fibers for self-healing applications. J Polym Sci Part B Polym Phys 2013;51:966-77.

[302] Li G, Zhang P. A self-healing particulate composite reinforced with strain hardened short shape memory polymer fibers. Polymer 2013;54:5075-86.

[303] Lima MD, Li N, De Andrade MJ, Fang S, Oh J, Spinks GM, Kozlov1 ME., Haines CS, Suh D, Foroughi J, Kim SJ, Chen Y, Ware T, Shin MK, Machado LD, Fonseca AF, Madden JD, Voit WE, Galvão DS, Baughman RH. Electrically, chemically, and photonically powered torsional and tensile actuation of hybrid carbon nanotube yarn muscles. Science 2012;338:928-32.

[304] Haines CS, Lima MD, Li N, Spinks GM, Foroughi J, Madden JD, Kim SH, Fang S, de Andrade MJ, Göktepe F, Göktepe Ö, Mirvakili SM, Naficy S, Lepró X, Oh J, Kozlov ME, Kim SJ, Xu X, Swedlove BJ, Wallace GG, Baughman RH. Artificial muscles from fishing line and sewing thread. Science 2014;343:868-72.

[305] Lima MD, Hussain MW, Spinks GM, Naficy S, Hagenasr D, Bykova JS, Tolly D, Baughman RH. Efficient, Absorption-Powered Artificial Muscles Based on Carbon Nanotube Hybrid Yarns. Small 2015;11:3113-8.

[306] Sharafi S, Li G. A multiscale approach for modeling actuation response of polymeric artificial muscles. Soft matter 2015;11:3833-43.

[307] Zhang P, Li G. Healing-on-demand composites based on polymer artificial muscle. Polymer 2015;64:29-38.

[308] Lemaitre J, Dufailly J. Damage measurements. Eng Fract Mech 1987;28:643-61. 
[309] Lubarda V, Krajcinovic D. Damage tensors and the crack density distribution. Int J Solids Struct 1993;30:2859-77.

[310] Voyiadjis GZ, Kattan P. A comparative study of damage variables in continuum damage mechanics. Int J Damage Mech 2009;18:315-40.

[311] Voyiadjis GZ, Shojaei A, Li G, Kattan PI. A theory of anisotropic healing and damage mechanics of materials. P Roy Soc A $2012 ; 468: 163-83$.

[312] Voyiadjis GZ, Shojaei A, Li G. A thermodynamic consistent damage and healing model for self healing materials. Int J Plast 2011;27:1025-44.

[313] Voyiadjis GZ, Shojaei A, Li G. A generalized coupled viscoplastic-viscodamageviscohealing theory for glassy polymers. Int J Plast 2012;28:21-45.

[314] Shojaei A, Li G. Thermomechanical constitutive modelling of shape memory polymer including continuum functional and mechanical damage effects. P Roy Soc A\ 2014;470:20140199.

[315] Shojaei A, Sharafi S, Li G. A Multiscale Theory of Self-Crack-Healing with Solid Healing Agent Assisted by Shape Memory Effect. Mech Mater 2015;81:25-40.

[316] Kim YH, Wool RP. A theory of healing at a polymer-polymer interface. Macromolecules $1983 ; 16: 1115-20$.

[317] White KL, Wong M, Miyamoto M, Higaki Y, Takahara A, Sue HJ. Interlayer structure and self-healing in suspensions of brush-stabilized nanoplatelets in smectic order. Soft Matter 2014 doi: 10.1039/C4SM01855A.

[318] de Gennes PG. Reptation of a polymer chain in the presence of fixed obstacles. J Chem Phys 1971;55:572-9.

[319] Klein J. The onset of entangled behavior in semidilute and concentrated polymer solutions. Macromolecules 1978;11:852-8.

[320] Klein J. Evidence for reptation in an entangled polymer melt. Nature 1978;271:143-5.

[321] Bousmina M, Qiu H, Grmela M, Klemberg-Sapieha J. Diffusion at polymer/polymer interfaces probed by rheological tools. Macromolecules 1998;31:8273-80.

[322] Ji G, Ouyang Z, Li G. Effects of bondline thickness on Mode-I nonlinear interfacial fracture of laminated composites: an experimental study. Composites B 2013;47:1-7.

[323] Ji G, Ouyang Z, Li G. Local interface shear fracture of bonded steel joints with various bondline thicknesses. Exp Mech 2012;52:481-91. 
[324] Ouyang Z, Ji G, Li G. On approximately realizing and characterizing pure Mode-I interface fracture between bonded dissimilar materials. J Appl Mech 2011;78:031020/111.

[325] Ji G, Ouyang Z, Li G. Effects of bondline thickness on Mode-II interfacial laws of bonded laminated composite plate. Int J Fract 2011;168:197-207.

[326] Ji G, Ouyang Z, Li G, Ibekwe S, Pang SS. Effects of adhesive thickness on global and local Mode-I interfacial fracture of bonded joints. Int J Solids Struct 2010;47:2445-58.

[327] Boettinger W, Warren J, Beckermann C, Karma A. Phase-field simulation of solidification 1. Annu Rev Mater Res 2002;32:163-94.

[328] Zhang P, Ogunmekan B, Ibekwe S, Jerro D, Pang SS, Li G. Healing of Shape Memory Polyurethane Fiber Reinforced Syntactic Foam Subjected to Tensile Stress. J Intell Mater Syst Struct 20XX;Accepted. 


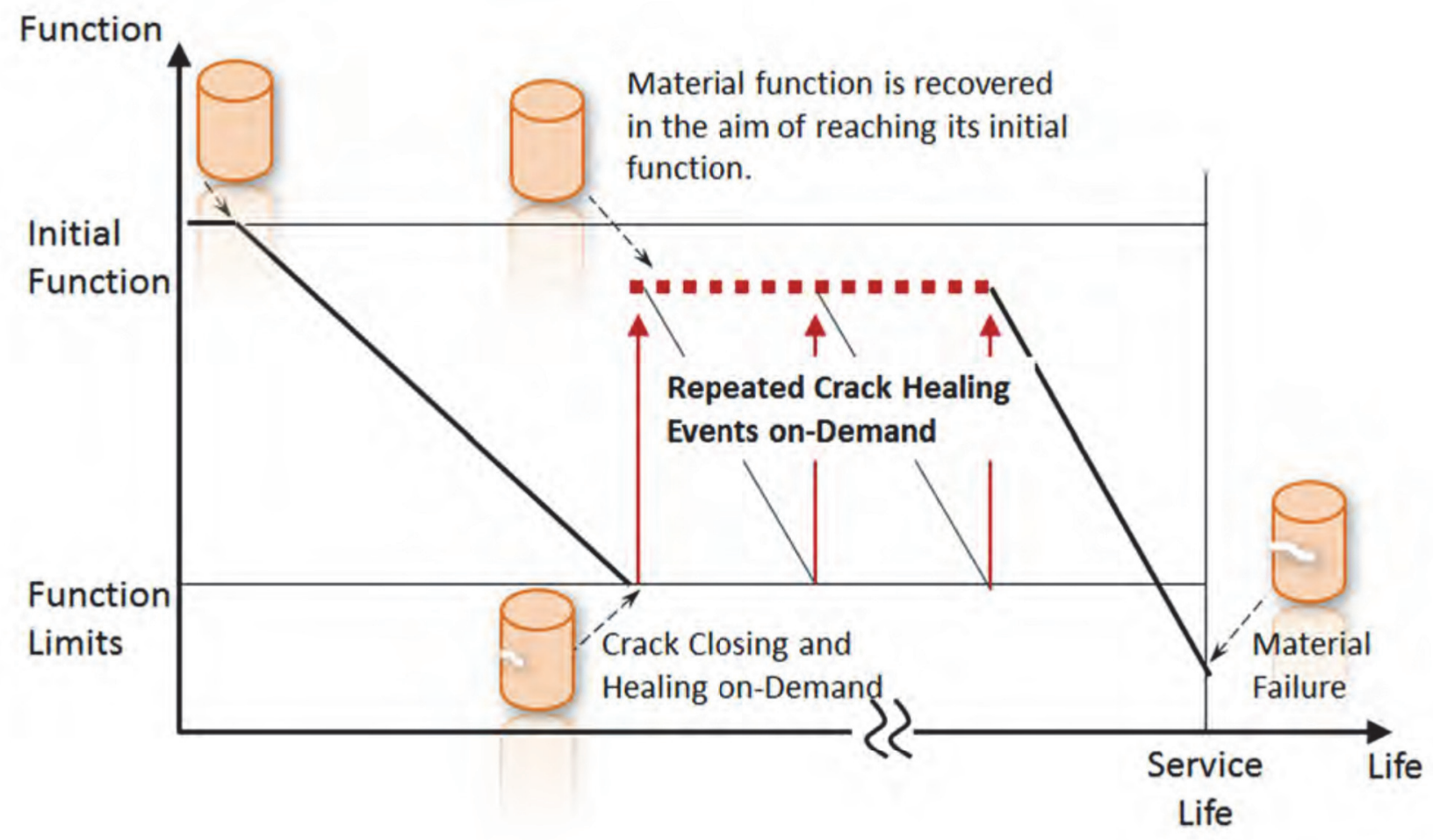

Fig 1. Conceptual healing-on-demand in prolonging material service life. As damage occurs, engineering polymers/polymer composites suffer from functional and structural degradation over service life. Crack closing and healing are triggered by the response to the lower bound (function limit) of the function, i.e., on-demand, and thus recovers its functionality to initial status repeatedly for prolonging service life. 


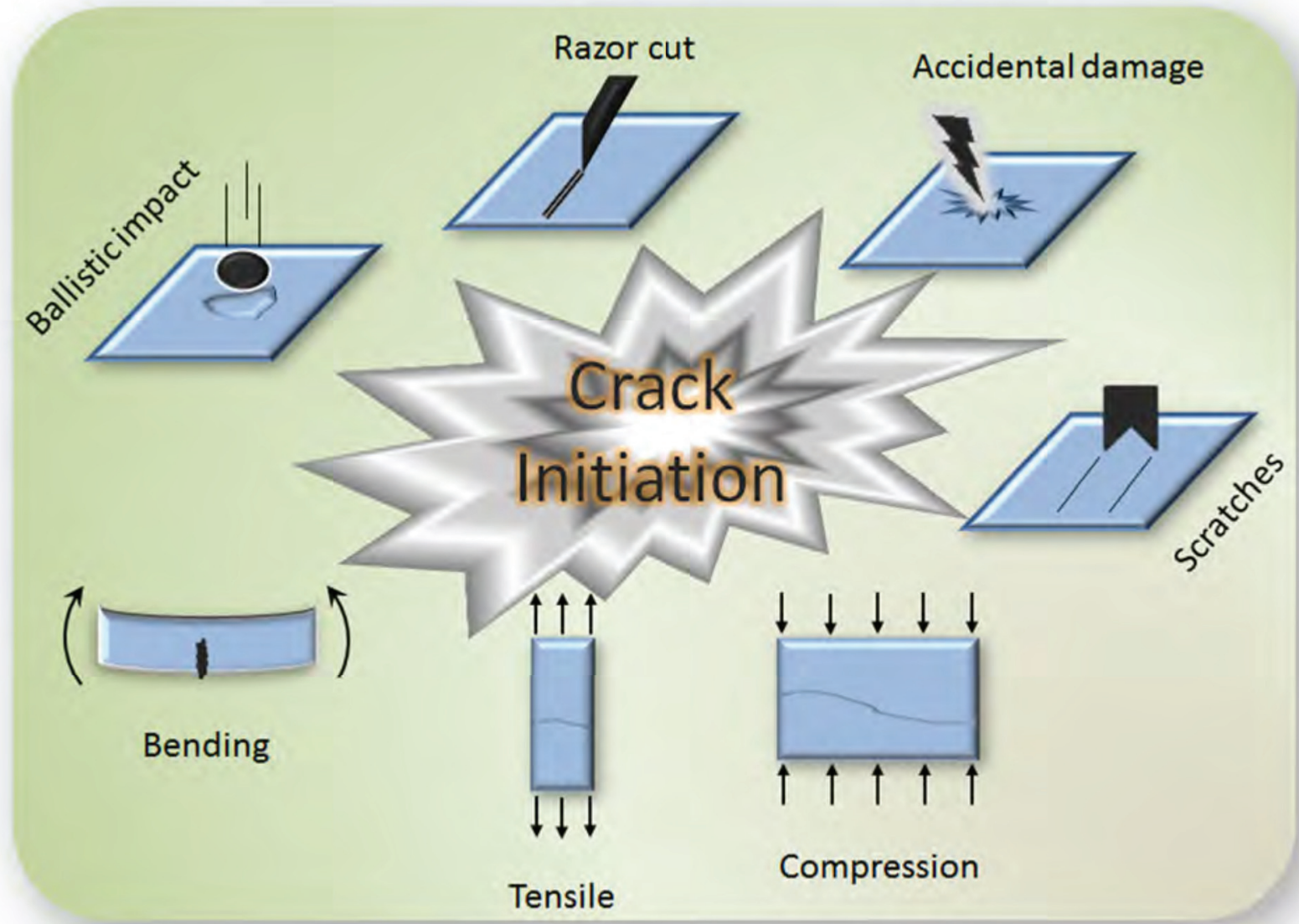

Fig 2. Types of crack modes initiated by various loadings. 


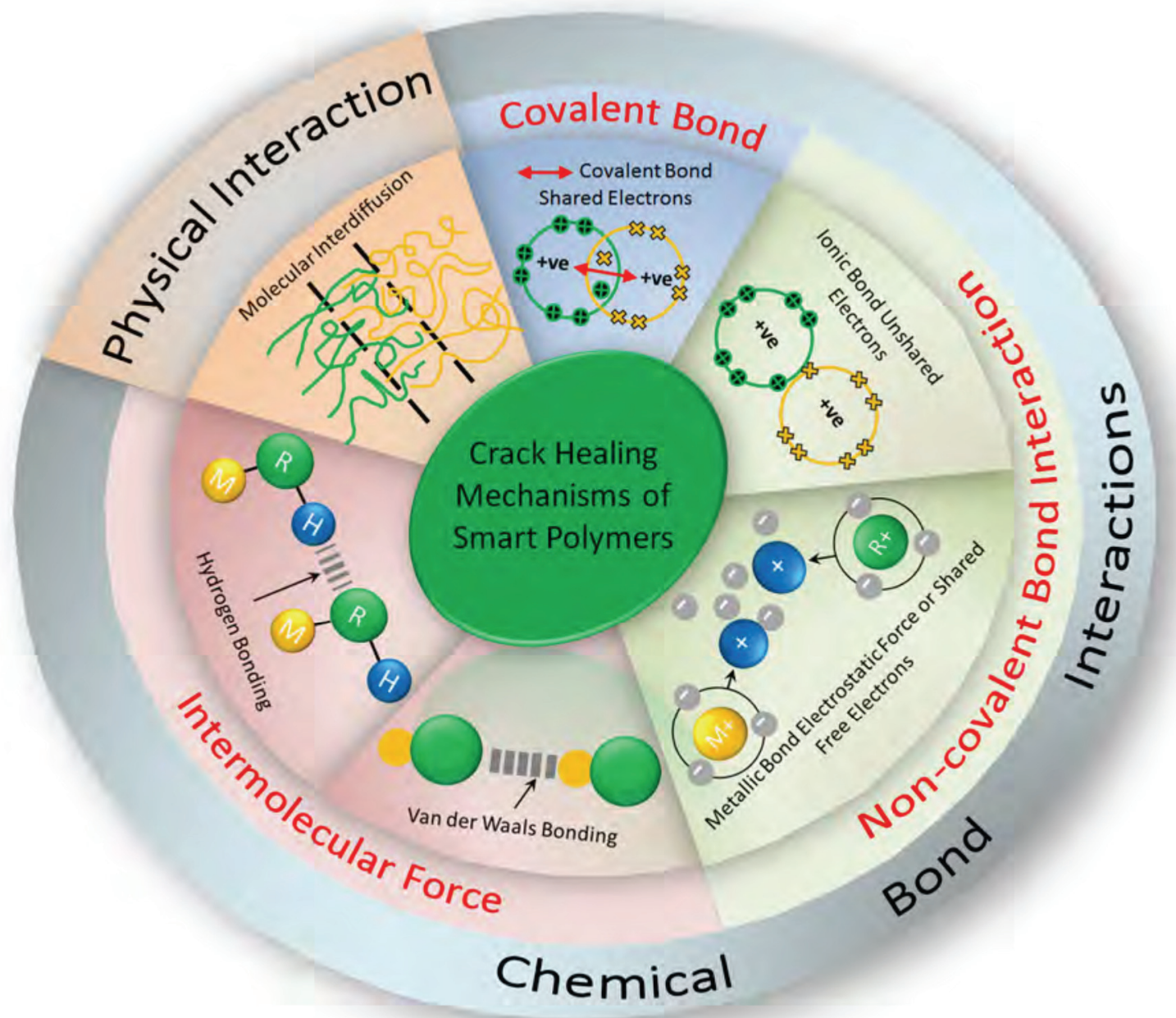

Fig 3. Types of crack healing mechanisms of smart polymers including physical interaction and chemical bond interactions. 

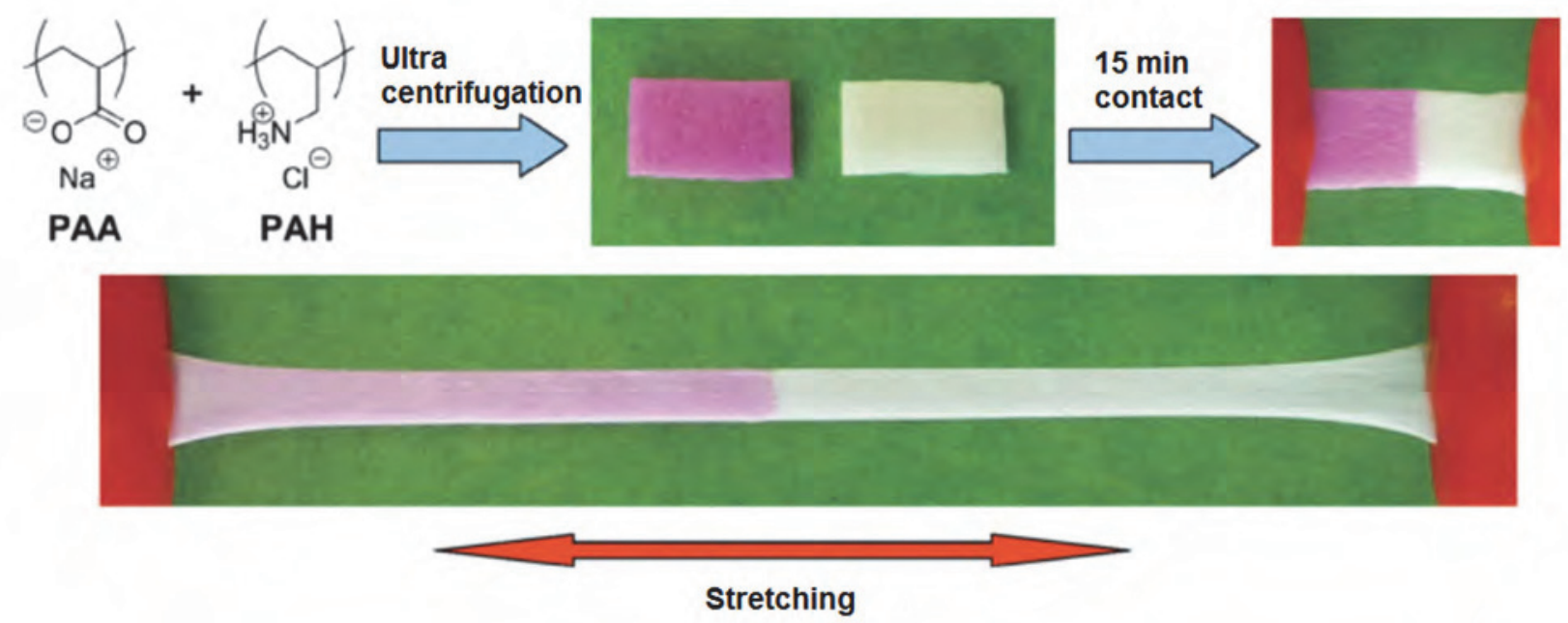

Fig 4. Procedures of preparing, cutting, healing, and stretching of the compact polyelectrolyte (all at room temperature). [65], Copyright 2014. Reproduced with permission from John Wiley \& Sons Inc. 
$\mathbf{a}$

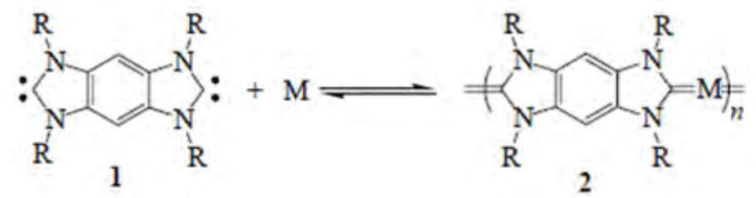

b

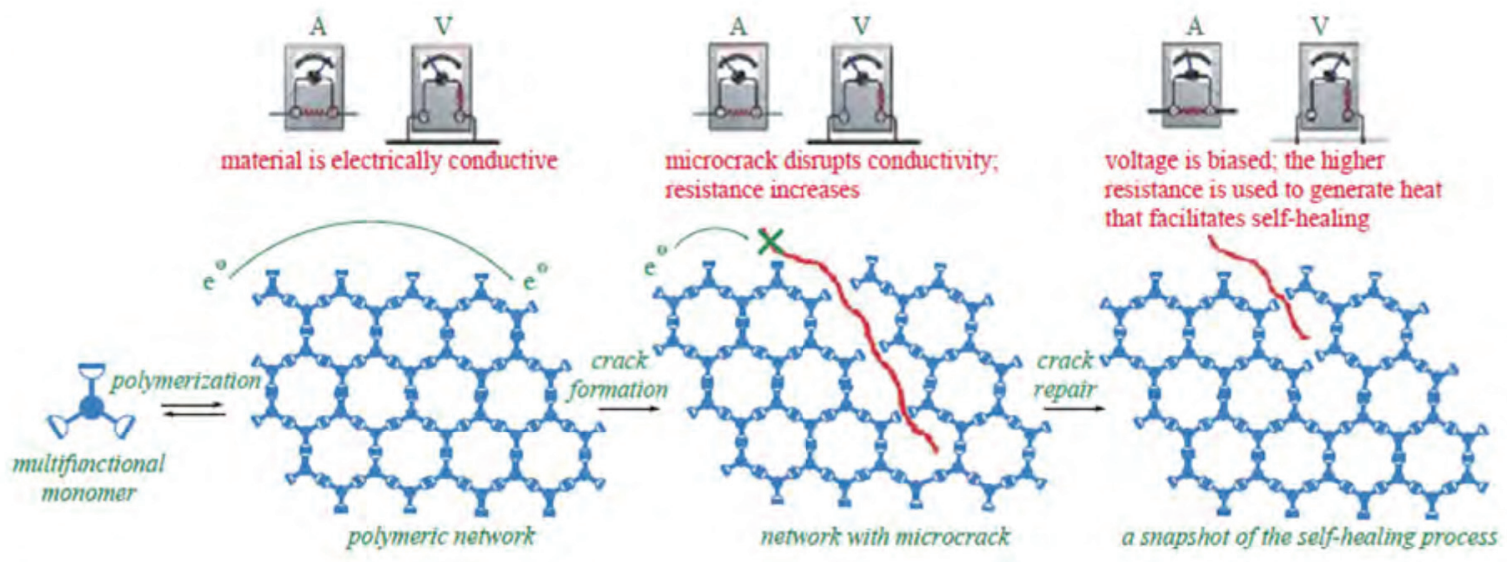

Fig 5. (a) Compounds formed between NHCs and transition metals in polymeric materials. The structurally dynamic equilibrium between a monomer species (left) and an organometallic polymer (right) is controlled via a thermal treatment. $\mathrm{M}=\mathrm{Ni}, \mathrm{Pd}$ and $\mathrm{Pt}$; $\mathrm{R}=$ alkyl, benzyl and aryl. (b) Self-healing scheme of an electrically conductive, selfhealing organometallic polymer. When used as an electrical wire or incorporated into a device, upon the formation of a microcrack, the total number of electron percolation pathways within the material should decrease, resulting in increase in inherent electrical resistance, which leads to the generation of heat localized at the microcrack due to the voltage bias. The generated thermal energy thus hurdles the kinetic energy barriers, driving the system back to its original state. A: amperes; V: volts. [66], Copyright 2007. Reproduced with permission from the Royal Society of Chemistry. 

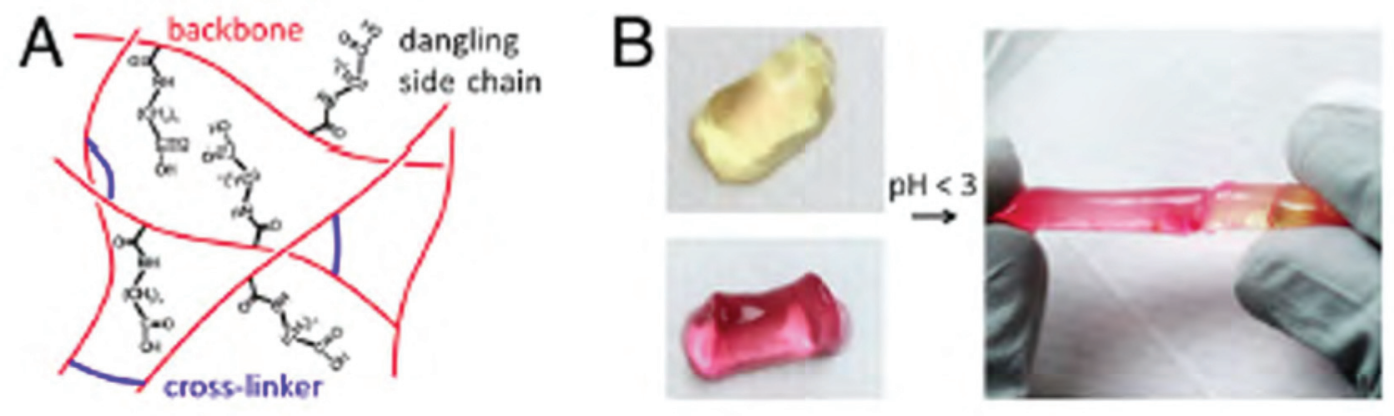

\section{C}
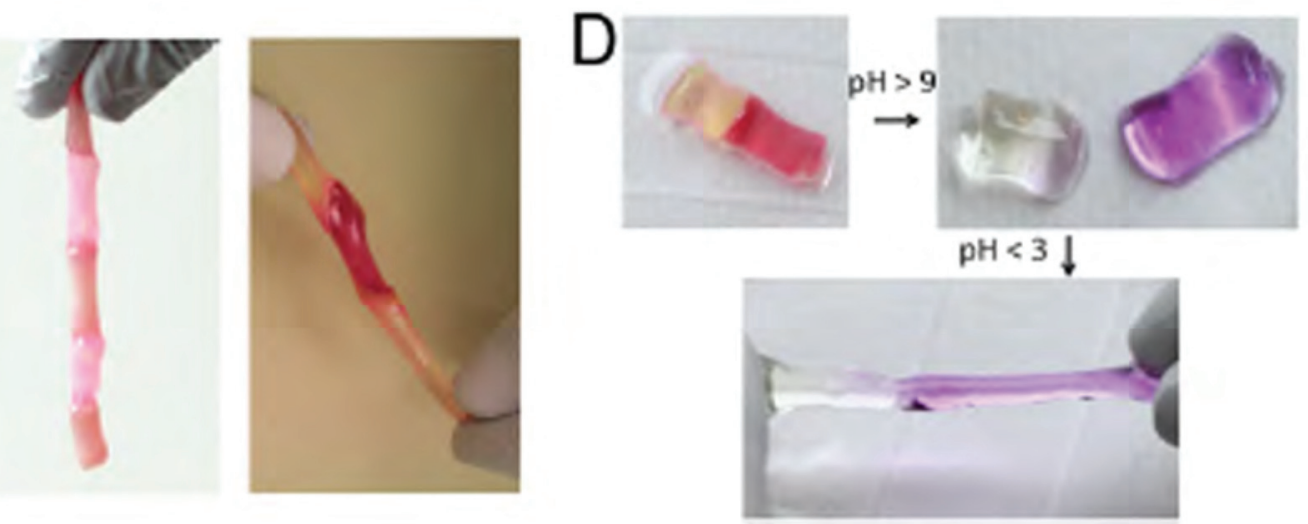

Fig 6. "Wound" healing behavior of polymeric hydrogel. At low pH (i.e., less than 3.0), molecular network was regenerated at the fracture surface due to the protonation of terminal-carboxyl groups, leading to the recovery of fracture surface. However, in the case of high $\mathrm{pH}$ (i.e., larger than 9.0), the two healed hydrogels separated due to the deprotonation of hydrogel carboxyl groups. And it rehealed again when exposed to low pH. [64], Copyright 2013. Reproduced with permission from the American Chemical Society. 


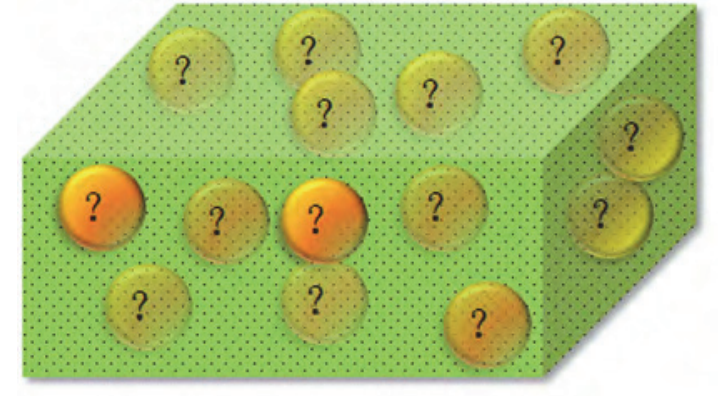

(a)

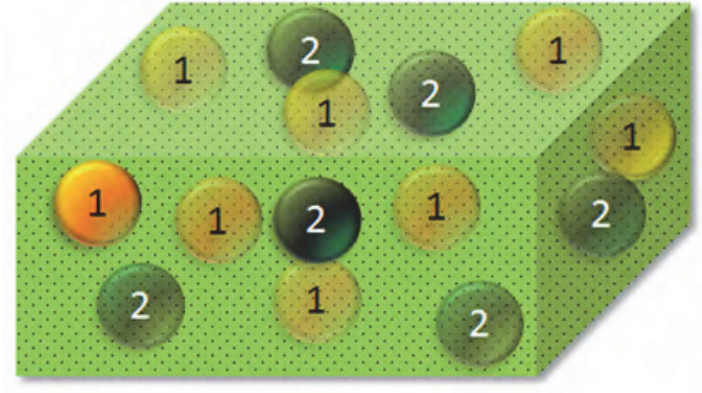

(b)

Fig 7. Microcapsulated polymer composites: (a) single-microcapsule; (b) dual microcapsule. 

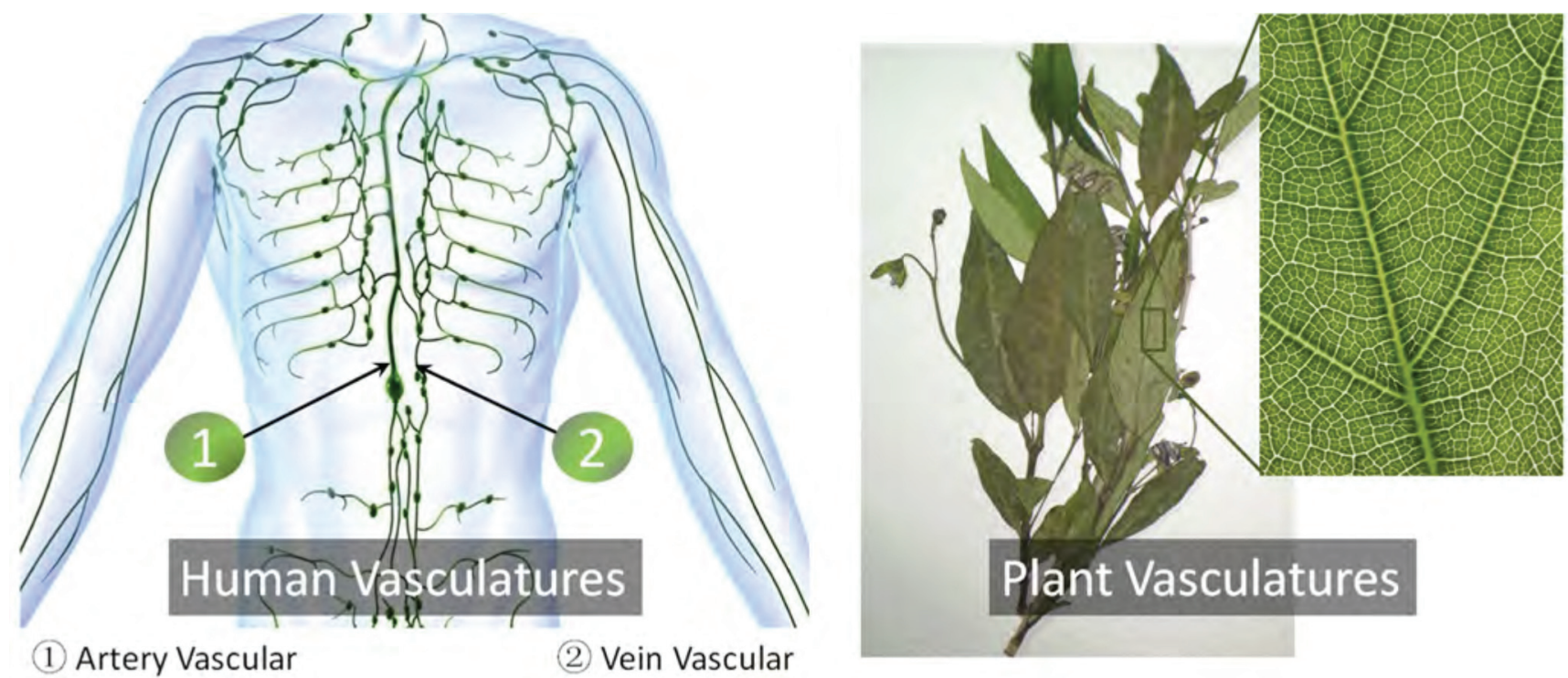

Fig 8. Branching vasculature networks in animal (e.g., human) body and plant. 

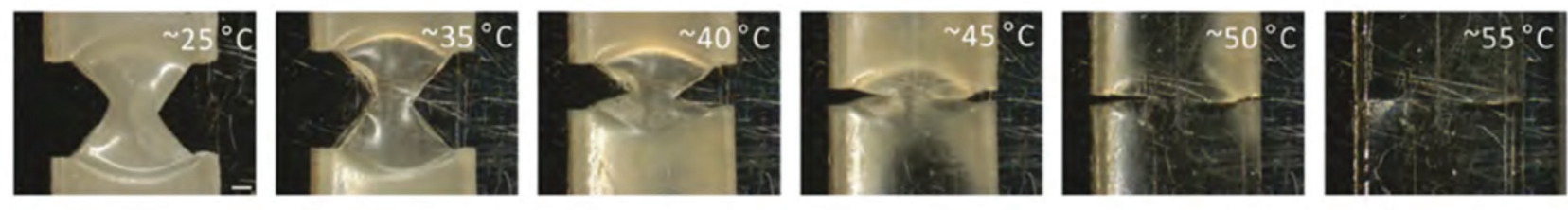

Fig 9. Crack closure due to the n-PCL shape-memory ability along with temperature and spontaneously crack rebonding due to the melt and molecular diffusion of linear 1-PCL

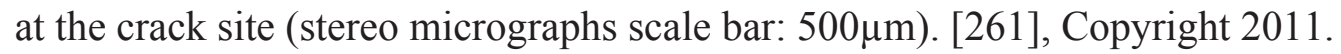
Reproduced with permission from the American Chemical Society. 


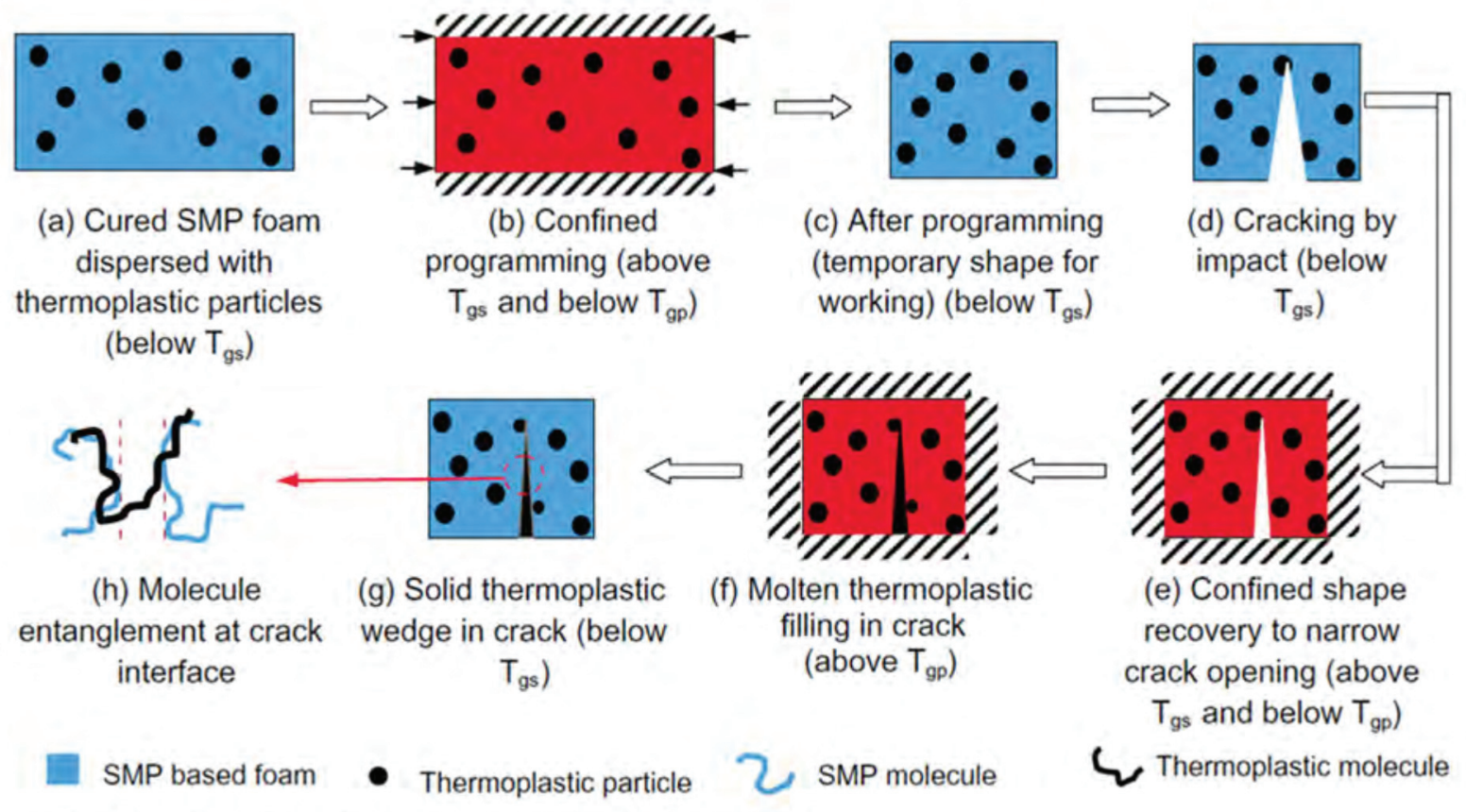

$T_{g s}$ : Glass transition temperature of the SMP based foam;

$T_{g p}$ : Glass transition temperature for amorphous thermoplastic particle or melting temperature for semi-crystalline thermoplastic particle.

Fig 10. Schematic of the close then heal (CTH) scheme of the proposed smart foam.

Compression programming process is required and necessary to enable the smart foam to have shape memory ability. Crack is narrowed or closed at a temperature above the $\mathrm{T}_{\mathrm{gs}}$ of the SMP based foam by the shape recovery of the foam, which is confined by surrounding materials. Narrowed crack is filled in by molten thermoplastic at a temperature above the $\mathrm{T}_{\mathrm{gp}}$ of the thermoplastic particle. Fracture surface would be bonded together after cooling down. Programming process: from (a) to (c); damage and crack narrowing process: (d) and (e); crack healing process: from (f) to (h). Here the $\mathrm{T}_{\mathrm{gp}}$ of thermoplastic particle must be higher than the $\mathrm{T}_{\mathrm{gs}}$ of SMP based foam. [244], Copyright 2010. Reproduced with permission from Elsevier. 


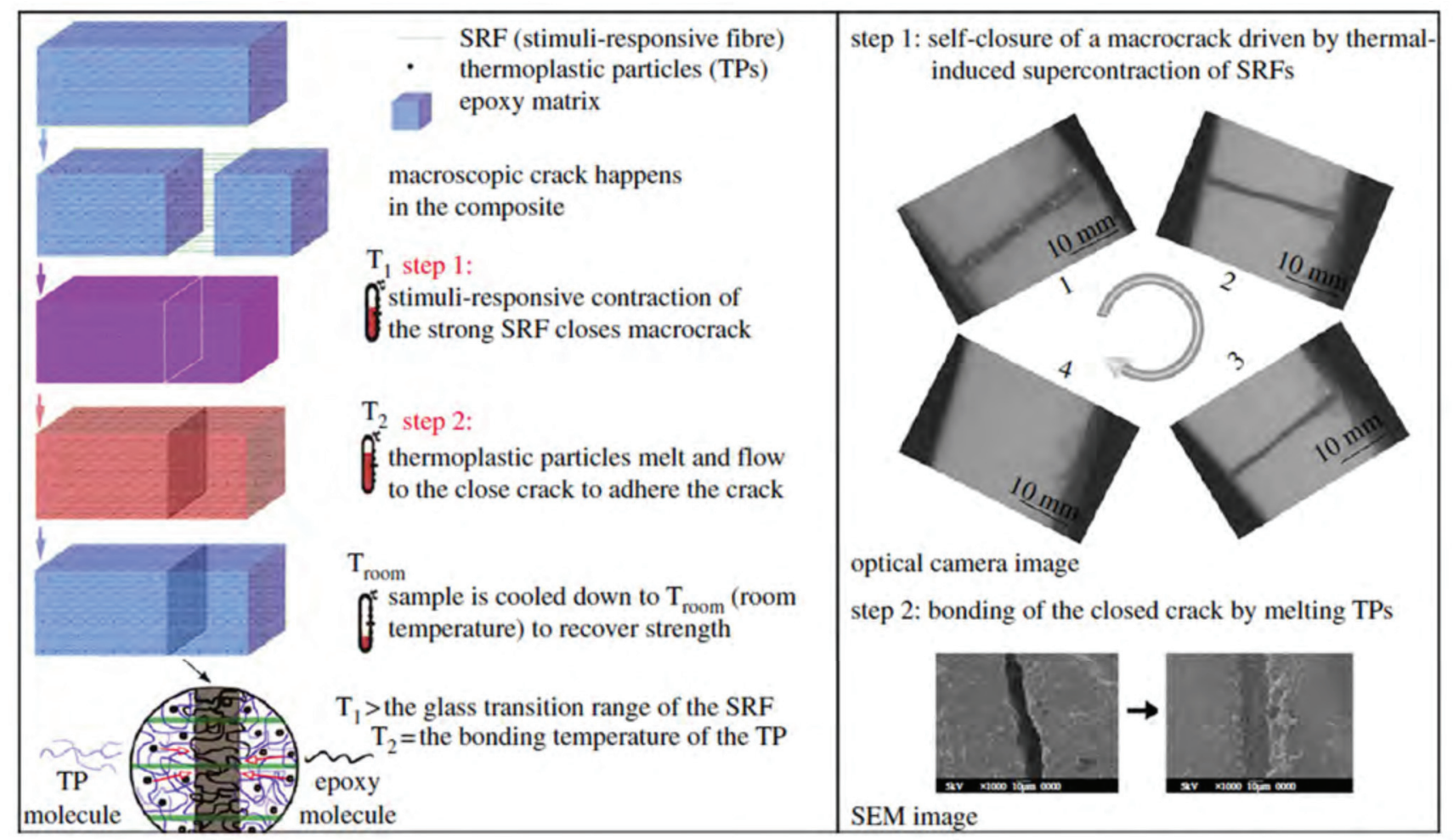

Fig 11. Two-step healing-on-demand composite by continuous shape memory polyurethane fibers. After the macroscopic crack was created in the composite, the macrocrack was closed firstly by the stimuli-responsive contraction of SMPU fibers, followed by the second step when the thermoplastic particles melt and flow into the narrowed crack to bond the crack. When the composite specimen was cooled down to room temperature (below $\mathrm{T}_{\mathrm{g}}$ ), its service strength was recovered. [299], Copyright 2012. Reproduced with permission from the Royal Society of Chemistry. 


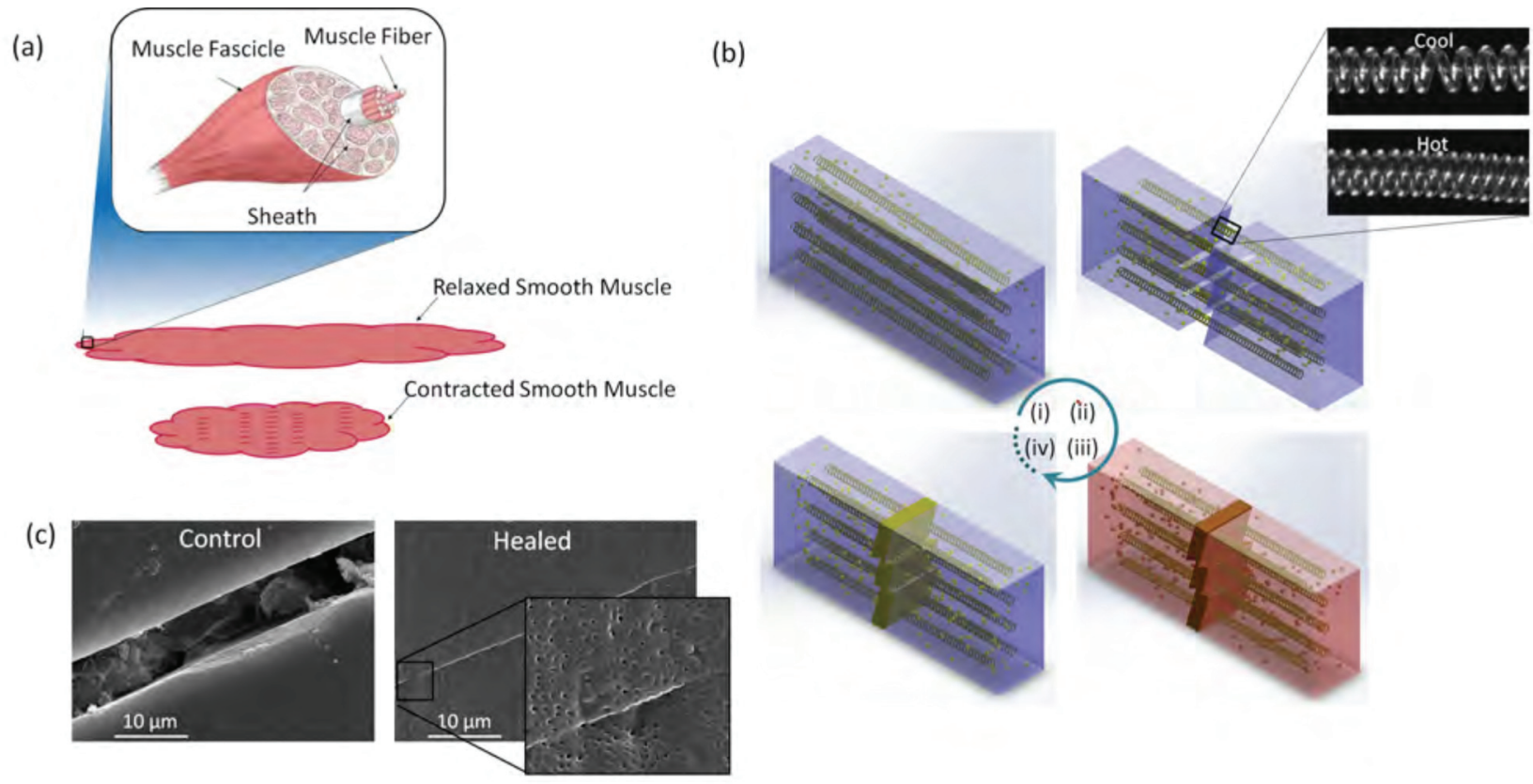

Fig 12. (a) Structure of nature muscle. (b) Schematic of on-demand healing process: (i) a polymer composite sample reinforced by polymer artificial muscle (light golden coiled fiber) and thermoplastic particle (light golden spheres) in a matrix (blue); (ii) crack initiated by external load during service life; (iii) crack closed by thermally activated artificial muscle and healed by the healing agent; (iv) solid wedge formed after cooled down, establishing continuity between the healing agent and the matrix. (c) Crack before closing and after healed. [307], Copyright 2015. Reproduced with permission from Elsevier. 


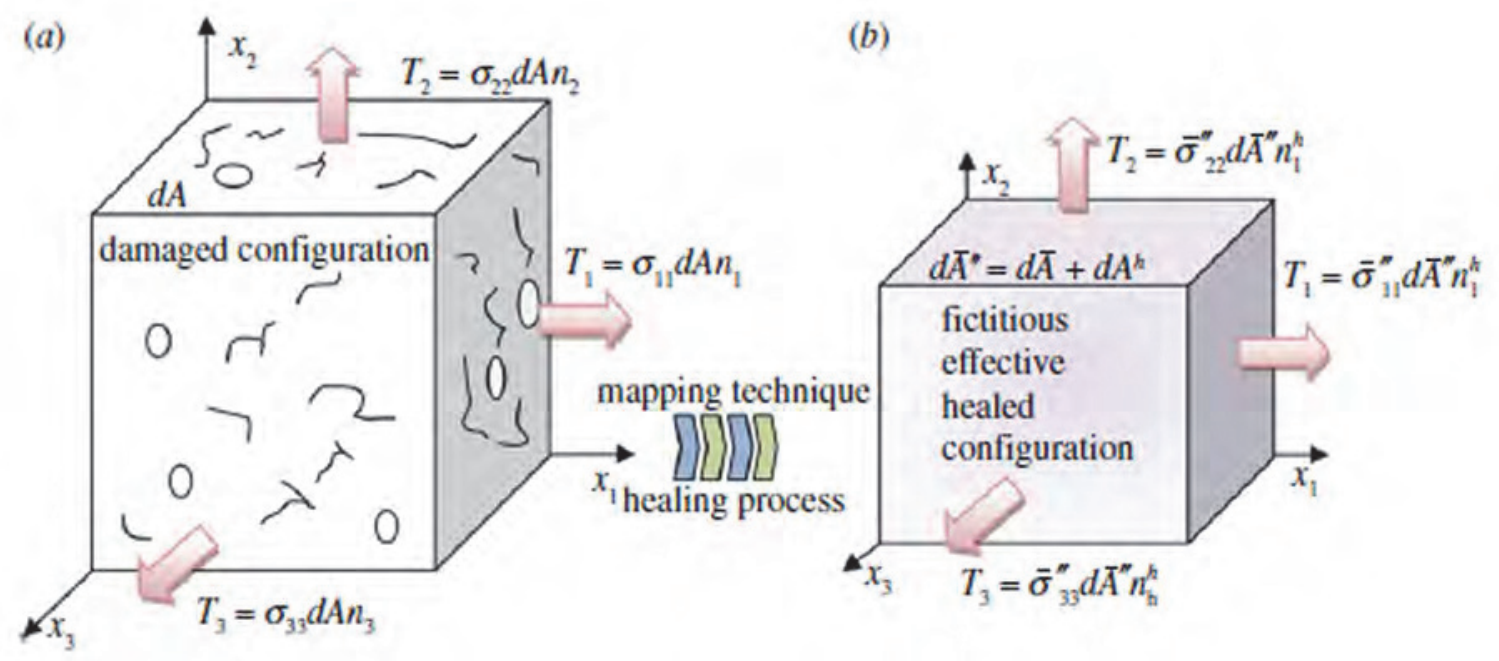

Fig 13. The overall mapping procedure between the real damaged and fictitious healed effective configurations: (a) damaged configuration, (b) fictitious effective configuration after the healing process. [311], Copyright 2012. Reproduced with permission from the Royal Society of Chemistry. 
a)

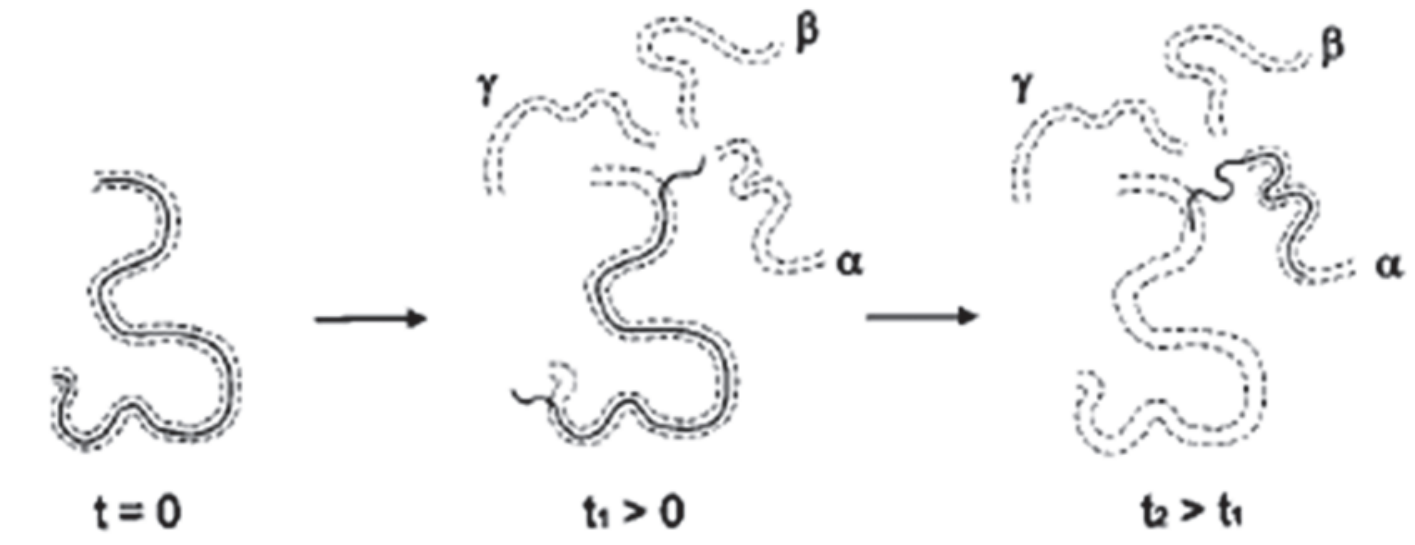

b)
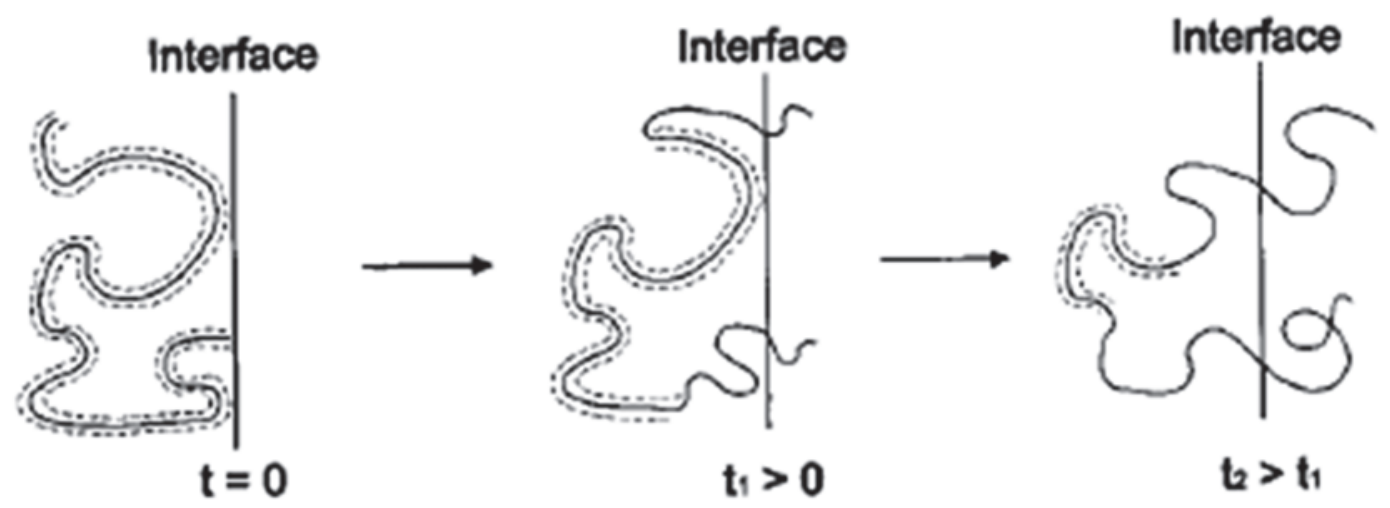

c)
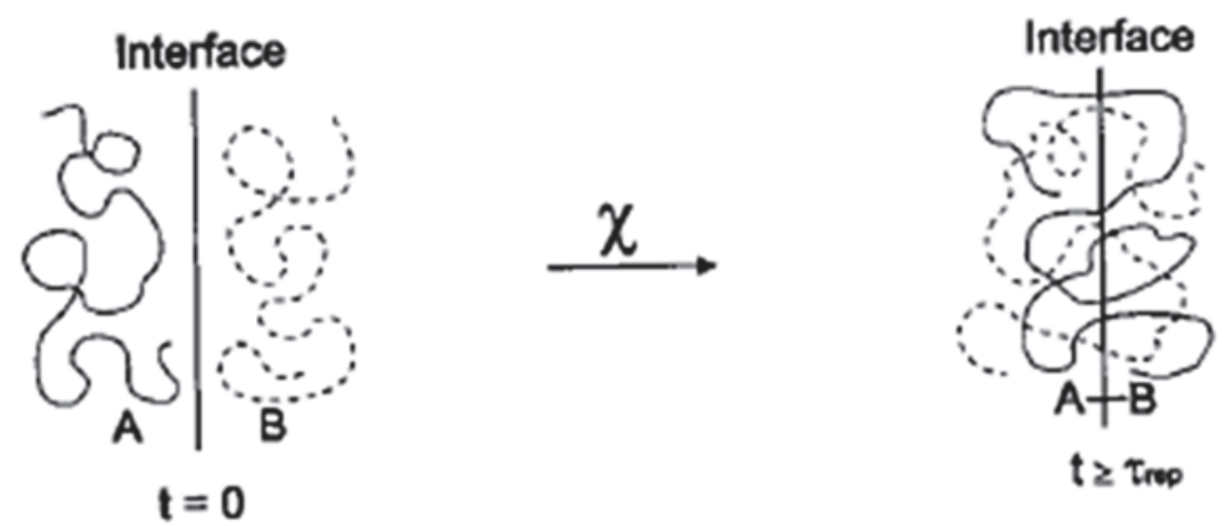

$t \geq \tau_{\text {rop }}$

Fig 14. Reptation model for molecular diffusion and randomization behavior across the interface during healing. [321], Copyright 1998. Reproduced with permission from the American Chemical Society. 
Table 1 Healing-on-demand polymers investigated during 2007-2015

(NM: not mentioned)

\begin{tabular}{|c|c|c|c|c|c|c|c|c|c|}
\hline Polymer Entry & $\begin{array}{l}\text { Damage } \\
\text { Type }\end{array}$ & $\begin{array}{l}\text { Crack Approaching } \\
\text { Method }\end{array}$ & Healing Mechanism & $\begin{array}{l}\text { Healing } \\
\text { Measurement }\end{array}$ & Efficiency & $\begin{array}{l}\text { Repeatable } \\
(\mathrm{Y} / \mathrm{N})\end{array}$ & $\begin{array}{l}\text { Healing } \\
\text { Condition } \\
\end{array}$ & Time & Ref. \\
\hline $\begin{array}{l}\text { PEMAA } \\
\text { Copolymers }\end{array}$ & $\begin{array}{l}\text { a) sawing or } \\
\text { cutting; b) } \\
\text { puncture }\end{array}$ & $\begin{array}{l}\text { a) put together } \\
\text { manually; b) elastic } \\
\text { recovery }\end{array}$ & $\begin{array}{l}\text { interdiffusion due to } \\
\text { friction induced heat }\end{array}$ & $\begin{array}{l}\text { pressurized } \\
\text { burst test }\end{array}$ & NM & $\mathrm{Y}$ & $\begin{array}{l}\text { at }-30 \text { to } \\
25^{\circ} \mathrm{C}\end{array}$ & NM & $\begin{array}{l}{[100} \\
101]\end{array}$ \\
\hline $\begin{array}{l}\text { Ionomers Surlyn } \\
8940 \AA\end{array}$ & $\begin{array}{l}\text { ballistic } \\
\text { impact }\end{array}$ & $\begin{array}{l}\text { "shape memory" } \\
\text { effect }\end{array}$ & interdiffusion & $\begin{array}{l}\text { fractional } \\
\text { elastic } \\
\text { healing ratio }\end{array}$ & over $90 \%$ & $\mathrm{Y}$ & $\begin{array}{l}\text { above } \\
105^{\circ} \mathrm{C}\end{array}$ & $500 \mathrm{~s}$ & $\begin{array}{l}{[102-} \\
104]\end{array}$ \\
\hline ENR & $\begin{array}{l}\text { ballistic } \\
\text { impact }\end{array}$ & elastic recovery & $\begin{array}{l}\text { interdiffusion due to } \\
\text { friction induced heat }\end{array}$ & $\begin{array}{l}\text { pressurized } \\
\text { air flow }\end{array}$ & NM & NM & at RT & NM & {$[105]$} \\
\hline $\begin{array}{l}\text { Ionomer blends of } \\
\text { EMNa and } \\
\text { EMZn+ENR }\end{array}$ & $\begin{array}{l}\text { ballistic } \\
\text { impact }\end{array}$ & elastic recovery & $\begin{array}{l}\text { interdiffusion due to } \\
\text { friction induced heat }\end{array}$ & $\begin{array}{l}\text { pressurized } \\
\text { air flow }\end{array}$ & NM & NM & at RT & NM & {$[106]$} \\
\hline $\begin{array}{l}\text { PDMAA and } \\
\text { PNIPA hydrogel }\end{array}$ & cut & $\begin{array}{l}\text { put together } \\
\text { manually }\end{array}$ & $\begin{array}{l}\text { interdiffusion and } \\
\text { hydrogen bonding }\end{array}$ & $\begin{array}{l}\text { tensile peak } \\
\text { load }\end{array}$ & $100 \%$ & NM & $25-80^{\circ} \mathrm{C}$ & $\begin{array}{l}0.3 \text { to } \\
100 \mathrm{~h}\end{array}$ & {$[73]$} \\
\hline bPEI/PAA polymer & cut & $\begin{array}{l}\text { flow to contact in } \\
\text { water }\end{array}$ & $\begin{array}{l}\text { polyelectrolyte } \\
\text { diffusion }\end{array}$ & $\begin{array}{l}\text { cyclic } \\
\text { voltammetry }\end{array}$ & NM & NM & $\begin{array}{l}\text { in water at } \\
\text { RT }\end{array}$ & $\begin{array}{l}5 \\
\min \\
\text { to } \\
24 \mathrm{~h}\end{array}$ & {$[76]$} \\
\hline PAA/PAH CoPECs & $\begin{array}{l}\text { cut into } \\
\text { pieces }\end{array}$ & $\begin{array}{l}\text { put together } \\
\text { manually }\end{array}$ & interdiffusion & $\begin{array}{l}\text { tensile peak } \\
\text { stress }\end{array}$ & $100 \%$ & NM & $\begin{array}{l}\text { in } \mathrm{NaCl} \\
\text { solution }\end{array}$ & $\begin{array}{l}\text { over } \\
3 \mathrm{~h}\end{array}$ & {$[65]$} \\
\hline $\begin{array}{l}\text { LMWOs based } \\
\text { supramolecular gel }\end{array}$ & $\begin{array}{l}\text { cut into } \\
\text { pieces }\end{array}$ & $\begin{array}{l}\text { put together } \\
\text { manually }\end{array}$ & interdiffusion & $\begin{array}{l}\text { visual } \\
\text { observation }\end{array}$ & NM & NM & at RT & $\begin{array}{l}\text { over } \\
\text { two } \\
\text { days }\end{array}$ & {$[92]$} \\
\hline $\begin{array}{l}\text { n-butyl acrylate } \\
\text { based zinc ionomer } \\
\text { with magnetic } \\
\text { nanoparticles }\end{array}$ & $\begin{array}{l}\text { cut into } \\
\text { pieces }\end{array}$ & $\begin{array}{l}\text { put together } \\
\text { manually }\end{array}$ & interdiffusion & $\begin{array}{l}\text { tensile } \\
\text { strength or } \\
\text { tensile strain }\end{array}$ & $90 \%$ & NM & $\begin{array}{l}70^{\circ} \mathrm{C} \text { or in } \\
\text { magnetic } \\
\text { field }\end{array}$ & $\begin{array}{l}30 \mathrm{~m} \\
\text { or } \\
15 \mathrm{~m}\end{array}$ & {$[107]$} \\
\hline A6ACA hydrogels & cut & $\begin{array}{l}\text { put together } \\
\text { manually }\end{array}$ & $\begin{array}{l}\text { reversible hydrogen } \\
\text { bond of terminal- } \\
\text { carboxyl groups }\end{array}$ & $\begin{array}{l}\text { fracture } \\
\text { stress }\end{array}$ & $66 \pm 7 \%$ & $\mathrm{Y}$ & $\begin{array}{l}\text { in } \mathrm{pH} \\
\text { solution } \\
(\mathrm{pH}<3)\end{array}$ & $24 \mathrm{~h}$ & {$[63]$} \\
\hline
\end{tabular}




\begin{tabular}{|c|c|c|c|c|c|c|c|c|c|}
\hline $\begin{array}{l}\text { Fatty acids and } \\
\text { urea based rubbers }\end{array}$ & cut & $\begin{array}{l}\text { put together } \\
\text { manually }\end{array}$ & $\begin{array}{l}\text { hydrogen bond re- } \\
\text { association }\end{array}$ & $\begin{array}{l}\text { tensile } \\
\text { strength }\end{array}$ & NM & $\mathrm{Y}$ & at RT & $3 \mathrm{~h}$ & {$[87]$} \\
\hline $\begin{array}{l}\text { UPy-unit based } \\
\text { supramolecular } \\
\text { polymers }\end{array}$ & $\begin{array}{l}\text { cut into } \\
\text { pieces }\end{array}$ & $\begin{array}{l}\text { put together under } \\
\text { pressure }\end{array}$ & $\begin{array}{l}\text { reversible UPy } \\
\text { hydrogen bonds }\end{array}$ & $\begin{array}{l}\text { visual } \\
\text { observation }\end{array}$ & NM & $\mathrm{Y}$ & at RT & $10 \mathrm{~s}$ & {$[90]$} \\
\hline $\begin{array}{l}\text { PDMSs based } \\
\text { supramolecular } \\
\text { elastomers }\end{array}$ & $\begin{array}{l}\text { cut into } \\
\text { pieces }\end{array}$ & $\begin{array}{l}\text { put together under } \\
\text { pressure }\end{array}$ & $\begin{array}{l}\text { hydrogen bond re- } \\
\text { association }\end{array}$ & $\begin{array}{l}\text { tensile } \\
\text { strength }\end{array}$ & $86 \%$ & NM & at RT & $24 \mathrm{~h}$ & {$[91]$} \\
\hline $\begin{array}{l}\text { Amino acid based } \\
\text { metallohydrogels }\end{array}$ & $\begin{array}{l}\text { cut into } \\
\text { pieces }\end{array}$ & $\begin{array}{l}\text { put together } \\
\text { manually }\end{array}$ & $\begin{array}{l}\text { multiple hydrogen } \\
\text { bonding interaction }\end{array}$ & $\begin{array}{l}\text { visual } \\
\text { observation }\end{array}$ & NM & $\mathrm{Y}$ & at RT & $3 \mathrm{~h}$ & {$[108]$} \\
\hline $\begin{array}{l}\text { PMMA based } \\
\text { copolymer }\end{array}$ & $\begin{array}{l}\text { cut into } \\
\text { pieces }\end{array}$ & $\begin{array}{l}\text { put together } \\
\text { manually }\end{array}$ & $\begin{array}{l}\text { hydrogen bonding } \\
\text { between PA-amide } \\
\text { groups }\end{array}$ & $\begin{array}{l}\text { tensile } \\
\text { strength }\end{array}$ & $70-90 \%$ & $\mathrm{Y}$ & $60^{\circ} \mathrm{C}$ & $24 \mathrm{~h}$ & {$[109]$} \\
\hline $\begin{array}{l}\text { TDI based } \\
\text { polyurethane }\end{array}$ & $\begin{array}{l}\text { tensile } \\
\text { fracture }\end{array}$ & $\begin{array}{l}\text { put together } \\
\text { manually }\end{array}$ & $\begin{array}{l}\text { hydrogen bonding } \\
\text { and chain segment } \\
\text { movement }\end{array}$ & $\begin{array}{l}\text { tensile } \\
\text { strength }\end{array}$ & $82 \%$ & $\mathrm{Y}$ & at RT & $\begin{array}{l}1 \\
\text { week }\end{array}$ & {$[110]$} \\
\hline $\begin{array}{l}\text { PMMA-PA-amide } \\
\text { copolymer }\end{array}$ & $\begin{array}{l}\text { cut into } \\
\text { pieces }\end{array}$ & $\begin{array}{l}\text { put together } \\
\text { manually }\end{array}$ & $\begin{array}{l}\text { multivalent hydrogen } \\
\text { bonds between soft } \\
\text { PA-amide brushes }\end{array}$ & tensile strain & $80 \%$ & NM & at RT & $24 \mathrm{~h}$ & [111] \\
\hline $\begin{array}{l}\text { Four-arm star } \\
\text { bromide-telechelic } \\
\text { polymers }\end{array}$ & $\begin{array}{l}\text { cut into } \\
\text { pieces }\end{array}$ & $\begin{array}{l}\text { put together } \\
\text { manually }\end{array}$ & $\begin{array}{l}\text { hydrogen bonding } \\
\text { interaction between } \\
\text { supramolecular } \\
\text { clusters and covalent } \\
\text { crosslinking via } \\
\text { CuAAC }\end{array}$ & $\begin{array}{l}\text { visual } \\
\text { observation }\end{array}$ & NM & $\mathrm{Y}$ & $40^{\circ} \mathrm{C}$ & $24 \mathrm{~h}$ & {$[112]$} \\
\hline $\begin{array}{l}\text { Copper- } \\
\text { coordination } \\
\text { polymer network } \\
\text { PIE }\end{array}$ & $\begin{array}{l}\text { cut into } \\
\text { pieces }\end{array}$ & $\begin{array}{l}\text { put together } \\
\text { manually }\end{array}$ & $\begin{array}{l}\text { restructuring of } \\
\text { copper-coordination } \\
\text { bonds and } \\
\text { rearrangement of } \\
\text { molecular chains }\end{array}$ & $\begin{array}{l}\text { tensile } \\
\text { strength }\end{array}$ & $92 \%$ & $\mathrm{Y}$ & $\begin{array}{l}\text { with } 5 \% \\
\text { water at } \\
45^{\circ} \mathrm{C}\end{array}$ & $1 \mathrm{~h}$ & {$[113]$} \\
\hline Mendomer 401 & bending & $\begin{array}{l}\text { put back into } \\
\text { contact }\end{array}$ & $\begin{array}{l}\text { reversible Diels- } \\
\text { Alder reaction }\end{array}$ & microscopes & NM & NM & $110^{\circ} \mathrm{C}$ & $\begin{array}{l}10 \\
\min \end{array}$ & {$[67]$} \\
\hline Thermosetting PK- & bending & compress into & DA and Retro-DA & three-point & $72.3 \%$ & NM & $120^{\circ} \mathrm{C}$ & 20 & {$[68]$} \\
\hline
\end{tabular}




\begin{tabular}{|c|c|c|c|c|c|c|c|c|c|}
\hline furan & & contract & & bending load & & & & $\min$ & \\
\hline $\begin{array}{l}\text { Bis(hydroxymethyl } \\
\text { ) furan based } \\
\text { polymer: poly }(2,5- \\
\text { furandimethylene } \\
\text { succinate) with } \\
\text { Bismaleimide }\end{array}$ & $\begin{array}{l}\text { tensile } \\
\text { fracture }\end{array}$ & $\begin{array}{l}\text { put together under } \\
\text { pressure }\end{array}$ & $\begin{array}{l}\text { reversible DA } \\
\text { reaction between PFS } \\
\text { and } \mathrm{M}_{2}\end{array}$ & $\begin{array}{l}\text { tensile } \\
\text { toughness }\end{array}$ & $72.3 \%$ & $\mathrm{NM}$ & at RT & $\begin{array}{l}1-10 \\
\text { days }\end{array}$ & [99] \\
\hline $\begin{array}{l}\text { Spherosilicate } \\
\text { based polymer }\end{array}$ & $\begin{array}{l}\text { cut into } \\
\text { pieces }\end{array}$ & $\begin{array}{l}\text { put together } \\
\text { manually }\end{array}$ & $\begin{array}{l}\text { reversible DA } \\
\text { reactions }\end{array}$ & $\begin{array}{l}\text { transmission } \\
\text { light } \\
\text { microscopy }\end{array}$ & NM & NM & $135^{\circ} \mathrm{C}$ & $\begin{array}{l}10 \\
\min \end{array}$ & {$[114]$} \\
\hline $\begin{array}{l}\text { Thiourethane based } \\
\text { crosslinked } \\
\text { polycaprolactone } \\
\text { polymer }\end{array}$ & cut & $\begin{array}{l}\text { bring together due } \\
\text { to shape memory } \\
\text { effect }\end{array}$ & $\begin{array}{l}\text { reversible DA } \\
\text { reaction between } \\
\text { trisfuranic } \\
\text { thiourethane and } \\
\text { trimaleimidic } \\
\text { urethane }\end{array}$ & $\begin{array}{l}\text { tensile } \\
\text { strength }\end{array}$ & $90 \%$ & $\mathrm{Y}$ & $60^{\circ} \mathrm{C}$ & $24 \mathrm{~h}$ & {$[115]$} \\
\hline $\begin{array}{l}\text { CDTE/Cp based } \\
\text { polymer }\end{array}$ & $\begin{array}{l}\text { cut into } \\
\text { pieces }\end{array}$ & press into together & $\begin{array}{l}\text { Hetero DA reactions } \\
\text { between CDTE and } \\
\text { Cp }\end{array}$ & $\begin{array}{l}\text { tensile } \\
\text { strength }\end{array}$ & $98 \%$ & $\mathrm{Y}$ & $120^{\circ} \mathrm{C}$ & $\begin{array}{l}10 \\
\min \end{array}$ & {$[116]$} \\
\hline $\begin{array}{l}\text { Polyurethane } \\
\text { elastomer }\end{array}$ & $\begin{array}{l}\text { cut into } \\
\text { pieces }\end{array}$ & $\begin{array}{l}\text { put together } \\
\text { manually }\end{array}$ & $\begin{array}{l}\text { reversible fission / } \\
\text { recombination of C- } \\
\text { ON bonds in } \\
\text { alkoxyamine }\end{array}$ & $\begin{array}{l}\text { tensile } \\
\text { strength }\end{array}$ & $70 \%$ & $\mathrm{Y}$ & $\begin{array}{l}80^{\circ} \mathrm{C} \text { in } \\
\text { argon }\end{array}$ & $2.5 \mathrm{~h}$ & [117] \\
\hline $\begin{array}{l}\text { Supramolecular } \\
\text { DB24C8 gels }\end{array}$ & $\begin{array}{l}\text { accidental } \\
\text { damage }\end{array}$ & $\begin{array}{l}\text { put together } \\
\text { manually }\end{array}$ & $\begin{array}{l}\text { crown ether based } \\
\text { host-guest interaction }\end{array}$ & $\begin{array}{l}\text { rheological } \\
\text { measurement } \\
\text { on modulus }\end{array}$ & $\begin{array}{l}\text { above } \\
95 \%\end{array}$ & $\mathrm{NM}$ & at RT & $\begin{array}{l}10 \text { to } \\
30 \mathrm{~s}\end{array}$ & {$[62]$} \\
\hline $\begin{array}{l}\text { pAA based } \\
\text { supramolecular } \\
\text { hydrogels }\end{array}$ & $\begin{array}{l}\text { cut into } \\
\text { pieces }\end{array}$ & $\begin{array}{l}\text { put together } \\
\text { manually }\end{array}$ & $\begin{array}{l}\text { host-guest interaction } \\
\text { between pAA-CDs } \\
\text { and pAA-Fc }\end{array}$ & $\begin{array}{l}\text { wedge-shape } \\
\text { strain } \\
\text { compression } \\
\text { test on } \\
\text { adhesion } \\
\text { strength }\end{array}$ & $84 \%$ & $\mathrm{NM}$ & at RT & $24 \mathrm{~h}$ & $\begin{array}{l}{[95} \\
96]\end{array}$ \\
\hline $\begin{array}{l}\text { CD/VI based } \\
\text { supramolecular }\end{array}$ & $\begin{array}{l}\text { cut into } \\
\text { pieces }\end{array}$ & $\begin{array}{l}\text { put together } \\
\text { manually }\end{array}$ & $\begin{array}{l}\text { host-guest between } \\
\text { CD and p(VA-co- }\end{array}$ & $\begin{array}{l}\text { tensile } \\
\text { modulus }\end{array}$ & $92 \%$ & $\mathrm{Y}$ & $\begin{array}{l}\text { under } \\
\text { magnetic }\end{array}$ & $3 \mathrm{~h}$ & {$[118]$} \\
\hline
\end{tabular}




\begin{tabular}{|c|c|c|c|c|c|c|c|c|c|}
\hline gels & & & HPA) & & & & field at RT & & \\
\hline$\beta$-CD-Ad hydrogel & $\begin{array}{l}\text { cut into } \\
\text { pieces }\end{array}$ & $\begin{array}{l}\text { put together } \\
\text { manually }\end{array}$ & $\begin{array}{l}\text { host-guest } \\
\text { interactions between } \\
\text { CD exrogel and Ad } \\
\text { exrogel }\end{array}$ & tensile stress & $88 \%$ & $\mathrm{Y}$ & $\begin{array}{l}\text { with water } \\
\text { at RT }\end{array}$ & $48 \mathrm{~h}$ & [119] \\
\hline $\begin{array}{l}\text { covalently } \\
\text { corsslinked rubber }\end{array}$ & cut & $\begin{array}{l}\text { put together } \\
\text { manually }\end{array}$ & $\begin{array}{l}\text { disulfide interchange } \\
\text { reaction }\end{array}$ & $\begin{array}{l}\text { tensile peak } \\
\text { load }\end{array}$ & $100 \%$ & NM & $80^{\circ} \mathrm{C}$ & $2 \mathrm{~h}$ & {$[72]$} \\
\hline $\begin{array}{l}\text { TTC based } \\
\text { crosslinked } \\
\text { polemer }\end{array}$ & $\begin{array}{l}\text { cut into } \\
\text { pieces }\end{array}$ & $\begin{array}{l}\text { put together under } \\
\text { pressure }\end{array}$ & $\begin{array}{l}\text { reshuffling reactions } \\
\text { of trithiocarbonate } \\
\text { units }\end{array}$ & $\begin{array}{l}\text { tensile } \\
\text { modulus }\end{array}$ & $94 \pm 18 \%$ & $\mathrm{Y}$ & $\begin{array}{l}\text { in } \\
\text { nitrogen } \\
\text { under UV }\end{array}$ & $4 \mathrm{~h}$ & [79] \\
\hline $\begin{array}{l}\text { TDS based } \\
\text { crosslinked } \\
\text { polymer }\end{array}$ & $\begin{array}{l}\text { cut into } \\
\text { pieces }\end{array}$ & $\begin{array}{l}\text { put together under } \\
\text { pressure }\end{array}$ & $\begin{array}{l}\text { reshuffling Thiuram } \\
\text { Disulfide moieties }\end{array}$ & $\begin{array}{l}\text { peak tensile } \\
\text { stress }\end{array}$ & $97 \%$ & NM & $\begin{array}{l}\text { in air } \\
\text { under } \\
\text { visible } \\
\text { light }\end{array}$ & $24 \mathrm{~h}$ & {$[82]$} \\
\hline $\begin{array}{l}\text { Crosslinked cPEG } \\
\text { hydrogel }\end{array}$ & cut & $\begin{array}{l}\text { put together } \\
\text { manually }\end{array}$ & $\begin{array}{l}\text { reversible boronic- } \\
\text { catechol } \\
\text { complexation }\end{array}$ & $\begin{array}{l}\text { visual } \\
\text { observation }\end{array}$ & NM & NM & at RT & & {$[61]$} \\
\hline $\begin{array}{l}\text { covalent } \\
\text { crosslinked } \\
\text { polymer gels }\end{array}$ & cut & $\begin{array}{l}\text { put together } \\
\text { manually }\end{array}$ & $\begin{array}{l}\text { reversible covalent } \\
\text { acylhydrazone bonds }\end{array}$ & $\begin{array}{l}\text { visual } \\
\text { observation }\end{array}$ & NM & NM & at RT & $7 \mathrm{~h}$ & {$[60]$} \\
\hline $\begin{array}{l}\text { DOPA-Fe } \\
\text { crosslinked } \\
\text { hydrogel }\end{array}$ & cut & $\begin{array}{l}\text { put together } \\
\text { manually }\end{array}$ & $\begin{array}{l}\text { redox covalent } \\
\text { crosslinking }\end{array}$ & $\begin{array}{l}\text { dynamic } \\
\text { oscillatory } \\
\text { rheology on } \\
\text { storage } \\
\text { modulus }\end{array}$ & $124 \%$ & $\mathrm{Y}$ & in $\mathrm{pH}>8$ & $\begin{array}{l}45 \\
\min \end{array}$ & {$[64]$} \\
\hline $\begin{array}{l}\text { Boronic esters } \\
\text { based crosslinked } \\
\text { polymer }\end{array}$ & $\begin{array}{l}\text { cut into } \\
\text { pieces }\end{array}$ & $\begin{array}{l}\text { put together } \\
\text { manually }\end{array}$ & $\begin{array}{l}\text { reversible and } \\
\text { exchangeable } \\
\text { covalent bonds in } \\
\text { boronic esters }\end{array}$ & $\begin{array}{l}\text { tensile } \\
\text { strength }\end{array}$ & $89 \%$ & $\mathrm{Y}$ & $\begin{array}{l}\text { with water } \\
\text { at RT }\end{array}$ & $\begin{array}{l}3 \\
\text { days }\end{array}$ & [120] \\
\hline $\begin{array}{l}\text { Stearyl } \\
\text { methacrylate }(\mathrm{C} 18) \\
\text { based hygrogel }\end{array}$ & $\begin{array}{l}\text { cut into } \\
\text { pieces }\end{array}$ & $\begin{array}{l}\text { put together } \\
\text { manually }\end{array}$ & $\begin{array}{l}\text { reversible } \\
\text { dissociation- } \\
\text { assocation of } \mathrm{C} 18 \\
\text { network }\end{array}$ & $\begin{array}{l}\text { uniaxial } \\
\text { elongation } \\
\text { measurement }\end{array}$ & $100 \%$ & NM & at RT & $10 \mathrm{~s}$ & $\begin{array}{l}{[93} \\
94]\end{array}$ \\
\hline DABBF based gel & cut into & put together & dynamic radical & tensile & $98 \%$ & $\mathrm{NM}$ & under air & $24 \mathrm{~h}$ & [98] \\
\hline
\end{tabular}




\begin{tabular}{|c|c|c|c|c|c|c|c|c|c|}
\hline & pieces & manually & $\begin{array}{l}\text { exchange reaction of } \\
\text { DABBF units }\end{array}$ & strength & & & at RT & & \\
\hline $\begin{array}{l}\text { Dihydroxyl } \\
\text { coumarin based } \\
\text { polyurethane }\end{array}$ & $\begin{array}{l}\text { tensile } \\
\text { fracture }\end{array}$ & $\begin{array}{l}\text { put together } \\
\text { manually }\end{array}$ & $\begin{array}{l}\text { reversible } \\
\text { photoreactivity } \\
\text { coumarin }\end{array}$ & $\begin{array}{l}\text { tensile } \\
\text { strength }\end{array}$ & $64.4 \%$ & NM & $\begin{array}{l}254 \mathrm{~nm} \\
\text { UV first } \\
\text { then } 350 \\
\text { nm UV }\end{array}$ & $>2 \mathrm{~h}$ & [83] \\
\hline $\begin{array}{l}\text { POM based hybrid } \\
\text { hydrogels }\end{array}$ & $\begin{array}{l}\text { cut into } \\
\text { pieces }\end{array}$ & $\begin{array}{l}\text { put together under } \\
\text { pressure }\end{array}$ & $\begin{array}{l}\text { electrostatic } \\
\text { interaction between } \\
\text { the cationic PG and } \\
\text { the anionic EuW10 }\end{array}$ & $\begin{array}{l}\text { visual } \\
\text { observation }\end{array}$ & $\mathrm{NM}$ & $\mathrm{Y}$ & $\begin{array}{l}\text { with water } \\
\text { at RT }\end{array}$ & $\begin{array}{l}3 \\
\min \end{array}$ & [121] \\
\hline $\begin{array}{l}\text { Amide-containing } \\
\text { cyclooctene } \\
\text { network based } \\
\text { polymer }\end{array}$ & cut & $\begin{array}{l}\text { put together under } \\
\text { pressure }\end{array}$ & $\begin{array}{l}\text { dynamic olefin } \\
\text { metathesis reaction }\end{array}$ & $\begin{array}{l}\text { tensile } \\
\text { toughness }\end{array}$ & $90 \%$ & NM & $50^{\circ} \mathrm{C}$ & $3 \mathrm{~h}$ & [122] \\
\hline
\end{tabular}


Table 2 Chemical covalent bond reactions for crack healing application.

Entry Covalent Bond Molecular Chain Reactions

a)

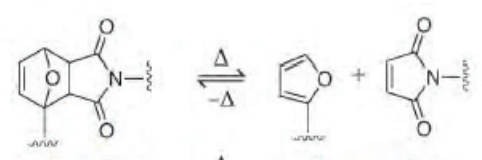

2 reversible Diels-
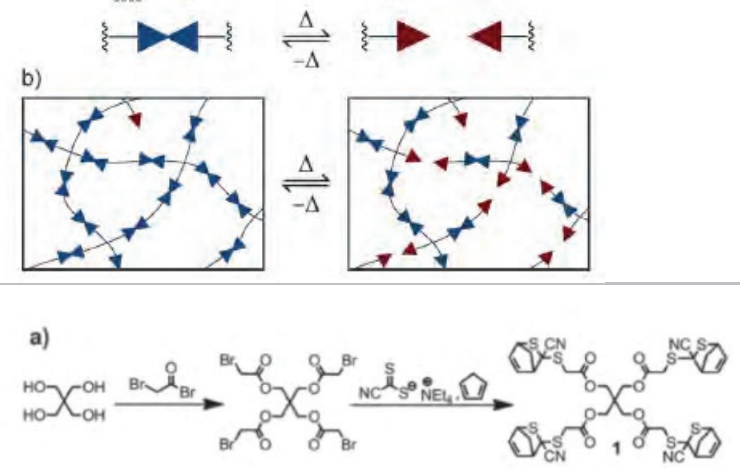

3 hetero Diels-

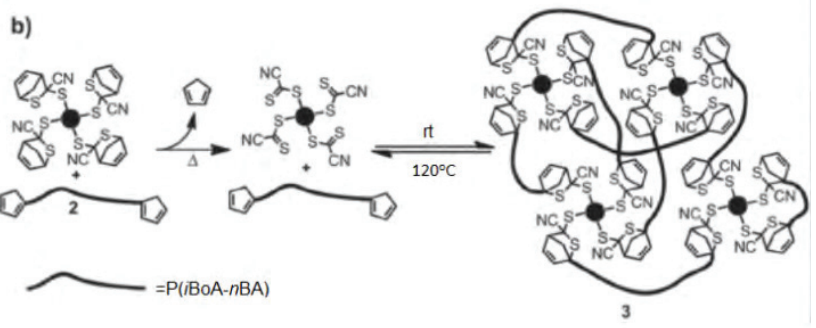

(a)

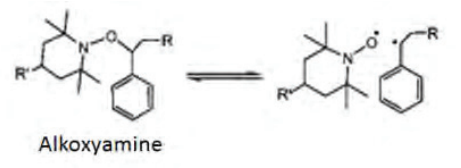

4

reversible $\mathrm{C}-\mathrm{ON}$ bonds

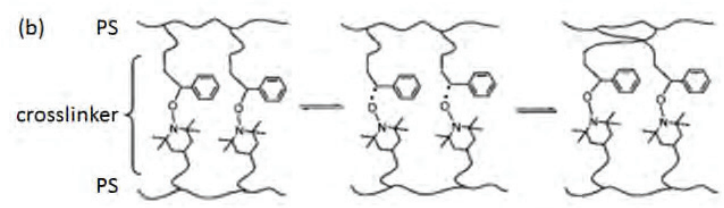




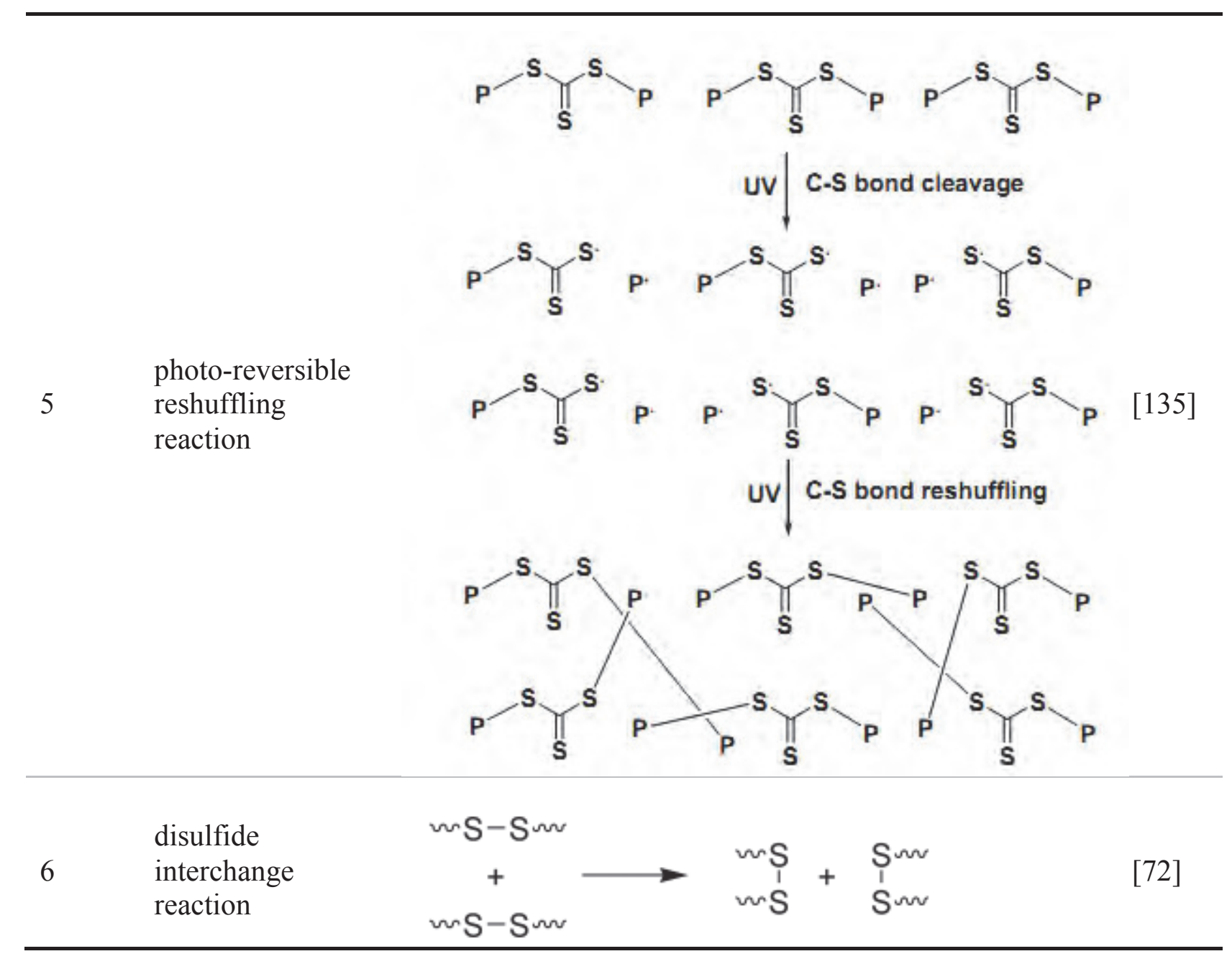




\begin{tabular}{|c|c|c|c|c|c|c|c|c|c|}
\hline $\begin{array}{l}\text { Composite } \\
\text { Type }\end{array}$ & $\begin{array}{l}\text { Damage } \\
\text { Type }\end{array}$ & $\begin{array}{l}\text { Crack Approaching } \\
\text { Method }\end{array}$ & $\begin{array}{l}\text { Healing } \\
\text { Mechanism }\end{array}$ & $\begin{array}{l}\text { Healing } \\
\text { Measurement }\end{array}$ & Efficiency & $\begin{array}{l}\text { Repeatable } \\
(\mathrm{Y} / \mathrm{N})\end{array}$ & $\begin{array}{l}\text { Healing } \\
\text { Condition }\end{array}$ & Time & Ref \\
\hline $\begin{array}{l}\text { micro- } \\
\text { capsulated } \\
\text { polymer } \\
\text { composite }\end{array}$ & $\begin{array}{l}\text { TDCB } \\
\text { fracture } \\
\text { test }\end{array}$ & $\begin{array}{l}\text { release of healing } \\
\text { agent DCPD from } \\
\text { microcapsule }\end{array}$ & $\begin{array}{l}\text { ROMP polymerization } \\
\text { of DCPD with solid } \\
\text { Grubbs' catalyst (I) }\end{array}$ & $\begin{array}{l}\text { mode-I } \\
\text { fracture } \\
\text { toughness }\end{array}$ & $>75 \%$ & $\mathrm{~N}$ & RT & $>24 h$ & $\begin{array}{l}{[171-} \\
180]\end{array}$ \\
\hline $\begin{array}{l}\text { micro- } \\
\text { capsulated } \\
\text { polymer } \\
\text { composite }\end{array}$ & $\begin{array}{l}\text { TDCB } \\
\text { fracture } \\
\text { test }\end{array}$ & $\begin{array}{l}\text { release of healing } \\
\text { agent DCPD from } \\
\text { microcapsule }\end{array}$ & $\begin{array}{l}\text { ROMP polymerization } \\
\text { of DCPD with solid } \\
\text { Grubbs' catalyst (I) }\end{array}$ & fatigue life & $213 \%$ & $\mathrm{~N}$ & RT & $>10 \mathrm{~h}$ & $\begin{array}{l}{[181-} \\
183]\end{array}$ \\
\hline $\begin{array}{l}\text { micro- } \\
\text { capsulated } \\
\text { polymer } \\
\text { composite }\end{array}$ & $\begin{array}{l}\text { TDCB } \\
\text { fracture } \\
\text { test }\end{array}$ & $\begin{array}{l}\text { release of healing } \\
\text { agent DCPD from } \\
\text { microcapsule }\end{array}$ & $\begin{array}{l}\text { ROMP polymerization } \\
\text { of DCPD with solid } \\
\text { Grubbs' catalyst (II) }\end{array}$ & fracture load & $84 \%$ & $\mathrm{~N}$ & $125^{\circ} \mathrm{C}$ & $24 \mathrm{~h}$ & [184] \\
\hline $\begin{array}{l}\text { micro- } \\
\text { capsulated } \\
\text { polymer } \\
\text { composite }\end{array}$ & $\begin{array}{l}\text { TDCB } \\
\text { fracture } \\
\text { test }\end{array}$ & $\begin{array}{l}\text { release of healing } \\
\text { agent DCPD from } \\
\text { microcapsule }\end{array}$ & $\begin{array}{l}\text { ROMP interaction of } \\
\text { exo-DCPD with waxed } \\
\mathrm{WCl}_{6}\end{array}$ & peak load & $80 \%$ & $\mathrm{~N}$ & RT & $48 \mathrm{~h}$ & [185] \\
\hline $\begin{array}{l}\text { micro- } \\
\text { capsulated } \\
\text { polymer } \\
\text { composite }\end{array}$ & $\begin{array}{l}\text { SENB } \\
\text { fracture } \\
\text { test }\end{array}$ & $\begin{array}{l}\text { release of healing } \\
\text { agent bisphenol-A } \\
\text { epoxy from } \\
\text { microcapsule and } \\
\text { with help of paper } \\
\text { clamps }\end{array}$ & $\begin{array}{l}\text { polymerization of } \\
\text { bisphenol-A epoxy } \\
\text { initiated by } \mathrm{CuBr}_{2}(2- \\
\mathrm{MeIm})_{4}\end{array}$ & $\begin{array}{l}\text { mode-I } \\
\text { fracture } \\
\text { toughness }\end{array}$ & $>40 \%$ & $\mathrm{~N}$ & $130^{\circ} \mathrm{C}$ & $>0.5 \mathrm{~h}$ & $\begin{array}{l}{[186-} \\
189]\end{array}$ \\
\hline $\begin{array}{l}\text { micro- } \\
\text { capsulated } \\
\text { polymer } \\
\text { composite }\end{array}$ & $\begin{array}{l}\text { micro- } \\
\text { cracks } \\
\text { by } \\
\text { pressing }\end{array}$ & $\begin{array}{l}\text { release of healing } \\
\text { agent MAT-PDMS } \\
\text { from microcapsule }\end{array}$ & $\begin{array}{l}\text { photopolymerization of } \\
\text { MAT-PDMS initiated } \\
\text { by BIE photoinitiator }\end{array}$ & $\begin{array}{l}\text { water } \\
\text { permeability } \\
\text { test and } \\
\text { chloride ion } \\
\text { penetration } \\
\text { test }\end{array}$ & NM & $\mathrm{Y}$ & $\begin{array}{l}\text { under } \\
\text { sunlight }\end{array}$ & $4 \mathrm{~h}$ & [190] \\
\hline
\end{tabular}




\begin{tabular}{|c|c|c|c|c|c|c|c|c|c|}
\hline $\begin{array}{l}\text { micro- } \\
\text { capsulated } \\
\text { polymer } \\
\text { composite } \\
\end{array}$ & $\begin{array}{l}\text { impact } \\
\text { test }\end{array}$ & $\begin{array}{l}\text { release of EPON } \\
\text { epoxy from } \\
\text { microcapsule }\end{array}$ & $\begin{array}{l}\text { cationic chain } \\
\text { polymerization EPON } \\
\text { epoxy by fiber protected } \\
\left(\mathrm{C}_{2} \mathrm{H}_{5}\right)_{2} \mathrm{O} \cdot \mathrm{BF}_{3}\end{array}$ & $\begin{array}{l}\text { impact } \\
\text { strength }\end{array}$ & $>76 \%$ & $\mathrm{~N}$ & $20^{\circ} \mathrm{C}$ & $\begin{array}{l}30 \\
\min \end{array}$ & $\begin{array}{l}{[191,} \\
192]\end{array}$ \\
\hline $\begin{array}{l}\text { micro- } \\
\text { capsulated } \\
\text { polymer } \\
\text { composite }\end{array}$ & $\begin{array}{l}\text { Izod } \\
\text { impact } \\
\text { test }\end{array}$ & $\begin{array}{l}\text { release of GMA } \\
\text { from microcapsule }\end{array}$ & $\begin{array}{l}\text { polymerization of GMA } \\
\text { with living PMMA }\end{array}$ & $\begin{array}{l}\text { Izod impact } \\
\text { strength }\end{array}$ & $100 \%$ & $\mathrm{Y}$ & RT & $24 \mathrm{~h}$ & $\begin{array}{l}{[166,} \\
167]\end{array}$ \\
\hline $\begin{array}{l}\text { dual micro- } \\
\text { capsulated } \\
\text { polymer } \\
\text { composite }\end{array}$ & $\begin{array}{l}\text { impact } \\
\text { test }\end{array}$ & $\begin{array}{l}\text { release of healing } \\
\text { agent EPON } 828 \\
\text { and TfOH from } \\
\text { microcapsules }\end{array}$ & $\begin{array}{l}\text { cationic chain } \\
\text { polymerization of } \\
\text { EPON } 828 \text { by TfOH }\end{array}$ & $\begin{array}{l}\text { impact } \\
\text { strength }\end{array}$ & $79 \%$ & $\mathrm{~N}$ & RT & $100 \mathrm{~s}$ & [193] \\
\hline $\begin{array}{l}\text { dual micro- } \\
\text { capsulated } \\
\text { polymer } \\
\text { composite }\end{array}$ & $\begin{array}{l}\text { torsion } \\
\text { fatigue } \\
\text { test }\end{array}$ & $\begin{array}{l}\text { release of healing } \\
\text { agent PDMS and } \\
\text { liquid initiator from } \\
\text { microcapsules }\end{array}$ & $\begin{array}{l}\text { polymerization of } \\
\text { PDMS initiated by } \\
\text { platinum catalyst with } \\
\text { initiator }\end{array}$ & $\begin{array}{l}\text { fatigue crack } \\
\text { growth }\end{array}$ & $\begin{array}{l}24 \% \\
\text { reduction }\end{array}$ & NM & RT & $5 \mathrm{~h}$ & $\begin{array}{l}{[170,} \\
194- \\
197]\end{array}$ \\
\hline $\begin{array}{l}\text { dual micro- } \\
\text { capsulated } \\
\text { polymer } \\
\text { composite }\end{array}$ & $\begin{array}{l}\text { TDCB } \\
\text { fracture } \\
\text { test }\end{array}$ & $\begin{array}{l}\text { release of healing } \\
\text { agent epoxy and } \\
\text { curing hardener } \\
\text { from microcapsules }\end{array}$ & $\begin{array}{l}\text { curing hardening of } \\
\text { epoxy resin by } \\
\text { corresponding hardener }\end{array}$ & $\begin{array}{l}\text { mode-I } \\
\text { fracture } \\
\text { toughness }\end{array}$ & $>62 \%$ & $\mathrm{~N}$ & RT & $48 \mathrm{~h}$ & $\begin{array}{l}{[198-} \\
201]\end{array}$ \\
\hline $\begin{array}{l}\text { dual micro- } \\
\text { capsulated } \\
\text { polymer } \\
\text { composite }\end{array}$ & $\begin{array}{l}\text { TDCB } \\
\text { fracture } \\
\text { test }\end{array}$ & $\begin{array}{l}\text { release of catalyst } \\
\text { DBTL and healing } \\
\text { agent from } \\
\text { microcapsules }\end{array}$ & $\begin{array}{l}\text { polycondensation of } \\
\text { HOPDMS with PDES } \\
\text { initiated by DBTL }\end{array}$ & fracture load & $46 \%$ & NM & $50^{\circ} \mathrm{C}$ & $24 \mathrm{~h}$ & [202] \\
\hline $\begin{array}{l}\text { dual micro- } \\
\text { capsulated } \\
\text { polymer } \\
\text { composite }\end{array}$ & $\begin{array}{l}\text { 3-point } \\
\text { bending } \\
\text { test }\end{array}$ & $\begin{array}{l}\text { release of DTHP } \\
\text { and BDMA from } \\
\text { microcapsules }\end{array}$ & $\begin{array}{l}\text { polymerization of } \\
\text { DTHP by BDMA }\end{array}$ & fracture load & $93-117 \%$ & NM & $18-11^{\circ} \mathrm{C}$ & $17 \mathrm{~h}$ & [203] \\
\hline $\begin{array}{l}\text { dual micro- } \\
\text { capsulated } \\
\text { polymer }\end{array}$ & $\begin{array}{l}\text { Tensile } \\
\text { fracture } \\
\text { test }\end{array}$ & $\begin{array}{l}\text { release of azido- } \\
\text { telechlic three-arm } \\
\text { star PIB and } \\
\text { trivalent alkynes } \\
\text { from microcapsules }\end{array}$ & $\begin{array}{l}\text { azide/alkyne-"click" } \\
\text { reaction initiated by } \\
\mathrm{Cu}^{\mathrm{I}} \mathrm{Br}\left(\mathrm{PPh}_{3}\right)_{3}\end{array}$ & $\begin{array}{l}\text { tensile } \\
\text { storage } \\
\text { modulus }\end{array}$ & about $70 \%$ & NM & $40-80^{\circ} \mathrm{C}$ & $\begin{array}{l}380 \mathrm{~s}- \\
10 \\
\min \end{array}$ & $\begin{array}{l}{[204,} \\
205]\end{array}$ \\
\hline
\end{tabular}




\begin{tabular}{|c|c|c|c|c|c|c|c|c|c|}
\hline $\begin{array}{l}\text { dual micro- } \\
\text { capsulated } \\
\text { polymer } \\
\text { composite }\end{array}$ & $\begin{array}{l}\text { impact } \\
\text { test }\end{array}$ & $\begin{array}{l}\text { release of healing } \\
\text { agent PS and BPO } \\
\text { from microcapsules }\end{array}$ & $\begin{array}{l}\text { free radical } \\
\text { polymerization of PS } \\
\text { initiated by BPO }\end{array}$ & $\begin{array}{l}\text { impact } \\
\text { energy }\end{array}$ & $65 \%$ & $\mathrm{~N}$ & RT & $24 \mathrm{~h}$ & [206] \\
\hline $\begin{array}{l}\text { dual micro- } \\
\text { capsulated } \\
\text { polymer } \\
\text { composite } \\
\end{array}$ & $\begin{array}{l}\text { TDCB } \\
\text { fracture } \\
\text { test }\end{array}$ & $\begin{array}{l}\text { release of tetrathiol } \\
\text { reagent and } \\
\text { isocyanate reagent } \\
\text { from microcapsules }\end{array}$ & $\begin{array}{l}\text { covalent reaction of } \\
\text { Thiol-isocyanate }\end{array}$ & $\begin{array}{l}\text { fracture peak } \\
\text { load }\end{array}$ & $89-133 \%$ & $\mathrm{NM}$ & $\mathrm{RT}$ & $\begin{array}{l}24- \\
120 h\end{array}$ & [207] \\
\hline $\begin{array}{l}\text { hollow glass- } \\
\text { fiber } \\
\text { reinforced } \\
\text { polymer } \\
\text { composite }\end{array}$ & $\begin{array}{l}\text { 4-point } \\
\text { bending } \\
\text { test }\end{array}$ & $\begin{array}{l}\text { release of epoxy } \\
\text { resin and hardener } \\
\text { from hollow fiber } \\
\text { plies }\end{array}$ & $\begin{array}{l}\text { curing of epoxy resin by } \\
\text { corresponding hardener }\end{array}$ & $\begin{array}{l}\text { bending } \\
\text { strength }\end{array}$ & $>87 \%$ & $\mathrm{~N}$ & $\begin{array}{l}\text { RT- } \\
100^{\circ} \mathrm{C}\end{array}$ & $2-24 h$ & $\begin{array}{l}{[208-} \\
212]\end{array}$ \\
\hline $\begin{array}{l}\text { hollow glass- } \\
\text { fiber } \\
\text { reinforced } \\
\text { polymer } \\
\text { composite }\end{array}$ & $\begin{array}{l}\text { impact } \\
\text { test }\end{array}$ & $\begin{array}{l}\text { release of epoxy } \\
\text { resin and hardener } \\
\text { from hollow fiber } \\
\text { plies }\end{array}$ & $\begin{array}{l}\text { curing of epoxy resin by } \\
\text { corresponding hardener }\end{array}$ & $\begin{array}{l}\text { impact } \\
\text { strength }\end{array}$ & $>50 \%$ & $\mathrm{~N}$ & $\begin{array}{l}\mathrm{RT}- \\
125^{\circ} \mathrm{C}\end{array}$ & $\begin{array}{l}75 \\
\min - \\
96 h\end{array}$ & $\begin{array}{l}{[213-} \\
216]\end{array}$ \\
\hline $\begin{array}{l}\text { micro- } \\
\text { vascular } \\
\text { network in } \\
\text { polymer } \\
\text { composite }\end{array}$ & $\begin{array}{l}\text { 4-point } \\
\text { bending } \\
\text { test }\end{array}$ & $\begin{array}{l}\text { delivery of epoxy } \\
\text { resin and hardener } \\
\text { from liquid } \\
\text { reservoir through } \\
\text { 3D vascular } \\
\text { networks }\end{array}$ & $\begin{array}{l}\text { curing of epoxy by } \\
\text { corresponding hardener }\end{array}$ & fracture load & $>42 \%$ & $\mathrm{Y}$ & RT & $\begin{array}{l}12- \\
48 h\end{array}$ & $\begin{array}{l}{[217-} \\
221]\end{array}$ \\
\hline $\begin{array}{l}\text { vascular } \\
\text { network in } \\
\text { polymer } \\
\text { composite }\end{array}$ & $\begin{array}{l}\text { impact } \\
\text { test }\end{array}$ & $\begin{array}{l}\text { delivery of reactive } \\
\text { liquid from liquid } \\
\text { reservoir through } \\
\text { vascular networks }\end{array}$ & $\begin{array}{l}\text { forming dynamic } \\
\text { acylhydrazone bonds } \\
\text { through acidcatalyzed } \\
\text { condensation between } \\
\text { PEG and B3 }\end{array}$ & $\begin{array}{l}\text { impact } \\
\text { energy }\end{array}$ & $62 \%$ & $\mathrm{Y}$ & $\mathrm{RT}$ & $24 \mathrm{~h}$ & $\begin{array}{l}{[222,} \\
223]\end{array}$ \\
\hline
\end{tabular}




\begin{tabular}{|c|c|c|c|c|c|c|c|c|c|}
\hline $\begin{array}{l}\text { vascular } \\
\text { network in } \\
\text { polymer } \\
\text { composite }\end{array}$ & $\begin{array}{l}\text { compres } \\
\text { sion }\end{array}$ & $\begin{array}{l}\text { delivery of EPON } \\
\text { epoxy and aliphatic } \\
\text { amidoamine } \\
\text { hardener through } \\
\text { vascular network }\end{array}$ & $\begin{array}{l}\text { curing of EPON epoxy } \\
\text { by the amine hardener }\end{array}$ & $\begin{array}{l}\text { mode-I } \\
\text { fracture } \\
\text { toughness }\end{array}$ & $86 \%$ & $\mathrm{Y}$ & RT & $>24 h$ & $\begin{array}{l}{[224-} \\
231]\end{array}$ \\
\hline $\begin{array}{l}\text { layer-by-layer } \\
\text { in smart } \\
\text { coating }\end{array}$ & $\begin{array}{l}\text { puncture } \\
\text { damage }\end{array}$ & $\begin{array}{l}\text { release of UV- } \\
\text { curable epoxy }\end{array}$ & $\begin{array}{l}\text { curing of Loctite Impruv } \\
365 \text { UV-curable epoxy } \\
\text { under UV light }\end{array}$ & microscope & NM & NM & $\begin{array}{l}365 \mathrm{~nm} \\
\text { UV light }\end{array}$ & $60 s$ & [232] \\
\hline $\begin{array}{l}\text { multilayer } \\
\text { barrier film }\end{array}$ & & $\begin{array}{l}\text { release of metal } \\
\text { oxide precursor } \\
\mathrm{TiCl}_{4} \text { from PLA } \\
\text { fiber }\end{array}$ & $\begin{array}{l}\text { forming solid titanium } \\
\text { oxides due to } \mathrm{TiCl}_{4}\end{array}$ & $\begin{array}{l}\text { water vapor } \\
\text { permeability }\end{array}$ & $64.5 \%$ & NM & $\mathrm{NM}$ & $\begin{array}{l}20 \\
\text { days }\end{array}$ & [233] \\
\hline $\begin{array}{l}\text { polymer } \\
\text { composite } \\
\text { embedded } \\
\text { with solid- } \\
\text { state healing } \\
\text { agent }\end{array}$ & $\begin{array}{l}\text { Charpy } \\
\text { impact } \\
\text { test }\end{array}$ & $\begin{array}{l}\text { alignment by a liner } \\
\text { and put together } \\
\text { under pressure }\end{array}$ & $\begin{array}{l}\text { reversible hydrogen } \\
\text { bonding between solid- } \\
\text { state healing agent } \\
\text { polybisphenol-A-co- } \\
\text { epichlorohydrin }\end{array}$ & $\begin{array}{l}\text { mode-I } \\
\text { fracture } \\
\text { toughness }\end{array}$ & $>65 \%$ & $\mathrm{Y}$ & $140^{\circ} \mathrm{C}$ & $2 \mathrm{~h}$ & $\begin{array}{l}{[234-} \\
237]\end{array}$ \\
\hline $\begin{array}{l}\text { FG-TPU } \\
\text { composite }\end{array}$ & razor cut & $\begin{array}{l}\text { put together } \\
\text { manually }\end{array}$ & $\begin{array}{l}\text { interdiffusion of TPU } \\
\text { chain in the response to } \\
\text { input energy }\end{array}$ & $\begin{array}{l}\text { tensile } \\
\text { strength }\end{array}$ & $>98 \%$ & $\mathrm{Y}$ & $\begin{array}{l}\text { a) IR; b) } \\
\text { electricit } \\
y ; c) \\
\text { electroma } \\
\text { gnet } \\
\text { waves }\end{array}$ & $\begin{array}{l}\text { a) } 3-5 \\
\text { min; } \\
\text { b) } 3 \\
\text { min; } \\
\text { c) } \\
0.7-3 \\
\text { min }\end{array}$ & [238] \\
\hline $\begin{array}{l}\text { polymer } \\
\text { composite } \\
\text { embedded } \\
\text { with solid- } \\
\text { state healing } \\
\text { agent }\end{array}$ & $\begin{array}{l}\text { SENB } \\
\text { fracture } \\
\text { test }\end{array}$ & $\mathrm{NM}$ & $\begin{array}{l}\text { formation of large-scale } \\
\text { EMAA-bridging ligaments } \\
\text { along the delamination }\end{array}$ & peak load & $85 \%$ & $\mathrm{Y}$ & $150^{\circ} \mathrm{C}$ & $\begin{array}{l}30 \\
\min \end{array}$ & [239] \\
\hline
\end{tabular}




\begin{tabular}{|c|c|c|c|c|c|c|c|c|c|}
\hline $\begin{array}{l}\text { polyurethane } \\
\text { composite }\end{array}$ & $\begin{array}{l}\text { tensile } \\
\text { fracture } \\
\text { test }\end{array}$ & shape memory effect & $\begin{array}{l}\mathrm{DA} / \mathrm{rDA} \text { reaction between } \\
\text { furan and maleimide } \\
\text { moieties in the response to } \\
\text { thermal treatment }\end{array}$ & failure load & $60-85 \%$ & $\mathrm{Y}$ & $\begin{array}{l}140^{\circ} \mathrm{C} \\
\text { first then } \\
80^{\circ} \mathrm{C}\end{array}$ & $\begin{array}{l}0.5 \mathrm{~h} \\
\text { first } \\
\text { then } \\
2 \mathrm{~h}\end{array}$ & $\begin{array}{l}{[240,} \\
241]\end{array}$ \\
\hline $\begin{array}{l}\text { shape memory } \\
\text { based } \\
\text { composite }\end{array}$ & $\begin{array}{l}\text { cut by } \\
\text { sharp } \\
\text { blade }\end{array}$ & shape memory effect & $\begin{array}{l}\text { interdiffusion of healant } \\
\text { polymer chain }\end{array}$ & peak load & $>60 \%$ & $\mathrm{Y}$ & $>80 \mathrm{oC}$ & $\begin{array}{l}0.5- \\
1.5 \mathrm{~h}\end{array}$ & $\begin{array}{l}{[242-} \\
244]\end{array}$ \\
\hline
\end{tabular}

